\title{
Exploring the mission-development nexus through stories from \\ Christian 'missionaries' in Bangladesh
}

Anna Thompson

2012

A thesis submitted to Victoria University of Wellington in partial fulfilment of requirements for the degree of Master of Development Studies

School of Geography, Environment and Earth Sciences Victoria University of Wellington 



\section{Abstract}

Over the past decade, development research and policy has increasingly paid attention to religion and belief. Donors and researchers have progressively engaged with faith-based organisations and recipients. However, Christian mission and 'missionaries' remain underexplored aspects within religion and development discourses.

In response, this research explores stories from eleven Christian 'missionaries' in Bangladesh. Firstly, I assess how the changing non-governmental sector in Bangladesh influenced participants' activities. Secondly, I contextualise their stories within religion and development discourses with reference to analyses of development workers. Finally, I reflect on the significance of spirituality in participants' lives. I also describe how spirituality played a role in my research.

I frame this research within feminist and poststructuralist ways of knowing. Methodologically, I conducted semi-structured interviews and 'hung out' with participants. I 'wrote myself-in' to this research to highlight how the process intersected with my own subject positions.

I found that participants' engaged with development in similar ways to development workers as analysed by others. They reproduced discourses of modernisation, expertise, altruism, and the 'third world'. They additionally responded to Christian discourses, such as 'calling'. Participants' activities and subjectivities were shaped by these intersecting discourses, and were also shaped by the historic and current setting of Bangladesh.

Missionaries' stories revealed some aspects of the 'mission-development nexus' in Bangladesh (Fountain, 2012). Participants' stories and my own research experience, also demonstrated that engagement with belief in God can be difficult within development and within 'the academy' (Shahjahan, 2005).

\section{Key words}

Religion and development; Christian missionaries; development workers;

Bangladesh; spirituality and research. 


\section{Acknowledgments}

To the eleven generous people who agreed to be interviewed, thank you, obviously this research would not have happened without your contribution. Many thanks also to my hosts in Bangladesh for your hospitality and kindness.

I want to thank my supervisor Sara Kindon, who coached me patiently through this research, without your support this thesis would never have been completed. You are a wonderful supervisor! Thank you for your belief in me, particularly when I doubted myself so much. I would also like to acknowledge Andrew McGregor who started me on this research journey and encouraged my interest in the subject.

I want to especially acknowledge my flatmates, Colleen, Olivia, Kathryn, Julian, Warrick, Javier, Emily, Bronwyn, Brendan, Philippa, Emma, and Neal, and also the wider Stillwaters community who are another kind of family. I would not have completed this work without your support and kindness. Particular thanks to Bronwyn and Emma who engaged with my questions and debates, pushed me to think more clearly about what I said, sympathised, and most of all made me laugh. Emma, thank you also for the hours you spent proofreading and delicately suggesting changes. Special thanks also to Emily who picked up all my flat duties and supplied me with essential quantities of chocolate.

This research comes from family. I want to acknowledge the wonderful heritage that my family have given me. My grandparents and great grandparents, for their convictions and adventures. My siblings, Emily, Philippa and Daniel, who are also my best friends, constant partners in adventure and argument, I love you three more than I can say. My parents, Adrienne and Paul, who still teach me how to be critical and loving, generous and kind. I strive to live up to your example. Thank you always.

This research has revolved around the life and death of my very greatly loved niece, Hope. I want to dedicate this thesis to Hope. I somehow finished despite all the afternoons taken off to read stories, dress-up, dance round the living room, bake cakes or run down the hill to the playground, the zoo or te Papa.

For Hope. I miss you. 


\section{Table of Contents}

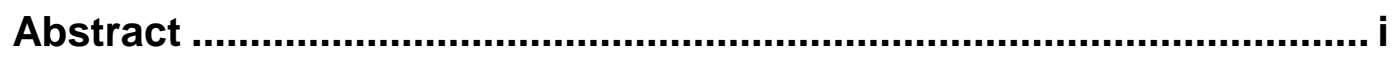

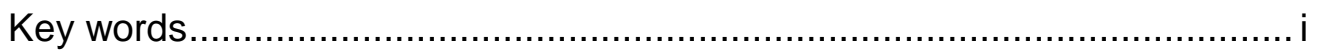

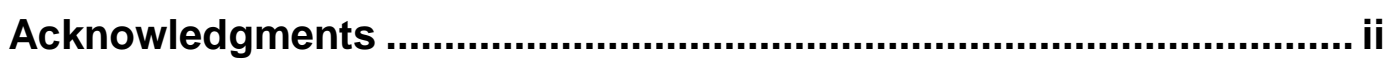

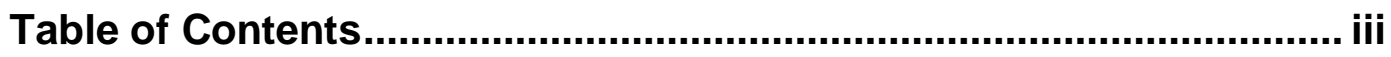

List of Tables and Figures ......................................................................

Glossary of terms and acronyms .............................................................. vi

Bible translation.........................................................................................

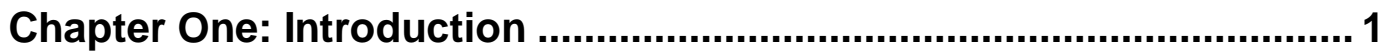

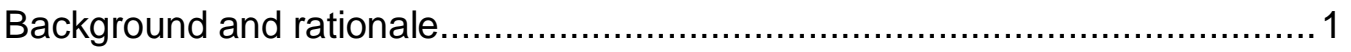

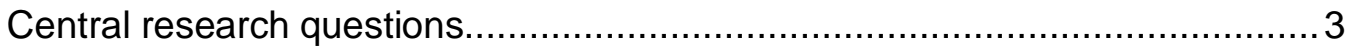

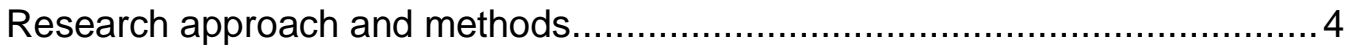

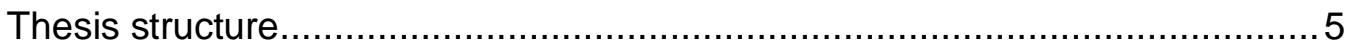

Chapter two: Religion in development and the people who do

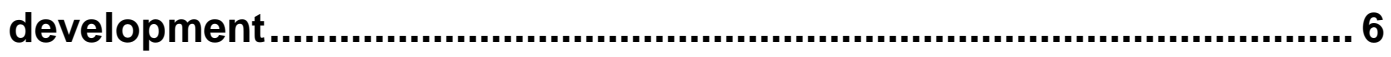

Part one: Religion and Development .................................................... 6

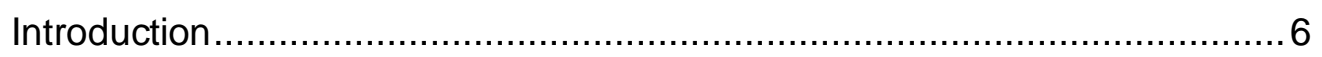

Historical relationship between religion and development ......................... 7

Religion as instrumental............................................................... 10

Faith-based organisations......................................................... 12

Mission as the 'invisible' NGO......................................................... 14

Engaging with the transcendental .................................................. 15

Summary of religion in development ................................................. 15

Part two: The development of an aid worker............................................. 16

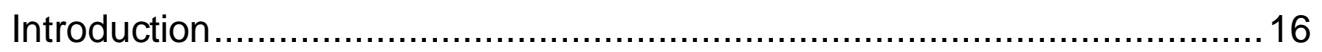

Who are development workers? ....................................................... 17

Agents of development: identity shapes aid ............................................. 18

The development expert .............................................................. 18

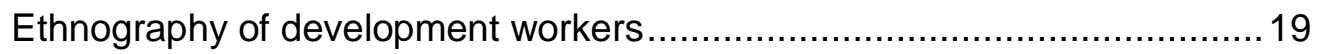

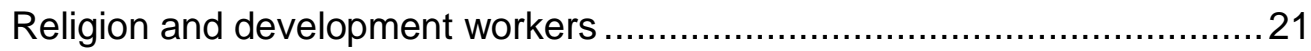

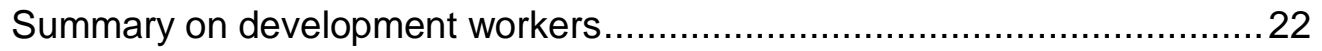

Part three: Religious development workers ..............................................23

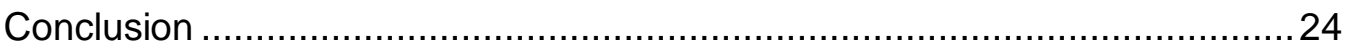

Chapter three: Research Approach .................................................. 26 


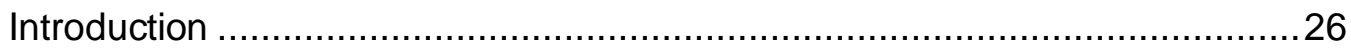

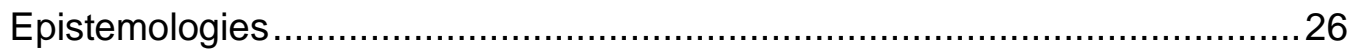

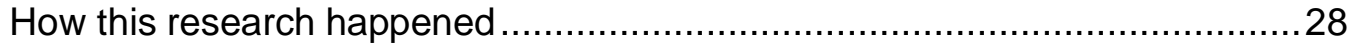

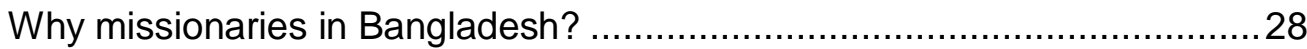

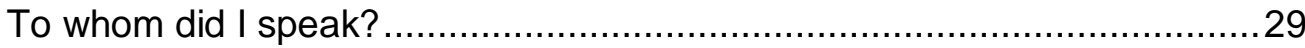

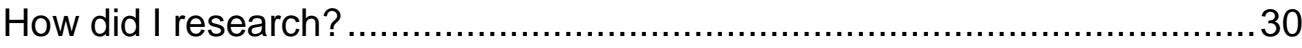

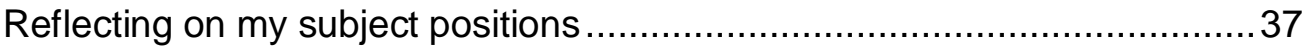

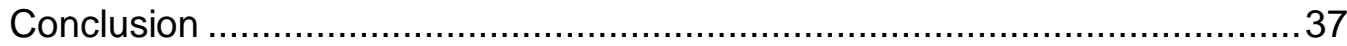

Chapter Four: Christian mission and Bangladesh ............................38

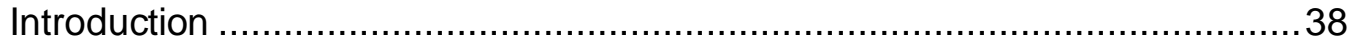

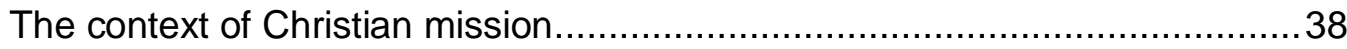

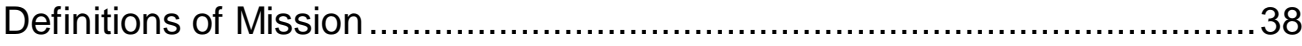

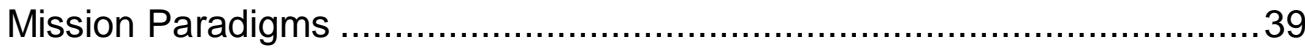

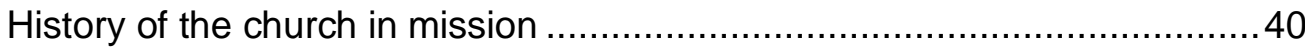

The Enlightenment, Colonialism, and Mission.......................................... 41

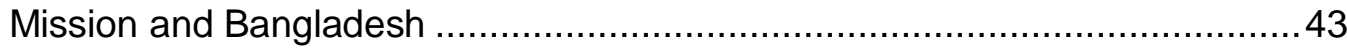

The non-government sector in Bangladesh............................................46

Current Christian mission in Bangladesh ...............................................49

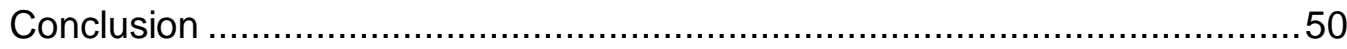

Chapter five: Participants' stories .................................................52

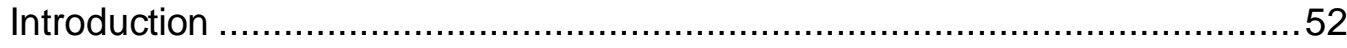

Who were the participants and what did they do?........................................ 53

Participants' motivations: why are they in Bangladesh? ...............................56

Origins of the missionary and the development worker ...........................56

'Called' by God to Bangladesh..........................................................5

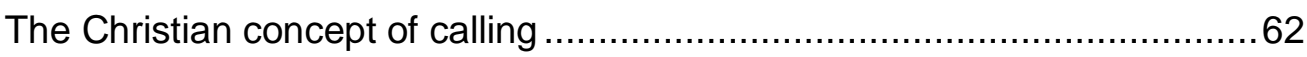

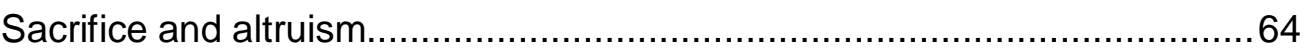

Participants' activities - what did they do in Bangladesh? ...........................66

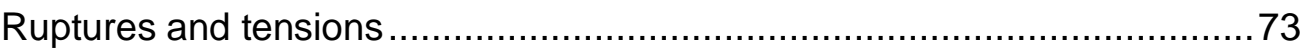

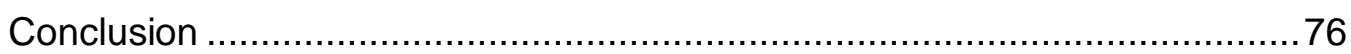

Chapter six: Reflections and conclusion .........................................77

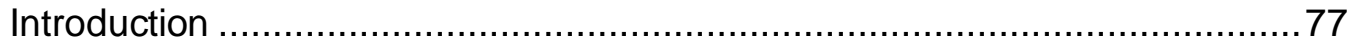

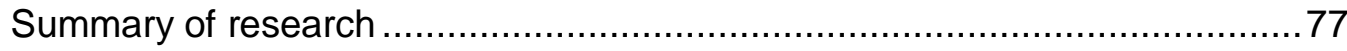

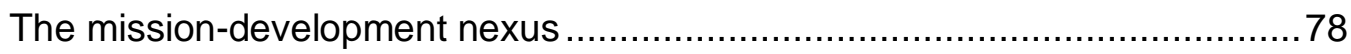

Participants' stories and the Mission-development nexus ........................78 
Place matters

Reflections on the research process ................................................... 80

Trying to bring things back together: Centring spirituality in development and research

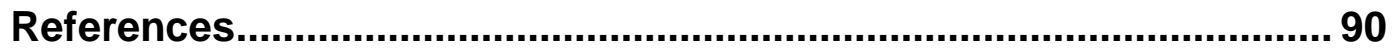

Appendices.................................................................................... 109

\section{List of Tables and Figures}

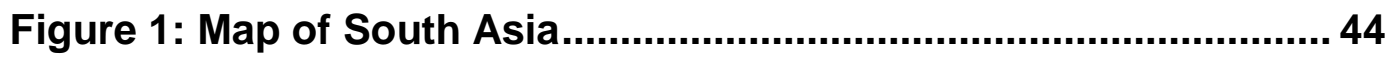

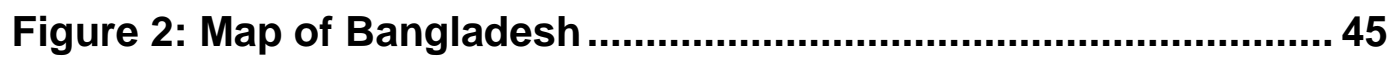

Table 1: Facets of participants' subjectivities................................... 53 


\section{Glossary of terms and acronyms}

Awami League One of two key political parties in Bangladesh. Also significant in the independence movement.

Bideshi A foreigner in Bangladesh, usually white/western. Literal translation is not Bangladeshi, desh $=$ land/country.

BNP Bangladesh National Party. One of two key political parties in Bangladesh. Significant players in the independence movement.

FBDO Faith-Based Development Organisation.

FBO Faith-Based Organisation.

NGO Non-Governmental Organisation.

Ragas A type and method of classical music in India and Bangladesh.

RNGO Religious Non-Governmental Organisation.

Tabla Bangladeshi drums.

Tagore, Rabindranath 1861-1941, renown Bengali poet, lyricist, writer, social activist and independence campaigner, and writer of Bangladesh's national anthem, Amar Shonar Bangla (My Golden Bengal). 


\section{Bible translation}

All biblical references are from The Message translation unless otherwise stated.

All references were retrieved from http://www.Biblegateway.com/. 


\section{Chapter One: Introduction}

\section{Background and rationale}

This research is about the mission-development nexus in Bangladesh. I consider how aspects of belief/faith in stories from eleven Christian 'missionaries' in Bangladesh may contribute to understanding dimensions of this nexus:

- the evolving debates concerning the significance, role and practice of incorporating religion into 'development'

- the people who 'do' mission, and those who 'do' development, specifically Christian missionaries, their role and history in 'development', and my personal connection to this role and history

- the location of religion/belief/faith ${ }^{1}$ in research and in development

Recent debates in development studies have criticised mainstream secular perceptions of religion in development, specifically that religion is a hindrance to development; an aspect of culture that will decline as countries modernise (secularisation thesis); or an instrument to better development outcomes. Instead it has been noted that religious beliefs may play a role in development outcomes (Tyndale, 2006; Ver Beek, 2000) and may be an instrument to achieve 'better' development outcomes than secular interventions (Jones \& Petersen, 2011). It has also been argued that an holistic approach to development requires genuinely recognising the value of spiritual beliefs in people's lives (Deneulin \& Bano, 2009; Ter Haar, 2011; Tyndale, 2006; Ver Beek, 2000 among others).

I began this research by looking at religion and development debates. ${ }^{2}$ I was interested in how faith/belief/religion was responded to, contributed to and was incorporated into development. My interest in this area of religion and development arose from personal experiences of religion in Bangladesh. I have a

\footnotetext{
${ }^{1}$ Religion, faith and belief are not the same and I do not at any point wish to imply that they are. They are, however, hard to define (Shahjahan, 2005). I write religion/faith/belief because I want to encompass formalised 'religious' institutions and followers and also consider less formal belief and faith. Faith and belief are also different attributes, Julie Laible (2000, p. 684). Throughout this thesis I have referred to belief/faith and sometimes religion interchangeably. I realise that there are variations between the three but I wish to incorporate the breadth of all three. I have referred also to 'spirituality' to encompass religion, faith, and belief, though again recognise the flaws in this approach.

${ }^{2}$ I refer in this thesis repeatedly to 'religion and development' debates and literature. This is not a bounded body of work but rather one that is continually being added to. I use this term for the purposes of manageability throughout this thesis.
} 
long missionary heritage. I am the child, grandchild, great-grandchild, and greatgreat-grandchild (maternal and paternal) of white/pākehā Aotearoa New Zealand Baptist missionaries in Asia (China, Bangladesh, and India), and Africa (Egypt, Eretria and Ethiopia).

Very broadly, Christian mission is a deliberate expression of Christian belief for a specific purpose (frequently the propagation of this belief). Mission is integral to Christian faith (Kim, 2010; Wright, 2006). A missionary can be defined as

someone (lay or ordained) commissioned to a particular task generally overseas or to a different community - of specifically Christian ministry or more general humanitarian work. Often missionaries are part of a missionary society or religious order, or they may be sent out by a local church or denominational board of mission. Missionaries may or may not be clergy; they may receive a stipend from their home church or be self-supporting (Kim, 2007, p. 3/4)

This definition is extremely broad and reflects the variation in missionaries as a heterogeneous group of actors. Often Christian missionaries participate in a wide range of activities including social service provision and social action (Deneulin \& Bano, 2009; Kim, 2010). In addition, like the term 'development', 'mission' is often poorly defined or articulated (Balchin, 2007). However as Fountain notes,

the relationship between concepts like 'mission' and 'development' is ... always-already open to metamorphosis and should be seen as dynamic, fluid, contingent and constantly remade by the actors involved (Fountain, 2012, p. 152).

Mission theologies and activities are contested by Christian believers, including participants in this study who also questioned the term 'missionary'. ${ }^{3}$ This research is situated within the spaces between and across mission and development as experienced by 'missionaries' in Bangladesh.

Given my past experiences, I was interested in the apparent absence of discussion about Christian missionaries in the growing literature on religion and development. I knew that my parents had been involved in, among other activities, disaster relief, education, and cottage industries as missionaries in Bangladesh. These activities are often considered the realm of development nongovernmental organisations (NGOs), government agencies and multi-and

\footnotetext{
${ }^{3}$ I continue to use the word 'missionary' throughout this research; however, I supplement my analysis by discussing 'religiously motivated actors'. I emphasise that 'missionary subject positions' are far from fixed, and to reflect this in my analysis.
} 
bilateral development initiatives. I also knew that my parents did not describe what they did as 'development' or themselves as 'development workers'. Additionally I was aware of theological debates in mainstream evangelical protestant churches which advocated increasing the church's role in poverty alleviation, social justice, and 'development'. ${ }^{4}$ These theological shifts are sometimes presented as 'holistic mission'; a mission approach which incorporated spiritual and physical change (Hoek \& Thacker, 2008). As I saw it missionaries were already involved in development, and missionaries, mission organisations and institutional church organisations were looking to increase that engagement. Consequently I decided to make Christian missionaries in Bangladesh the topic of my research.

I found that just as religion has been a neglected subject in 'development' research, so too have people working in development contexts been largely under-analysed. Furthermore, I found that where research does examine development workers, it often neglects how belief/faith can complicate the motives and activities of these people (be they missionaries or 'development workers') (Cook, 2007; Eriksson Baaz, 2005; Heron, 2007).

Finally I also found that the spaces in which spirituality is discussed within the 'academy' are very restricted. It was my aim to 'write myself in' to the research, however I struggled to include ways in which my beliefs' were part of this research.

\section{Central research questions}

Engaging with the three broad points of interest above (religion and development, people who 'do' development, and the location of belief/faith in development and in research) I wanted to know:

1. What are the stories some missionaries in Bangladesh tell about mission; their motivations, aims, and practices?

\footnotetext{
4 Other church denominations have also been concerned with this (many never stopped incorporating these issues into belief practices). I refer here specifically to changes I was aware of through my background in evangelical, namely Baptist, churches.

${ }^{5}$ Riyad Shahjahan and Kimberly Haverkos, writing about spirituality and academic research, refer to the Academy to describe universities and colleges in order to "situate our discussion in the context of the 'highest' centers of learning located in the West" (2011, p. 367)
} 
2. How can aspects of belief/faith/religion in these missionaries' stories and actions inform understandings about the mission-development nexus?

3. How can belief/faith/religion be better acknowledged in development and in research?

From this my key objectives became:

1. To listen to and analyse the multiple, complex, and intersecting stories that some missionaries told about themselves and their work (and to situate myself in this analysis).

2. To explore, through these stories, the connections and disconnections between 'mission' and 'development' to further understand this relationship, and to reflect on wider debates concerning 'religion and development' and the people who 'do' development.

3. To question ways in which faith/belief/religion are already part of research and development and to consider ways of centring spirituality in future work and allied areas.

\section{Research approach and methods}

In my research approach I listened to participants' stories about what they did, and reflected on these stories. I also tried to write myself in to my discussions and analysis in recognition that as a researcher I construct "a particular and partial story" (Mansvelt \& Berg, 2010, p. 343). In this orientation I am influenced by feminist and poststructuralist epistemologies. I used semi-structured interviews and participant observation. I recorded my observations and reflections in a journal. My analysis linked missionaries' stories to analyses of development workers. I also connected to wider discourses of Christian 'mission' and 'development'. Interweaving this discussion I reflected on the role of spirituality and belief in research and in 'development'. Writing myself into this research I want to acknowledge my complicity in the issues discussed and that this exploration is tentative, limited, and open to contestation. I present only one way in which this group of missionaries' stories can be interpreted. 


\section{Thesis structure}

Following this introduction I present the relevant literature. I lay out the broader religion and development debates. I identify how faith/belief/religion has been responded to in development literature, providing a rationale for my research. I also introduce some of the research examining 'development workers'. These debates establish the context and gaps addressed by my work.

In chapter three I describe my approach to research and the activities I undertook during this research process, namely semi-structured interviews and participant observation. I describe how I came to speak with participants and how I analysed what they said. I also raise some of the ethical considerations I experienced.

In chapter four I introduce the contexts in which this research is placed. I first identify some historic and current paradigms of Christian mission. I then describe the environment in which current missionary practices were formed, namely colonialism and the European Enlightenment. I also situate Christian missionaries in the context of Bangladesh and describe the changing NGO framework in which many missionaries in Bangladesh operate. This context sets the scene for the analysis of some specific missionary narratives in the following chapter.

In chapter five I discuss participants' stories within wider contexts of development, colonialism, and mission. I link their stories to existing analyses of secular development workers (particularly Heron, 2007) to highlight their similarities and differences. I consider particularly stories about 'calling' and 'sharing' and analyse how these stores are situated in multiple intersecting discourses.

In chapter six I consider three significant aspects of this research. I reflect further on participants' stories and note how their experiences informed the missiondevelopment nexus. I then consider how the context of Bangladesh informed how and where mission-development occurs. Finally I discuss the difficult place that spirituality occupies in development research and practice. I conclude with some suggestions for further research on the mission-development nexus. 


\section{Chapter two: Religion in development and the people who do development}

In this chapter I explore the way religion has been discussed in development literature, and argue that in this literature Christian missionaries have been overlooked. I then review some of the literature about development workers. Examining this literature provides insights into some of what 'missionaries' do and their reasons for doing so, along with their effects. In the absence of similar studies on missionaries' practices, this body of work provides a basis for later comparative analysis between participants and secular development workers.

\section{Part one: Religion and Development}

Development specialists are "one-eyed giants ... they analyse, proscribe and act as if man [sic] could live by bread alone, as if human destiny could be stripped to its material dimensions alone (Goulet, 1980, p. 481).

\section{Introduction}

Until recently religion was largely ignored as a significant factor in development. Governments and international donors focussed primarily on economic growth and modernisation which would follow a 'western' trajectory. The disregard of religion occurred despite the beliefs of people within 'developing countries' and in spite of the historically-close associations between Christianity and empire, and between religion and social charity (Manji \& O'Coill, 2002; Tvedt, 1998). ${ }^{6}$ The neglect of religion was evident in institutions and governments (Marshall \& Keough, 2004), NGOs (Ver Beek, 2000), and in research (Lunn, 2009; Ver Beek, 2000).

A number of books and articles have begun to address this gap. In 1980 the journal World Development dedicated one issue to questions of religion and development. More recently the journal Development dedicated an issue to the theme of religion and development (Volume 46, Issue 4, 2003) and a recent edition of Development in Practice also concentrates on religion and development (Volume 22, Issue 5-6, 2012). Research has addressed the role of faith, religious institutions, and faith-based development (G. Clarke \& Jennings,

\footnotetext{
${ }^{6}$ Many NGOs have links to religious groups or institutions, and many mission organisations became development organisations in this period. For example Terje Tvedt has traced the changes within the Norwegian Mission (Tvedt, 1998, pp. 140-150). See also Manji and O'Coill (2002).
} 
2008; M. Clarke, 2012; Deneulin \& Bano, 2009; Haynes, 2007; Salemink, Van Harskamp, \& Giri, 2004; Ter Haar, 2011; Tyndale, 2006; Ver Beek, 2000).

Research on faith and development has examined institutions and organisations such as: NGOs (Benedetti, 2006; G. Clarke, 2006); multi-and bi-lateral agencies (Marshall \& Keough, 2004; D. Narayan, Chambers, Shah, \& Petesch, 2000; D. Narayan, Patel, Shchafft, Rademacher, \& Koch-Schulte, 2000; D. Narayan \& Petesch, 2001); Governments (G. Clarke, 2007); and church institutions (McGregor, Skeaff, \& Bevan, 2012). The intersection between religion and development is further examined through projects and outcomes (Tyndale, 2006), and recipients (De Cordier, 2009; Ter Haar \& Ellis, 2006; Tripp, 1999; Ver Beek, 2000; B. Walker, 1999).

Religion has also entered into the priorities and language of mainstream secular development organisations such as the United Nations Children's Fund (United Nations Children's Fund, 2012) and the United Nations Populations Fund (United Nations Populations Fund, 2009), government donors such as the Canadian International Development Agency (CIDA) (Canadian International Development Agency, 1995; see also Tripp, 1999), the Department for International Development (DfID) (Deneulin \& Rakodi, 2011; Department for International Development, 2012), and multilateral donors such as the World Bank. ${ }^{7}$ As a result, faith-based organisations (FBOs) and religious non-governmental organisations (RNGOs) are increasingly examined. While many researchers and development practitioners now acknowledge the importance of holistic development (including spirituality), within this context Christian missionaries are largely absent from the discussions.

\section{Historical relationship between religion and development}

In the emerging development environment following World War II, two paradigms dominated the approach to religion. These were a) that religion was a hindrance to development; and b) that religion was irrelevant to development (Deneulin \& Rakodi, 2011; Jones \& Petersen, 2011; Tomalin, 2012).

\footnotetext{
7 The World Bank has engaged with faith and development through involvement with the World Faith and Development Dialogue (WFDD) (Wolfensohn \& Carey, 2001). For more on the World Bank and dialogue with faith-based organisations see also Faith and Development: Partnership between the World Bank and the churches of Africa (Belshaw, Calderisi, \& Sugden, 2001) and Mind, heart and soul in the fight against poverty, (Marshall \& Keough, 2004).
} 
After World War II an almost exclusive focus on economic outcomes dominated development intervention. In this context "religion [was] noted as an element of 'culture', often impeding development” (Selinger, 2004, p. 525). Religious beliefs were seen as fostering a restrictive view of the world. Religion was felt to be "counter to development" (G. Clarke, 2007, p. 79). Often underlying this attitude was a belief that only some religions are counter to development, while economic growth was thought to depend on "certain attitudes towards variables" (Deneulin \& Bano, 2009, p. 31). The Protestant work ethic was widely propagated as the reason for the success of the European/American development model (Deneulin \& Rakodi, 2011, p. 46; Weber, 1993).

Often building on the conceptualisation of religion as a hindrance to development has been the argument that religion is irrelevant. It was thought that as countries 'modernised' they would also secularise (Deneulin \& Bano, 2009, p. 53; see also Herbert, 2003, p. 57; B. R. Wilson, 1982). ${ }^{8}$ Furthermore, it was assumed that religious belief should be a private matter and therefore out of the public realm (Hovland, 2008). It is argued by some that this secularisation approach resulted in an 'uneasy' relationship between religion and development (Jones \& Petersen, 2011, p. 1292; Selinger, 2004).

The secularisation thesis has been rejected by many social scientists, not least because of the obvious failure of its predictions (Deneulin \& Bano, 2009). Far from disappearing, there is recognition of the on-going significance of religion (Haynes, 2007; Tomalin, 2012; White, 2012). In addition the assumption that development and modernisation inherently entails a reduction in 'non-scientific' beliefs has been called condescending, holding "the silent conviction that science and development ultimately will allow people to leave behind their spiritual and 'unscientific' beliefs" (Ver Beek, 2000, p. 39).

The theory of secularisation has been further critiqued for assuming that secular development is value-free. In contrast value-free secular development has been criticised as a "myth" (Editorial, 1999, p. 5), containing "coercive utopias" (Ter Haar \& Ellis, 2006, p. 354), and also imposing beliefs (McGregor, 2010). In

\footnotetext{
${ }^{8}$ See also G. Clarke (2007) and Lunn (2009) for further commentary on this secularisation thesis.
} 
addition it has been argued that secularism as found in European/North American modernity is not entirely free of 'magical' elements (Hovland, 2008, p. 172). ${ }^{9}$

The absence of religion in development began to change during neo-liberal economic restructuring throughout the 1980 s and 1990 s. ${ }^{10}$ During this time nongovernmental organisations, including FBOs, became significant deliverers of services (G. Clarke, 2008; Hearn, 2002; Manji \& O'Coill, 2002). ${ }^{11}$ Consequently many RNGOs were integrated into mainstream development practice (G. Clarke \& Jennings, 2008; Hearn, 2002). More recently the perceived rise of religious extremism, particularly after 11 September 2001, has contributed to a renewed focus on the importance of religion and the necessity of partnering with religious NGOs for more effective aid delivery and security (G. Clarke, 2008; Haynes, 2007). As a result religion has been included in governmental and bi- and multilateral development policy, such as the World Bank report Voices of the Poor (1999; 2000; 2001) which recognised the significant role religion plays in poor peoples' lives. ${ }^{12}$ Gerard Clarke, says that faith-based organisations

can be a potent force in the lives of the poor where they focus on material as well as spiritual poverty, avoid divisive or sectarian agendas, and become more involved in the daily struggles of the faithful (G. Clarke, 2007, p. 80).

Thus political changes led to a reassessment and integration of religious NGOs into development.

In addition to political and economic drivers, sociocultural factors encouraged the incorporation of religion into development. The increasing significance placed on faith and faith-based organisations may lie in the emergence of a postmodern era, which included a reaction against secularism, and the rise of religion (in

\footnotetext{
9 Ingie Hovland writes that secularism in Europe is "deeply rooted and intertwined in religious formations" (2008, p. 172). Secularism in Europe and other 'western democracies' is not the opposite of religion, but was formed through religious, political and social changes in Europe over the Enlightenment period (Hovland, 2008, pp. 171-172). See also Asad (2003) and Meyer and Pels (2003).

10 Restructuring placed emphasis on market liberalisation and reduced government control. Restructuring was driven by mainly politically-right wing governments in the Global North and implemented through organisations such as the International Monetary Fund and the World Bank.

${ }_{11}$ Gerard Clarke links the interest in 'faith and development' to the rise of the Christian right (particularly in government) in America following the election of Ronald Reagan in 1980, the neoliberal economic policies of the Reagan government, the rise of political Islam beginning with the Iranian revolution in 1979, the decline of communism and the accompanying 'rise of identity politics', the rise of 'transnational civil society, and increasing immigration (G. Clarke, 2008, pp. 1924).

${ }_{12}$ See particularly, Voices of the Poor: Crying out for Change, "spirituality, faith in God and connecting to the sacred in nature are an integral part of poor people's lives in many parts of the world" (D. Narayan, Chambers, et al., 2000, p. 222).
} 
social movements and civic cultures) (Selinger, 2004). Leah Selinger (2004) argued that far from declining or moving entirely to the private sphere, religion has become more prominent. She also advocated that religion be brought back into discussions on society/culture, as it plays an integral part in shaping economic outcomes (Selinger, 2004; see also Deneulin \& Bano, 2009; Haynes, 2007). Jeffery Haynes has additionally argued that

deepening globalisation, pervasive calls for better governance and widespread religious resurgence ... have encouraged the belief that religion can play an important role in the achievement of desirable development outcomes (Haynes, 2007, p. 2).

Such reassessments of the role of religion in development has led various scholars to assert that some of the failures of development can be explained in "the absence of the recognition of culture, and more specifically religion in development theory and practice" (Selinger, 2004, p. 524; see also G. Clarke, 2007; G. Clarke \& Jennings, 2008; Haynes, 2007; Ver Beek, 2000). Kurt Ver Beek has argued that not only does the absence of religion explain development deficiencies but that

the failure to provide spaces for people to understand and explore, and ultimately to determine how development programmes should and will affect their spirituality, and in turn their society, is antidevelopmental (Ver Beek, 2000, p. 32).

These evaluations led to a review of the relevance of religion and spirituality to development outcomes and practice. Some scholars and development practitioners have argued that religion should be incorporated into development as an instrument to improve development programmes and outcomes (Jones \& Petersen, 2011).

\section{Religion as instrumental}

Rather than seen as a hindrance or irrelevant, some authors argue that spiritual beliefs should be included in project planning because doing so produces 'better' development outcomes (Tyndale, 2003, 2006; Ver Beek, 2000). The 'positive' and 'negative' impacts on development outcomes arising from religious beliefs have also been noted (Bradley, 2009; Haynes, 2007). RNGOs and FBOs are increasingly recognised as major service providers and players in development (G. Clarke, 2007; G. Clarke \& Jennings, 2008; de Kadt, 2009). FBO development initiatives benefit from global networks, both in regard to their ability to motivate 
people in the North and South and in their commitment to long term programmes and relationships (Jones \& Petersen, 2011). In addition FBOs are often highly trusted by recipients of aid and development throughout the world (G. Clarke, 2007; Marshall \& Keough, 2004; Tyndale, 2006). The potential of these organisations to participate in more relevant and effective development than secular development, with higher levels of recipient ownership has been noted (Hearn, 2002; Tyndale, 2003, 2006). However, RNGOs have also been critiqued on these issues and practitioners, donors, and policy makers are cautioned on using RNGOs too widely without due consideration (Balchin, 2007; Bradley, 2005; de Kadt, 2009).

The perception that FBOs can deliver more effective and efficient aid, while valid in some cases, nevertheless places the role of faith as instrumental to development (Jones \& Petersen, 2011). Thus faith plays a role within the traditional economic focus of development. Religion is seen as either an impediment to economic growth or an instrument to foster greater commitment to development projects (often with largely economic objectives). Furthermore, critics have argued that "privileging the role of religious organisations in servicedelivery .... serves a neoliberal privatisation agenda" (Balchin, 2011, p. 18).

It has been argued instead that 'holistic development' requires recognising the inherent value and importance of spiritual beliefs (Deneulin \& Bano, 2009; Ter Haar \& Ellis, 2006; Tyndale, 2003, 2006; Ver Beek, 2000). Others contend that religion should not be

considered only as a significant force in development ... but has to be engaged with in its entirety and not only to the extent that is conducive or detrimental to pre-defined development goals (Deneulin \& Bano, 2009, p. 6).

Gerrie Ter Haar and Stephen Ellis argue that while development workers and institutions should consider how aspects of religion can be adapted for development purposes, spirituality should also be affirmed for its own value (2006, p. 360/363). This approach is in line with post-development critiques and alternative development approaches which argue that spirituality is a neglected aspect of development and that true development must take account of the whole person, spiritual, mental, and physical (Rahnema, 1997). 
Critics of the secular separation of religion in development have also noted the ways in which development is already implicated in "the politics of transcendence" (Fountain, 2012, p. 145; see also Buijs, 2004; Hovland, 2008; Salemink et al., 2004). Furthermore, Philip Fountain argued that the "disciplining and re-construction of religion" is itself 'a religious intervention', and may serve to conceal the eschatological and proselytising nature of development (2012, $\mathrm{p}$. 145; Parfitt, 2009). Additionally, it has been noted that there is significant 'religious' motivation in development interventions (Fountain, 2012; Parfitt, 2009; Salemink et al., 2004). ${ }^{13}$

Séverine Deneulin and Masooda Bano argue that engagement with religion in development should acknowledge "the transcendental nature of religion" (Deneulin \& Rakodi, 2011, p.52). They write

a difficulty for the social sciences in studying religion is that of the transcendental nature of the conception of the good to which religious traditions adhere. The Christian and Muslim traditions believe that there is a higher reality, which transcends earthly human realities. This entails that the earthly life is not absolute for the believer, for s/he will find fullness of life in sharing the life of God/Allah after death. ... This transcendental understanding of the good, and of what a good life in society may be, is a source of potential conflict with the secular tradition which rules out such transcendental understanding (Deneulin \& Bano, 2009, p. 129). ${ }^{14}$

However, negotiating 'the transcendental' is recognised to be difficult. Attempts to understand how the transcendental and the secular can be reflected in development has led to a greater exploration of FBOs.

\section{Faith-based organisations ${ }^{15}$}

In light of these critiques the role and importance of faith-based Development Organisations (FBDOs) and Religious Non-governmental Organisations (RNGOs) has come under scrutiny. While there have been several attempts to categorise FBOs I use Julia Berger's definition of an RNGO or FBDO as an organisation "whose identity and mission are self-consciously derived from the teachings of one or more religious or spiritual traditions" and who then act to

\footnotetext{
13 Raymond Apthorpe (2012, p. 199) describes the UN development goals as a "secularinspirational sort of 'ten commandments'".

${ }^{14}$ When I discuss transcendental throughout this research I am engaging with this "belief in a higher reality'.

${ }^{15}$ For the purposes of simplicity I have referred primarily to FBOs, I have used this to encompass RNGOs and FBDOs in order to acknowledge that faith-based organisations and groups active in development may not define themselves as an NGO and may not define what they are doing as 'development'.
} 
realise this mission (Berger, 2003, p. 16; see also G. Clarke, 2006; G. Clarke, 2007; S. R. Smith \& Sosin, 2001).

Gerard Clarke has further categorised faith-based organisations into five groups with four accompanying attributes (active, passive, persuasive, and exclusive). ${ }^{16}$ Clarke's categories of FBOs are as follows: representative organisations or apex bodies which are described as largely passive or active; development and charitable organisations, also mostly passive or active; missionary organisations-largely active or persuasive producing conflicts for secular donors; socio-political organisations which can be persuasive and exclusive; and radical, illegal or terrorist organisations which are generally persuasive and exclusive (2008, pp. 25-39). While the first two categories have played considerable roles in development, the third category, missionary organisations, has had a mixed engagement. The two final categories are the most unfamiliar in development practice and research but may be extremely active.

Clarke argues that the challenge for donors is to engage with a range of "faith discourses and organizations" (2006, p. 846) and that failure to do so in the past has alienated intended development recipients. ${ }^{17}$ Similarly Emma Tomalin (2012) argues that FBOs can be very broadly defined and should be engaged with as such, restricting engagement to registered faith aligned charities excludes many groups of people who may already be engaging in development in some capacity. ${ }^{18}$ Recognising this fluidity in categories I now examine Christian mission organisations. Christian mission organisations are not necessarily NGOs (though some are) but at times they act in similar ways and in similar spaces to NGOs.

\footnotetext{
${ }^{16}$ Gerard Clarke (2008, pp. 32-33) defines these as passive, "the teachings of the faith ... are subsidiary to broader humanitarian principles"; active, "[faith] plays a direct role in identifying, helping or working with beneficiaries and partners, although there is no overt discrimination against non-believers"; persuasive, "faith provides an important and explicit motivation for action and in mobilizing staff and supporters .... It aims to bring new converts to the faith ... and/or to advance the interests of the faith"; exclusive, "faith provides the principle or sole consideration in identifying beneficiaries. Social and political engagement is rooted in faith ... and is often militant or violent". He discusses how different faith-based organisations can be described in these ways. Currently government and bi-and multilateral donors are more likely to work with passive and active organisations.

17 In contrast Cassandra Balchin says that there is currently too much of the 'f-word' [faith] and not enough of the 's-word' [secular] (Balchin, 2007).

${ }_{18}$ In my own research it was seen that while these categories were evident in faith-based development occurring in Bangladesh, individuals within categories were fluid with their selfdefinitions. An individual could be simultaneously a member of an apex or organisational body, part of a missionary organisation, and be employed by a faith-based NGO.
} 


\section{Mission as the 'invisible' NGO}

Missionaries do not fit comfortably into the categories outlined above within religion and development discourse. Missionaries do not use religion instrumentally, (although they may use 'development' thus). Nor do they adhere to secularisation and the redundancy of religious belief, though their approaches to belief and missionary practice have often been strongly influenced by the same processes of modernisation and the Enlightenment.

Christian mission within development literature and discourse has had a mixed history. Christian missionaries are commonly accredited with initiating many of the activities now associated with development, such as providing health care and education to marginalised groups (G. Clarke, 2008; Ter Haar \& Ellis, 2006). Often missionaries and Christian mission are spoken of as something that happened in the past, which, if still continuing, is definitely declining. However Terje Tvedt argues that "mission organisations often constitute an important part of the NGO landscape in both donor and developing countries" (1998, p. 140). ${ }^{19}$ Mission organisations are, however, infrequently examined by secular researchers, except in historical, often postcolonial analysis.

Nonetheless there is growing acknowledgement that mission organisations and 'missionaries' continue to play a significant role in the delivery of aid and development. Missionary organisations are more active now than ever before, have more money, and are increasing in numbers (Bonk, 2006). ${ }^{20}$ Despite common perception

missionary organisations remain important actors in development contexts, as providers of social services and as witnesses to the struggles of the poor. Often they are closer to the poor than development NGOs, because they maintain long-term presence in local communities and live modestly, sharing in privations that afflict the poor (G. Clarke, 2008, p. 37, see also Tyndale, 2006). ${ }^{21}$

In spite of increasing numbers mission organisations have been called the 'invisible NGO' (Hearn, 2002) and a 'donor blindspot' (G. Clarke, 2008).

\footnotetext{
${ }^{19}$ Tvedt argues that this "narrow perspective reduces the heterogeneity of the field, and makes it less easy to analyse the impact of NGOs in a longer historical perspective" (1998, p. 140).

${ }^{20}$ Between 1900 and 1994 the number of foreign missionaries globally increased from 62,000 to 320,000 (Hearn, 2002, p. 37; see also Bonk, 2006). In 2001 the estimated donations to protestant evangelical missions was $\$ 3.75$ billion (G. Clarke, 2007).

${ }^{21}$ This is strongly criticised by Bonk (2006) who writes that evangelical American missionaries are too affluent and this brings distance and ineffective mission. Likewise Tamsin Bradley (2005) critiques faith-based organisations claims of 'closeness'. See also Green, Mercer, and Mesaki (2012).
} 
Little is understood or known about these Christian missionaries and organisations. While missionaries are infrequently recognised as development actors this does not

prevent them from practicing their own visions of development, in fact ... it frees them to pursue whatever development goals they like, as they escape the gaze and disciplining technologies of the development industry that would otherwise limit their colonising behaviours (McGregor, 2008, p.180).

\section{Engaging with the transcendental}

Missionaries are actively engaged with the 'transcendental' in development, thus giving their development an arguably 'holistic approach'. Conversely they are, potentially, also actively undermining the local beliefs in their conversionary aims. Ingie Hovland says that when it comes to secular funding this produces a schizophrenic mode in mission (2008, p. 180; see also Fountain, 2012). On one side missionary agencies argue that they provide added value to development projects because of their religious difference, and on the other they must exclude their religious values in order to receive secular funding (Hovland, 2008). This is a problematic contribution to the religion and development debate where "the only legitimate development approach is one which is based on the underlying social concerns and values within a particular society" (Deneulin \& Bano, 2009, p. 46). Missionaries are able to incorporate transcendental belief in their development goals in a way that many secular organisations struggle with, but they may also be deliberately attempting to undermine existing religious beliefs.

Conversion is far from the legitimate development approach argued for by Deneulin and Bano (2009). However engagement with belief in God is far from simple. In the past secular engagement with the transcendental has often responded to religion as an unchanging belief system or culture (Buijs, 2004). To the contrary, religion, belief, spirituality, and faith practices are never static. They constantly change within the context of the society in which they are practiced, both in reaction and conservation (Deneulin \& Bano, 2009, pp. 105-106).

\section{Summary of religion in development}

In this section I provided a brief overview of the ways in which religion has been engaged with in development. That is, as an irrelevance, as a hindrance or as an instrument to better development outcomes. I then surveyed responses to this engagement and demonstrated how faith-based organisations have been 
examined and categorised. In this context, Missionary organisations are almost an 'invisible' NGO. Finally I briefly discussed Christian missionary organisations as faith-based organisations and argued that they are situated in a complex position between secular development and propagation of Christianity. In the following section I present some of the research on people who work in development contexts. The impact of faith on those who implement development is frequently absent in these analyses.

Duncan McDuie-Ra and John Rees argue that it is important to talk about religion not in order to graft it "onto existing ways of understanding and practicing development" rather because it is

a primary element in most of the locations where development interventions take place. Religion exists in the lives of those subject to the policies derived from development agendas and in the lives of those formulating such policies [my emphasis] (McDuie-Ra \& Rees, 2010, p. 22).

To understand more about the people who implement faith-based development in my research, I briefly look at how people who implement development (development workers) have been researched to date.

\section{Part two: The development of an aid worker}

The neglect of the personal dimension in development at first sight seems bizarre. It is self-evident to the point of embarrassment that most of what happens is the result of what sort of people we are, how we perceive realities, and what we do and do not do (Chambers, 1997, p. 1749)

\section{Introduction}

Little has been written about the people who implement development (Fechter, $2012 b)$. This absence is acknowledged and partially addressed in a recent journal issue of the Third World Quarterly (Volume 33, Issue 8, 2012), Special Issue: The Personal and the Professional in Aid Work.

In this section I briefly discuss research on development workers. I argue that much of the research into development workers has concerned discourses of the development expert and stems from postcolonial critiques of development. Further research has taken an ethnographic approach to understand more fully the aims and motivations of development workers. Finally I argue that these 
analyses do not extensively consider the religious or spiritual motivations of the people who 'do' development.

\section{Who are development workers?}

The often-repeated adage quoted by R. L. Stirrat is that development workers are mercenaries, missionaries, and misfits (Stirrat, 2008). ${ }^{22}$ However, given how many development workers there are, ${ }^{23}$ surprisingly little research on this group of people exists. Historically a vast number of books were written by colonial expatriates about life in the colonial empires. There are many biographies and autobiographies written by and about aid and development workers. ${ }^{24}$ In recent years the rise of blogging has meant that any development worker with access to a computer has been able to reflect publically on their experiences working in 'development' and in a 'developing country'. ${ }^{25}$ These writers and development workers are often reflective, highly critical and have read, studied and researched 'development' extensively. Anne-Meike Fechter argues that the popularity of blogs and memoirs demonstrates how significant 'the personal' is for aid workers, (2012b, p. 1388). She also contends that these blogs and memoirs demonstrate that

aid practitioners are not only well aware of what they do, but expend substantial efforts reflecting on what they are doing, why they are doing it, and what they should be doing (2012b, p. 1393).

However, personal reflection has not translated into extensive academic research in to how development worker identity influences, shapes, or is shaped by the 'development' work they do. We still know little about who development workers are, "where they are from, their hopes and dreams and their own views of what they are doing" (Stirrat, 2008, p. 406).

\footnotetext{
${ }^{22}$ A friend recently working for an NGO in Afghanistan added 'the broken-hearted' to this list.

23 Silke Roth writes that "representative data concerning those involved in aid is not easily available" (Roth, 2012, p. 1462). See also P. Walker, Hein, Russ, Bertleff, and Caspersz (2010, p. 11) who write "Due to poor data and vague definitions we really do not know how many aid workers there are in the world, how many of them work in the humanitarian field and how many of that subset could be termed professionals." P. Walker and Russ (2010, p. 2223) argue there are 210,000 people employed in humanitarian assistance.

${ }^{24}$ Stirrat refers to The World's Banker: A Story of Failed States, Financial Crises and the Wealth and Poverty of Nations, (Mallaby, 2004) and Emma's War: An Aid Worker, a Warlord, Radical Islam and the Politics of Oil - A True Story of Love and Death in the Sudan (Scroggins, 2002). See also Emergency Sex (and other desperate measures), (Cain, Postlewait, \& Thomson, 2005).

25 There are many blogs by development workers, see for example http://chrisblattman.com/, http://stuffexpataidworkerslike.com/, http://aidthoughts.org/ and a great many others. There are also many blogs set up by short term development volunteers, written mostly for the benefit of family, which if examined may illustrate the emotional and intellectual engagement of people 'doing' development. Anne-Mieke Fechter writes that "aid blogs lend themselves especially to voicing experiences and concerns which straddle the professional and the personal .... The attitudes and tones adopted vary widely, and range from the enchanted to the embittered" (2012b, p. 1395).
} 


\section{Agents of development: identity shapes aid}

Until recently who development workers are has been largely ignored in development research. However, as Morgan Brigg argues, development workers 'selves' are central to "development knowledge, practice, and in the wider social and political dynamics of development efforts" (2009, p. 1412), because "who we are may be one of the most important and pervasive motivating and organising forces in how we conceptualise and undertake development efforts" (Brigg, 2009, p. 1423; see also Chambers, 1997; Kaufmann, 1997). Development happens around and through relationships (Brigg, 2009; Eyben, 2012; Kaufmann, 1997), and "recognising the relevance of the personal provides a more comprehensive understanding of how aid works, and can therefore help to improve practice" (Fechter, 2012b, p. 1388).

\section{The development expert}

Development or aid workers are often examined in the light of what they do and their connection to larger discourses or theories of development. Much of this scrutiny is concerned with the rise of the 'technical expert'. It is argued that the process of westernised modernisation creates a perceived need for technical expertise. Consequently countries that are 'modernising' are seen to be in need of technical aid, which is supplied in machinery and personnel, namely the development expert. In this discourse the [western] expert is seen to hold knowledge and answers to perceived problems; through supplied expertise countries are assisted to develop (Parpart, 1995, p. 225). Here development experts

became, and continue to be, essential to the development enterprise, as development policies and programs are largely predicated on the assumption that development problems can be reduced to technical, i.e. 'solvable' problems which involve the transfer of Western technical expertise to the developing world (Parpart, 1995, p. 225).

Researchers have critiqued development for this expertise approach, arguing that it is steeped in paternalism and stems from an Enlightenment-based colonial paradigm (Crewe \& Harrison, 1998; Kothari, 2005, 2006b; McKinnon, 2007; Parpart, 1995; Stirrat, 2000). Such assessments of development workers examine their role within discourses of power and links particularly to the colonial continuities which can be found in the work, aims, and motivations of this group. Development workers are considered by these authors as consultants (Stirrat, 
2000), experts (Crewe \& Harrison, 1998; Escobar, 1995, 1997; Parpart, 1995), professionals (McKinnon, 2007), and technocrats (G. Wilson, 2006).

Jane Parpart argues that as professional expertise became an important marker in European development it consequently is seen as central to the development of the 'other' (Parpart, 1995, p. 223). The discourse of expertise is read as a form of cultural imperialism, used to reinforce notions of 'progress' and unequal power relationships between donor and recipient (Kothari, 2005). Development experts are seen as the essential foot soldiers of the development enterprise.

Critiques of development worker expertise also draw attention to the links between development work and colonial history as exemplified in the lives of those who 'do' development (Cook, 2007; Heron, 2007; Kothari, 2005, 2006b; Stirrat, 2000, 2008). The development professional, these authors argue, embodies the discourse of development which purports that "some people and places are more developed than others" (Kothari, 2005, p. 427) and therefore have the right and obligation to 'help' those less developed to achieve a similar level of development (Escobar, 1995, 1997; Heron, 2007; Parpart, 1995). It is through the development expert that these discourses are enacted and (re)produced.

\section{Ethnography of development workers}

Further research has more recently occurred through ethnographies of development workers such as those conducted by Nancy Cook $(2005,2006$, 2007, 2008), and Barbara Heron (2007) who both focus specifically on gender and colonial continuities in development worker identity. Cook was interested in

\footnotetext{
understanding how, through these processes of subjectivity formation Western women perpetuate, legitimate, resist and transform relations of domination as they imaging themselves in relation to the people among whom they live, construct communities and homes, and build careers and relationships in Gilgit [Northern Pakistan] (2007, p. 6).
}

Likewise Heron (2007) examines how women development workers construct a sense of 'moral self' through their encounters with a needy 'other' thus imbuing their development work with a moral obligation and a paternalistic attitude. Similarly Maria Eriksson Baaz (2005) analysed development worker identity through a postcolonial lens. She examined the discourse of development and the constructions of 'other' which occur in the narratives of the development workers 
she interviewed. These authors combine the critiques of the 'expert' and use postcolonial theories to provide a close reading of the aims and activities of development workers.

Attention has been paid to the motives of development workers, with particular consideration given to altruism and benevolence (see for example Heron, 2007; Kapoor, 2008). Fechter has noted that "a persistent focus on the 'other' amounts to a compartmentalising of 'aid givers' and 'aid recipients' into separate categories" (2012a, p. 1487), and that this "may explain the relative silence of development ethics on matters concerning aid workers" (2012a, pp. 1487-1489). Focus on an 'other' has fostered an inability to reflect on motivations and actions of the aid giver. She writes
placing aid recipients and aid givers in separate categories, together with an emphasis on collective rather than individual moral responsibilities, not only hinders necessary debates on the role of altruism and professionalism among aid workers, but also exemplifies how practices of 'othering' continue to inform aspects of development theory and practice (Fechter, 2012a, p. 1489).

Heron (2007) also analysed extensively how benevolence and the 'helping imperative' drive individuals to participate in development. Heron argues that through development work

Northerners continue to construct through the prism of a planetary consciousness a sense of self in moral terms that expresses the entitlement and obligation bourgeois subjects feel to 'help' Others (2007, p. 34).

Heron argued that development workers' helping imperative maintained structures of inequality and power imbalance between aid givers and aid receivers'. Heron further proposed that participation in development work for Canadian women is a means to achieve bourgeois subjectivity, in which case their 'altruism' is shaped by their own desires. This desire for development has been examined by Ilan Kapoor (2004, 2008). Likewise Marianne Gronemeyer (1992) writes that 'helping' in development is self-deceptive and hides power under a delusion of freedom.

In addition to this growing area of research into the development worker there is increasingly a focus on short-term development volunteers or 'voluntourists', much of which is critical and examines the aims and motivations of these 
development participants in the light of discourses of power, paternalism, and colonial continuities (for example, Simpson, 2004).

\section{Religion and development workers}

As noted at the start of this section, understanding who development workers are is important in understanding how development occurs in the way it does. Having previously examined the ways in which religion is approached in development it is significant to note that religion does not enter the aforementioned analysis of development workers except very briefly and peripherally. Heron (2007), for example, noted that for participants who were religious, belief both simplified and complicated the ways in which they enacted and formed their bourgeois subjectivities in relation to the Other. Cook argued in her study that in the close world of expatriate women in northern Pakistan, Christianity was a significant marker of identity and could be barrier in relationships with both non-religious development workers and with Pakistani locals (2007). In comparison Eriksson Baaz (2005) discussed the role of Christian missionaries very briefly but does not explore how, or whether, religion played a role in the lives of the people she spoke to and how this may or may not have affected their 'development worker' identity or role. ${ }^{26}$

While the 'religion' or faith/belief of development workers is not necessarily discussed, authors such as Fechter argue that

development as a field of practice is underpinned by personal beliefs and motivations, not least because it is driven, to some extent, by the idea of a collective moral responsibility of the affluent to address injustice and reduce poverty (2012b, p. 1396).

Personal conviction and morality (whether religiously shaped or not) is extremely significant in development practice. Development workers carry morals with them and attempt to shape the world according to their moral compass.

Although the current role of religion was infrequently discussed in research on development workers, the historic role of Christian missionaries was recognised. Stirrat discussed how NGO workers are colloquially considered to be the children

\footnotetext{
26 This absence may be a reflection on the ways in which religion is removed from 'western' research and society. Patrice Buzzanell and Lynn Harter (2006) write about disrupting secular hegemony in organisations and the academy (see also Shahjahan, 2005; Shahjahan \& Haverkos, 2011).
} 
of 'missionaries', whereas consultants are described as the children of colonial officers (Stirrat, 2000).

In the context of the influence of postcolonial discourse in development expert critiques it is worth noting the absence of religion in postcolonial research. R. S. Sugirtharajah writes that postcolonial discourse has "sadly paid little attention to the potency of religion and theology among Third World peoples" (2004, p. 36). He argues that although postcolonial theories have responded to concerns on the representation of religions they have not "come up with postcolonial theories or strategies to understand religions" (2004, p. 36, n.50) despite religion playing roles in "surviving, subverting and challenging colonialism" (2004, p. 36). Robert Young, too, notes that

an absolute division between the material and the spiritual operates within postcolonial studies, emphasizing the degree to which the field is distinguished by an unmediated secularism .... Postcolonial theory, despite its espousal of subaltern resistance, scarcely values subaltern resistance that does not operate according to its own secular terms (2001, p. 338).

Postdevelopment theory has to some extent considered spirituality (for example Rahnema, 1997), largely advocating a pre-European/pre-colonial spiritual ideal.

For my own research it is significant to note that the studies which used a postcolonial lens to examine development worker identity made an apparent assumption of secularism among development workers whereas other research has noted not only the significant motivational impact that religion often has for development workers (Bornstein, 2005; McGregor, 2008), but also the ways in which faith traditions influence secular development worker identities such as in the eschatological nature of development (Parfitt, 2009) or the assumption that development is about positive change (Fountain, 2012).

\section{Summary on development workers}

In this section I argued that little has been written academically on development workers. I further noted that research so far undertaken mostly examines development workers as actors within development discourses. There is an apparent assumption of secularism within much research on development workers. This may be partially influenced by a corresponding absence in postcolonial theory, and is further emphasised by the lack of spiritual theorising in the academic environment. Furthermore I emphasised that research which takes 
a closer reading of the aims and motivations of development workers has sidelined the position of religion or the role of faith in these narratives. I contend that religion or spirituality can be a significant motivator for development workers and that as development workers are part of discourses of power and implement these discourses through their development practice, it is important to include their religious understandings in discussions on development worker identity.

\section{Part three: Religious development workers}

Some researchers have chosen to refer to religious actors rather than faith-based organisations in recognition of the varied ways in which religion is incorporated into development. McDuie-Ra and Rees argue that religious actors tend to be viewed as homogenous group when in fact they are highly diverse and

are deeply involved in both top-down development and in contesting development: thus a singular form of agency cannot be generalised to all religious actors involved in development (McDuie-Ra \& Rees, 2010, p. 21).

There is some consideration of this diversity in the literature of religious NGOs. ${ }^{27}$ However the role of faith in the identity of religiously motivated actors in development spaces is still largely unknown. I argue that this applies to Christian missionaries and therefore chose to look at these religiously motivated actors.

As development actors missionaries are an almost entirely unknown group. As discussed earlier, Christian missionaries can be understood as people who believe they are commissioned (by God) to a task, often in a different country or environment. Missionaries may come from any Christian denomination or background. Missionaries participate in various activities ranging from social service provision to evangelisation (Deneulin \& Bano, 2009; Kim, 2010).

As with development workers a plethora of biographies and autobiographies of missionaries circulate, both historically and currently. ${ }^{28}$ There are also any number of missionary blogs, many of which are written exclusively to inform friends, family and supporting churches of the missionary's activities. Furthermore many missionary organisations have records, newsletters,

\footnotetext{
${ }^{27}$ Andrew McGregor (2008) briefly examines the spiritual motivations of Christian RNGO workers and also how spirituality may effect these people's perceptions of development. Erica Bornstein (2005) has written an extended ethnography of faith-based workers in one NGO in Zimbabwe. Wendy Tyndale has collated narratives of faith-based localised initiatives (Tyndale, 2006).

${ }^{28}$ For example Davis and Clark (2011); Elliot (1987); G. Smith (1990).
} 
monographs, books, and back-papers dating from their early meetings. These sources often detail the work and belief of missionaries historically and today, they are useful for understanding the faith of missionaries or learning of the activities they undertake. These sources also in some cases illustrate how missionaries were and are complicit in colonial and neo-colonial undertakings and the ways in which these are resisted. They can reveal motives and aims and enactments of these colonial continuities.

I wish to emphasise here the diversity of religious actors. While research on 'missionaries' and development is limited, I have found that there is fluidity in how mission and missionaries are defined and how they understand themselves. This can be seen in Erica Bornstein's (2005) research on Protestant NGOs. She recognises that 'mission' is an element of these NGOs (see also Hovland, 2008), similarly (and often unacknowledged in development research) mission organisations may be 'doing development' without ever calling it such. ${ }^{29}$ For most (but not all) participants in this study, living in Bangladesh resulted in 'development' work for a Christian NGO. Despite many people's reluctance to call themselves missionaries, all participants were registered with and working with a mission organisation.

\section{Conclusion}

In this chapter I examined the ways in which the development enterprise has responded to and incorporated religion and religious beliefs. I argued that religion was considered a hindrance or irrelevant to development. Where religion was incorporated it has been primarily through an instrumental approach. Within this context the specific position of Christian mission was briefly discussed. I also examined the literature concerning the people who 'do' development. I argued that this research demonstrates the colonial continuities found in development workers. Finally I related this analysis to the discussion on religion and development and argued that the research in development worker identity has not examined the role of religion in this identity.

The literature on the role of religion and development tends to look at organisations, programmes and practices of FBDOs and RNGOs without analysing the people who 'do' faith based development. The literature on the

\footnotetext{
${ }^{29}$ Philip Fountain's research with the Mennonite Central Committee (MCC) is an interesting
} exploration of these dual roles (Fountain, 2011, 2012). 
people who 'do' development tends to side-line or ignore the role of spiritual belief in these people's lives, though as acknowledged by Heron (2007) it can both 'complicate and simplify' the motives and practices of these people. This is therefore where I situate my research.

Sabina Alkire writes that "religion cannot be tidily isolated from other factors at work within and among people and groups" and that there is room for
deeply local historical, anthropological, economic, missiological or sociological studies in which religion takes its place alongside other variables, and in which a much more nuanced account of interactions is allowed to emerge (2006, p. 508).

In the following chapter I describe my research approach and consider some of the difficulties I experienced in research. 


\section{Chapter three: Research Approach}

\section{Introduction}

In this chapter I outline my research approach. I identify feminist and poststructuralist epistemologies which influenced my research. I then describe my methods throughout the research process, including who I spoke to, and how I analysed information.

\section{Epistemologies}

Feminist epistemologies have broken ground in reimagining research processes. Adopting feminist epistemologies allowed me to situate myself in the production of knowledge (Haraway, 1988), to think and write reflexively on the production of knowledge and ways of knowing (Cope, 2002; Fonow \& Cook, 1991; Letherby, 2003), and to acknowledge the personal and emotional in this knowledge production (Cope, 2002; Fonow \& Cook, 1991).

In practical ways feminist 'ways of knowing' has shaped my research approach. Pamela Moss writes that

feminist methodology is about the approach to research including the conventional aspects of research - the design, the data collection, the analysis, and the circulation of information - and the lesser acknowledged aspects of conventional research relationships among people involved in the research process, the actual conduct of the research, and process through which the research comes to be undertaken and completed (2002, p. 12).

My practical incorporation of feminist ways of knowing was to build relationships with participants and to research reflexively. I also recognised that reflexivity "can make us more aware of asymmetrical or exploitative relationships, but it cannot remove them" (England, 1994, p. 86). I have however struggled to place my research as 'action orientated' or political (Fonow \& Cook, 1991, p. 2). ${ }^{30}$

My research was also influenced by poststructuralist epistemologies. I wrote

And then ... I sit down alone and write about what I think and what I heard today. It is very odd. And not what I expected. But I like it.

\footnotetext{
${ }^{30}$ Some feminist researchers argue that feminist research should be explicitly political (see Mies, 1991; Moss, 2002), entailing 'liberation' (Fonow \& Cook, 1991, p. 6). I am uncertain whether my research '(re)politicizes' (Moss, 2002, p. 3). See also (Gibson-Graham, 1994)
} 
My queries come though when I think about 'is this knowledge?' though that is the wrong way to look at it (2011, reflective journal, 21 Nov.)

I include the above quote from my journal because it demonstrated my response to poststructuralist understandings of the production of knowledge.

Norman Denzin and Yvonna Lincoln write that "poststructural feminist theories emphasise problems with the social text, its logic, and its inability to ever to represent the world of lived experience fully" (2005b, p. 24). ${ }^{31}$ Poststructuralism is centrally concerned with language, linking it with "subjectivity, social organisation, and power" (Richardson \& St. Pierre, 2005, p. 961). The poststructuralist approach identifies language "as not merely reflective but instead as constitutive of social life" (Mansvelt \& Berg, 2010, p. 339), consequently in analysing this research, I have taken a close reading of the language used by participants. In poststructuralist approaches complexity and contradiction "needs to be embraced, not dismissed" (England, 1994, p. 81). Poststructural epistemology also allowed me to "reflect on ... method and to explore new ways of knowing" (Richardson \& St. Pierre, 2005, p. 962).

Using poststructural epistemologies I also recognised the importance of locating research in specific context and positionality (Mansvelt \& Berg, 2010, p. 339); consequently I attempted to locate myself within my analysis. However, I also acknowledge that it cannot lead to more objective research, as it is impossible to know "fully both self and context" (Rose, 1997, p. 311; see also England, 1994, p. 84; Mansvelt \& Berg, 2010). Instead I am hoping to

take responsibility for [my] perspective and position in research ... through reflexively acknowledging and making explicit those choices that have influenced the creation, conduct, interpretation, and writing-in of the research (Mansvelt \& Berg, 2010, p. 348; see also Haraway, 1988; Rose, 1997).

Following my epistemological choices I chose qualitative approaches. Qualitative research acknowledges that "subjective meanings are negotiated socially and historically $\ldots$ are formed through interaction with others ... and though historical and cultural norms that operate in individuals' lives" (Cresswell, 2003, p. 8). In conducting qualitative research I seek "to understand the world through

\footnotetext{
${ }^{31}$ They write "according to poststructuralism, language is an unstable system of referents, thus is it impossible to ever capture completely the meaning if an action, text, or intention" (Denzin \& Lincoln, 2005a, p. 27, n.6).
} 
interacting with, empathising with and interpreting the actions and perceptions of its actors" (Brockington \& Sullivan, 2003, p. 57). As Annette Lareau notes, "using qualitative methods means learning to live with uncertainty, ambiguity, and confusion" (1996, p. 198).

\section{How this research happened}

\section{Why missionaries in Bangladesh?}

I deliberately chose to interview and research people within an area of comparative social similarity (reciprocal relationships) because I was afraid of partaking in and producing unequal and extractive research (Dowling, 2010, p. 32). I acknowledge that this is also flawed, ${ }^{32}$ that there are always relationships of power when conducting research, and that "exploitation and possibly betrayal are endemic to fieldwork" (England, 1994, p. 85).

My decision to research in Bangladesh was based on my previous experiences living there and the relationships I still had with people living there. Consequently, when it came to finding people to talk to I was able to contact family and childhood friends, and from there 'snow-ball' further recommendations. The most significant aspect of my 'entry' to the field was my personal history. Other researchers have written of their anxiety over gaining 'entry' (see for example Lareau, 1996). I felt this was not the case in my research. My Christian missionary childhood resulted in specific points of access and ways of interacting, including an (almost) automatic 'in' and an ability to participate in significant social activities such as attending church. Interviews with people with whom I had no prior relationship included a discussion of my childhood in Bangladesh, and new participants were contacted through shared social activities, particularly around church.

My history identified me as a partial 'insider', which I compared to the experience of 'native' researchers (K. Narayan, 1993). While I am not 'native' to Bangladesh, I nonetheless felt comfortable travelling there; the food, language and dress were familiar to me. I was also familiar with the world of missionaries in Bangladesh, though again not 'native'. In this sense I was an 'insider' in the Bangladesh expatriate missionary world. However, while I can speak 'mission language' and I

\footnotetext{
32 Gayle Letherby writes that "speaking only for ourselves could also lead to much more research on already privileged groups and implies that women who come from minority groups have a 'duty' to represent 'others' like them". She writes that "furthermore, if we cannot speak for 'others' then 'others' cannot speak about 'us', which inevitably stifles criticism and critique" (2003, p. 135).
} 
know mission history, this does not mean I am truly an insider, as Elizabeth Chako (2004, p. 54) also noted in her work, "linguistic capability [did] not translate into cultural fluency." Some of this is illustrated in an email to my supervisors

Being here as a researcher is completely different to being here as a tourist or because I live here. It is confusing. I know the rules for being a tourist or a resident. And to a certain extent I am able to follow those rules (like dress codes, and where to walk, how to eat with my hands, and how to shop). But as a researcher, especially in my relationships, I am struggling. I feel like I have to say straight away, as soon as I meet someone that I am here to do research, so in a sense I feel particularly marked - like people might see me as a secret teller (2011, pers. comm., 13 Nov.).

As Kirin Narayan notes, there are elements of insiders and outsiders in all researchers and "even as insiders or partial insiders, in some contexts we are drawn closer, in others we are thrust apart" (K. Narayan, 1993, p. 676). ${ }^{33}$

My history, particularly my religious history, granted me a partial 'insider' status, however spirituality and belief were also the point where I felt most unclear about my insider/outsider status. This struggle may be influenced by the challenging role that spirituality plays in research. Despite the difficulty of being an insider/outsider, Chako promotes the 'in-between' position as a way to "resist dominant ways of acquiring information and regulating the production of knowledge" (2004, p. 54).

\section{To whom did I speak?}

This research risks privileging already privileged voices (Letherby, 2003). Missionaries have somewhat marginalised voices in the secular academic world, ${ }^{34}$ however many are still highly privileged in multiple ways. Choosing to focus on these narratives in order to highlight the difficulty of responding to faith/belief in development may further marginalise other voices in this debate. Bearing this in mind I nonetheless wanted to reflect (and prompt others to reflexivity) on the 'mission-development' nexus (Fountain, 2012) as it was presented in the everyday lived experiences of my research participants.

\footnotetext{
${ }^{33}$ Einagel (2001, p. 223) writes that the ambiguous and double positionings of insider/outsider is not unusual for ethnographic research.

${ }^{34}$ Brian Howell has argued for the inclusion of Christian identity as "a valuable ethnographic standpoint" (2007, p. 317).
} 
I conducted 11 semi-structured interviews with religiously motivated people working in Bangladesh. Of these, ten were 'bideshi', ${ }^{35}$ one was Bangladeshi. When speaking to people I realised that not everyone was comfortable with the term 'missionary'. Some self-consciously tried to distance themselves from the word. All however were religiously motivated to live and work in Bangladesh. ${ }^{36}$

\section{How did I research?}

My methods were based primarily on qualitative semi-structured interviews and participant observation. I also researched through 'friendship as method', collaborative reflection, 'hanging out', listening to stories, and participating in everyday activities. I prioritised building relationships and tried to be flexible and accommodating in setting interview times and places.

\section{Semi-structured interviews}

Interviews explored how participants described themselves and understood their activities. I was interested in understanding how these missionaries understood and 'did' development as well as how they understood and 'did' mission. I initially did not realise how fluid those terms would be for the people with whom I spoke. After arrival in Bangladesh I adjusted my original interview questions (see Appendix C) and asked open-ended questions about how participants came to Bangladesh, what they did, and why they did it.

All interviews were recorded and most were under one hour in length. ${ }^{37}$ Additional conversations and discussions were not recorded but were described in a field journal. ${ }^{38}$ All interviews were conducted in a place chosen by and convenient for participants. Four were in work places (one of these was on a project site). One was in a church. One was on a boat as we travelled to Dhaka. The rest were at the home of the interviewee. Most places were quiet, comfortable, with chairs, tables and hot drinks. The church was large and deserted. The boat was noisy and we were interrupted several times. Interviews in people's homes were interspersed with conversations with other family members.

\footnotetext{
${ }^{35}$ Bideshi is the Bangla word for foreigner. It means not of this country [desh = country/land]. It is widely used as a self-identifier by white expatriates in Bangladesh.

${ }^{36}$ From an explicitly Christian (largely evangelical) religious viewpoint.

37 The longest was close to four hours

${ }^{38}$ Field journals may be significant resources in participant observation especially. Recent research has argued that we should pay more attention to field diaries and what they demonstrate of the researcher (S. Punch, 2012)
} 
Participant observation and 'deep hanging out',39

I had thought that the bulk of my research would be held in interviews but it isn't. I interview only a little but I 'hang out' lots. I try to ask questions. I help cook, I try to listen and push in - I think that is what worries me partly, the self-consciously pushing in to people's lives and conversations (2011, reflective journal, 21 Nov.)

The main component of my field research was participant observation, requiring participation "in the daily activities, rituals, interactions, and events of a group of people as one of the means of learning the explicit and tacit aspects of their life routines and their culture" (DeWalt \& DeWalt, 2001, p. 1). For me this included attending formal events (team meetings, jama'at ${ }^{40}$ /church, prayer meetings, Bible studies, school events), and informal activities (helping in the house, looking after children, cooking and eating together, visiting people, watching movies, playing and listening to music, and walking together).

Using this method I aimed to "construct an in-depth interpretation of a particular time and place through direct experience" (Kearns, 2010, p. 242). I chose to live with participants. I hoped to observe and build connections with people from whom I wanted to learn. I was able to repeatedly ask questions based on what I saw and also return to issues in which I was interested. In this I followed the recommendation of one participant who cited James Spradley (1979, p. 4) "instead of collecting 'data' about people, the ethnographer seeks to learn from people, to be taught by them."

I enjoyed the social aspects of this kind of research. Participation in these "less structured settings ... helped me understand the contextual issues that impacted their [participants] lives" (Chako, 2004, p. 56). The interviews with the people with whom I lived now seem much more in depth and relevant (see also Humble, 2012). It was additionally important to me that I participated as well as observed. My participation in daily life and my participation in spiritual life were significant parts of changing the focus to participation not just observation (Fountain, 2011, p. 28).

\footnotetext{
${ }^{39}$ See Clifford (1997), and Fountain (2011)

40 Jama'at is a religious meeting in Bangladesh. I have used this word because it was used by some of my participants to refer to a Christian meeting (church). It was part of their contextualisation and assimilation with their Muslim neighbours. I heard it repeatedly and considered its use significant so I have chosen to use it here and throughout the thesis. Jama'at is "an Islamic council or assembly [from] Arabic jama'at group, congregation" (Collins English Dictionary, n.d.).
} 
Participation also gave me "access [to] embodied forms of knowing" (Nairn, 2002, p. 150). When asking participants about being white/bideshi/western I was able to reflect on how those subject positions were enacted by me when I covered my head outside, as my (female) hosts did. Like Karen Nairn, I thought it

important to include myself as subject of data rather than collect data solely about the 'object' of research because I was conscious of feminist critiques of disembodied researchers who are absent from their research (2002, p. 150).

As a result, I too have deliberately tried to write myself into this research.

An 'ethic of friendship'41 (Tillmann-Healy, 2003, p. 735) was also built into my participant observation; requiring methods that "build and sustain friendship: conversation, everyday involvement, compassion, giving, and vulnerability" (Tillmann-Healy, 2003, p. 734). Friendship as method "demands radical reciprocity, a move from studying 'them' to studying us" (Tillmann-Healy, 2003, p. 725). I value this highly. In my analysis I reflected on my relationships as I wrote. In doing so I hoped to move in the direction of studying us. Chako says that field research "brings to the fore issues of self and self-disclosure, power arrangements in society, and the subjective values of identity and power in the production of knowledge" (Chako, 2004, p. 58). In trying to focus on 'us', emphasising relationships, and writing myself in I wanted to acknowledge some of these issues of power and the production of knowledge.

I found I experienced ethical dilemmas as a participant observer, I felt extremely awkward presuming on my friendship to ask people in Bangladesh questions about my research (Scheyvens, Nowak, \& Scheyvens, 2003, p. 160; see also DeWalt \& DeWalt, 2001; de Laine, 2000, p.77; Tillmann-Healy, 2003). I struggled with the lines between conversation and research, and wondered what I could include in my final discussion. My research methods accentuated my confusion. I wrote

I have ... been wondering where research ends and where life begins ... When I go to a Bible study run by people in the house, is that research? Can I write about that? Do I need consent from everyone there? (2011, reflective journal, 13 Nov.)

\footnotetext{
${ }^{41}$ Friendship as method has influenced this 'ethic of friendship' aspect of my methods
} 
I found that my friendships sometimes led me to question the ethics of my choice of method. ${ }^{42}$ Kim England has noted that the greater the overlap between researcher and researched in social and cultural background, the greater the ease in communication (1994). My own experience was that although common experience facilitated conversation, it also made me more uncomfortable with the research process and the ethics of research (see also Mullings, 1999). In fact I longed for distance in the hope that it would somehow provide more clarity on the research and ease the process. My own experience was much more like Nairn, who writes "although participant observation offered the most potential for embodied forms of knowing ... it also felt the most intrusive" (2002, p. 150). I discussed this with one participant who said "[if] you get something wrong. It's ok. It's not the end of the world" (2011, Joy interview, 29 Nov.).

Questioning what was 'ethical research', I struggled to come to terms with thegap between the "gruelling test to write an ethics proposal" (Scheyvens et al., 2003, p. 139) influenced by "traditional, postpositivist orientations" (Cannella \& Lincoln, 2011 , p. 81) and the lived experience of researching my hosts and friends. I wrote

\begin{abstract}
"What I suppose is obvious but it has taken me a while to realise is that ethics is not the piece of paper to sign ... for me to feel ethical about pushing in on other people's lives I need to talk to my friends and hosts and ask them what I can incorporate of what they have told me .... The recorded interviews are much easier to define as research, and so the ethics consent is much easier. It is the informal conversation where I feel uncomfortable and where I need to be consciously discussing ethics with my hosts and friends" (2011, pers. comm., 27 Nov.)
\end{abstract}

While I abided by the ethics code of my university, I was also guided by an effort to be critically reflexive in my research process, involving "a commitment to theoretically informed, self-critical ethical conduct" (Dowling, 2010, p. 30). Flexibility and responsiveness were also important in doing ethical participant observation (DeWalt \& DeWalt, 2001).

\title{
Listening to stories
}

This is not narrative research. However an important part of this research involved listening to stories, some in 'official' interviews, and most in 'noninterview' space. These were stories about relationships, neighbours, failed

\footnotetext{
42 Maurice Punch asks "how 'honest' do you actually have to be about your research?" (M. Punch, 1998 , p. 168). Punch argues that research, particularly participant observation, always involves mutual deceit (M. Punch, 1998, p. 178), and is inevitably unethical. Judith Stacey argues that ethical issues are endemic to ethnography $(1988$, p. 121).
} 
projects, frustrations and joys of living in Bangladesh, relationships with neighbours, development workers, missionaries, expatriates, home communities, tourists, visitors, and researchers. Listening to stories required mutual relationships of trust.

The stories people told me during my fieldwork illustrated some of the ways in which people situated themselves in Bangladesh, particularly in relation to already existing narratives of 'development' and 'developing countries' ( $M$. Andrews, Day Sclater, Squire, \& Tamboukou, 2004, p. 112). Edward Carr argues that stories are a way in which we can understand "the power relations that exist between those from the Global North and the communities in which they work" (2010, p. 223). ${ }^{43}$ I valued the stories people told. I thought, as Andrews et al. say, that

we are storied selves ... that there is a close relationship between the stories we tell and hear and who we are; and that our stories are the cornerstone of our identities (M. Andrews et al., 2004, p. 112; see also Heron, 2007, p. 11).

\section{Engaging emotionally}

Emotions and relationships mattered in the research process. During field research I felt confused, anxious, intrusive and manipulative. I wrote

I feel a lot like I am exploiting relationships for research purposes. This is kind of odd, I never felt like that when I asked friends and family in Wellington what their opinions were. I went to church on Friday $^{44}$ mostly to meet people who I could interview. That feels very manipulative and dishonest (2011, reflective journal, 13 Nov.).

In this I recalled what Nairn had written about her experience, "I felt like I was exploiting social situations for work purposes" (2002, p. 150). ${ }^{45}$ These feelings also made me reflect on the nature of research. I considered how the history of research was largely extractive and exploitative and I wished to push against this. I wrote

\footnotetext{
${ }^{43}$ The terms Global North and Global South, like other such terms, are contested. I chose to them throughout this thesis for ease of reference and because authors whom I cited also used these terms.

${ }^{44}$ In Bangladesh most Christian church services are held on a Friday, this is because, in line with Islamic tradition, Friday is a public holiday.

${ }^{45}$ I felt recognition and some relief reading England's comment "I have to admit there have been interviews when I have listened sympathetically to women telling me about the details of their lives (my role as participant) while also thinking how their words will make a great quote for my paper (my role as observer)" (1994, p. 86).
} 
I have been reflecting more on why I feel uncomfortable talking here as a researcher whereas I didn't when I was in NZ. I think the act of relocating myself is intrusive. I came, uninvited to this place with these people, and that is under any circumstances intrusive (2011, reflective journal, 7 Nov.).

To then take information and rewrite it in my own words seemed extractive and unequal. Again it made me reflect on the process of researching. Feeling manipulative prompted anxiety on unevenness of gain; I gained "far more from [my] fieldwork than those who participate[d] in it" (Scheyvens et al., 2003, p. 155). Mandel argues for "the necessity of thinking reflexively not only about my role in the production of knowledge, but also about how I am feeling throughout the project" (2003, p. 208). My feelings throughout the field experience made me question the legitimacy of my role in the production of knowledge.

These issues of feeling anxious about ethics and the extractive nature of research (as well as questions over what is research) were emphasised by the research process including; the methodology I chose (participant observation, unstructured qualitative interviews); the limits of research at a master's level (particularly the short amount of time I had in the 'field'); and traditions of research within a secular academic institution (particularly my assumptions of academic protocol requiring a level of detachment impossible in my circumstance, and the expectation of individual work in the analysis and writing stages).

How I felt has continued to influence my research. As I struggled with representation of participants and analysis of material it is how I felt that has been dominant. In many ways acknowledging my complicity in the concepts I critique has been a way of alleviating my feelings of betrayal, meanness, and not understanding. Though I recognised too that alleviating my feelings by confessing complicity is also problematic, holding an idealised academic objectivity impossible to achieve and inherently flawed (Haggis \& Schech, 2000; Kindon, 2012; Rose, 1997).

\section{Analysis and 'writing in'}

I transcribed all interviews verbatim. I tried to retain pauses and hesitations to indicate emotions and conversational flow. To analyse material I read and reread transcriptions of interviews and my journal notes. I tried to categorise material into different themes, I drew spider diagrams and filled in charts trying to make 
sense of what I had seen and been told. I was influenced by Heron's (2007) analysis of development workers and, like Cook (2007, p. 19), I "attended to the surface regularities in narrative styles and devises, figures of speech, tropes and motifs, and categories of talk or action."

My initial intention was to find out what people were doing. I wanted to locate missionary activity in a spectrum of 'development' activity. However my questions over what people did led to analysis of the language they used. The ways people described what they did, as well as their activities became the centre of this research. I wanted to write about what missionaries were doing and how this was also development, but I could not avoid also reflecting on the colonial relationships between missionaries, development, and Bangladesh.

\section{How I write about people}

All participants have been given a pseudonym ${ }^{46}$, and details of where and for whom they worked changed. Throughout this research I have referred to participants or to 'people with whom I spoke' or 'people who spoke to me'. ${ }^{47}$ I have chosen to use the word 'participant' partially because it reflects the way this research was conducted (through personal relationships), and partially because I was a 'participant observer'. I am however aware of the complexities connected to use of this word (Letherby, 2003), and am aware that "every label the researcher or informant adopts, or is given, produces specific discourses" (Chako, 2004, p. 57). I was and remain concerned with issues of representation. This is not participatory research. I am responsible for choosing this topic, analysing the material gathered, and writing conclusions. I cannot claim to 'speak for' the women and men who I interviewed, and I cannot represent them without reference to myself. To paraphrase Chako, the analysis of the data gathered is entirely mine, even as I claim to represent the voices of others (2004, p. 58).

I have been influenced by participatory research methods, and am aware of, and wish to counter, the history of extractive research which serves to reinforce a

\footnotetext{
${ }^{46}$ Some people chose their own 'research name' while others were ambivalent, where possible I have used the chosen name.

${ }^{47}$ In Barbara Heron's analysis of development workers she writes "I use the first person plural so as to include myself within the nexus of these subject positions" (2007, p. 19) because "my concern is to place myself within the analysis and to signal that I see myself implicated in the issues I raise in respect to relations of domination" (Heron, 2007, p. 18). I have decided that in my analysis I cannot do the same, I am not a missionary and never have been. However, I want to acknowledge that I am deeply implicated in the processes described; the critiques I apply are also applicable for me. I am implicated in this analysis as it concerns both faith and relationships of power, both because of my personal history and because of wider relationships of inequality.
} 
dominant narrative particularly in cross-cultural research (see for example Chako, 2004 , p. 52). Furthermore the notion of the researcher as powerful prompted me to think about how I enacted relationships; "because of the power imbalance between researcher and participants, field relationships always have potential for colonization and exploitation" (Tillmann-Healy, 2003, p. 744).

\section{Reflecting on my subject positions}

Much has been written on the importance of "recognising the politics of position in research processes" (Mansvelt \& Berg, 2010, p. 338; see also Chako, 2002; England, 1994; Haraway, 1988; Marshall, 2002, p. 176; McDowell, 1992, p. 409; Valentine, 1997). Positionality influenced my methods and outcomes and was also in "constant negotiation" (Crouch, 2001, p. 72) as I interacted with the people around me. Three specific aspects of my positionality were particularly significant in this research. These were race, gender, and spirituality. In chapter six I reflect on the research process and consider my spiritual positioning particularly. I privileged spirituality over race and gender because of the way this subject position informed my reflections on participants' stories, however I incorporate analysis on the intersections between spirituality, race, and gender where appropriate.

\section{Conclusion}

In this chapter I described my epistemological and methodological approaches to research. I detailed my research activities, who I interviewed, how I identified participants, and some of the difficulties I encountered.

In the following chapter I briefly examine Christian missionary paradigms, history and engagement with 'development' in Bangladesh. 


\section{Chapter Four: Christian mission and Bangladesh}

\section{Introduction}

This chapter examines the context of Christian mission. Firstly I outline common definitions and understandings of mission. I overview the colonial missionary history looking particularly at the influence of the European Enlightenment and colonialism. Secondly the chapter presents a brief overview of the NGO sector in Bangladesh in the context of its colonial history and more recent 'development' patterns, particularly in relation to Christian missionary engagement. Both contexts set the scene for engaging with participants' stories in subsequent chapters.

\section{The context of Christian mission}

\section{Definitions of Mission}

Mission has been and continues to be considered a central aspect of the Christian practice of faith; the church "comes into being as a result of mission" (Kim, 2007, pp. 41-42; see also Deneulin \& Bano, 2009; Wright, 2006). Historically the church is "conceived in the context of the mission of Jesus Christ" (Kim, 2007; Wright, 2006, pp. 41-42). Christian mission is based in biblical interpretations and understandings and is influenced by historical, social, political, economic changes. Christians continue to debate understandings of how mission should be practiced as well as the centrality and relevance of mission.

Mission crosses religious boundaries to carry "message and promises" (Pachuau, 2000, p.550). Christian mission has been described as "crying and struggling with others to live today with dignity" (Conradie, 2005, p. 560); as transformation; and as multi-dimensional (Pachuau, 2000, p. 546). Mission may include

verbal proclamation of the gospel, religious conversion, interreligious dialogue for mutual understanding and peace, promoting social justice, uplifting the down-trodden, and many others [activities] (Pachuau, 2000, p. 546).

Chris Wright has argued that the church was "made for ... God's mission" which can be understood as social, economic, and theological (2006, p. 62). 
The word 'mission' is from the Latin verb, missio, meaning to send, and was a doctrinal term used "to denote the sending of the Son by the Father, and of the Holy Spirit by the Father and the Son" (Bosch, 1991, p. 228). During European colonial expansion in the fifteenth century the term 'mission' was adopted to describe the political and ecclesiastical 'sending' of the colonising nations (Bosch, 1991, p. 228). As Mrinalini Sebastian argues, "the word 'mission' has cultural implications; it has a history and this history is entwined in colonial history" (2004, p. 76). Current mission paradigms remain influenced by this understanding of mission as sending and consequently retain strong links with colonisation.

\section{Mission Paradigms}

There have been many attempts to classify different concepts of mission (Bevans \& Schroeder, 2004; Bosch, 1991; O'Halloran, 2012; Ponsi, 1978). Mission can be simplistically understood under two key ideas about salvation, that it pertains only to specific spiritual beliefs or that salvation encompasses spiritual and physical change. Or

for some, the church has to give bread to the hungry so that they can hear and respond to the gospel proclaimed by the church. For others, the very content of the gospel includes giving bread to the hungry (Conradie, 2005, p. 560; see also Deneulin \& Bano, 2009).

Under the first category, mission focuses on salvation through belief in Christ, "salvation is not found in the transformation of the world or the enhancement of the human, but in the recognition of the world's transitoriness and the value of eternal life" (Bevans \& Schroeder, 2004, p. 49). This approach tends to have an evangelising and conversionary focus. Frank Ponsi (1978, p. 142) writes that mission as evangelisation "does not exclude involvement with economic development, social justice, education and the progress of people" however these are considered a preparatory aspect of mission, or as "the natural fruit of the salvation brought by the Gospel" (1978, p. 142).

The second broad type of mission encompasses spiritual and physical change. This mission paradigm has been described as a commitment to liberation and transformation (Byar Bowh Si, 2008; Thomas, 1981). This approach involves the church as a community working with God to make social change (Bevans \& Schroeder, 2004, p. 49). Mission as liberation often has a specific focus on economic change (Ponsi, 1978). These two broad strands of mission encompass 
much of today's missionary practices, ranging from liberation theology, holistic mission, and street evangelism.

These mission paradigms have shaped the relationship between mission and development. Thus for some development work is

an expression of how these traditions [Islam and Christianity] attempt to live their fundamentals in response to the social, economic and political context in with Islam or Christianity is practised (Deneulin \& Bano, 2009, p. 74).

For others, development work is a way to share beliefs more widely. Some Protestant paradigms of mission are currently influenced by 'holistic mission', an approach which hopes to combine spiritual and material change (see Hoek \& Thacker, 2008).

\section{History of the church in mission}

The historical foundations for mission in the church are found in the gospels of Mathew and Luke and the book of Acts (Bosch, 1991; Deneulin \& Bano, 2009; Kim, 2007). In these New Testament books mission is presented as a central activity of the church. Mission in this early church context has been interpreted as incorporating not just conversion to a belief but a commitment to social change

mission involves, from the beginning and as a matter of course, making new believers sensitive to the needs of others, opening their eyes and hearts to recognise injustice, suffering, oppression, and the plight of those who have fallen by the wayside (Bosch, 1991, p. 81).

Kirsteen Kim places the origin of Christian involvement in 'development' ${ }^{48}$ in the biblical example of the life of Jesus and the actions of the early church, saying that they shared everything they had, lived in community, and helped the poor and marginalised (Kim, 2007, pp. 5-6; see also Deneulin \& Bano, 2009; White \& Tiongco, 1997). From these early beginnings the church has applied 'development' and 'mission' in a wide variety of ways, depending on interpretation of the Bible, interactions with local culture, and in response to political, economic, and social context.

\footnotetext{
${ }^{48}$ I recognise that 'development' articulated today is a post-World War II conception which is not applicable in this early period of the Christian church. Nonetheless I have referred to development in part to provide continuity and in recognition of the colonial continuities found in 'development' and in part to refer broadly to social, cultural, and political intervention, mostly with the explicit purpose of bringing about 'good change' (Chambers, 2005).
} 
Creating social and spiritual change were seen as not only essential to belief but also as inseparable in Christian mission. However, this early church culture of the church changed as Christianity became the dominant religion in the Roman Empire (Bosch, 1991). When Christianity moved from being the religion of a marginalised group to a powerful majority, "non-Christian faiths were [considered] inferior to Christianity, not ... on theological grounds but for socio-cultural reasons" (Bosch, 1991, p. 193). As identified above, during the fifteenth century as European colonial empires expanded, mission came to mean "the activities by which the Western ecclesiastical system was extended to the world" (Bosch, 1991, p. 228). Thus mission and colonialism "as a matter of course, were interdependent; the right to have colonies carried with it the duty to Christianize the colonized" (Bosch, 1991, p. 227). However, in this new context the missionary activity of the church was not limited to the colonial activities of the state. Bosch argues that during this time monasteries continued the primary mission function of the church; working for and living with marginalised groups (Bosch, 1991, p. 232).

During the protestant reformation in the late fifteenth century Christianity was reassessed and new theologies emerged, including justification by faith alone, the centrality of personal faith and redemption, the belief in the priesthood of all believers and the supremacy of the Bible as the basis of doctrine (rather than the Pope or church hierarchy) (Bosch, 1991). These changes had profound implications for the protestant approach to mission. It produced both urgency, particularly among some church groups, and led some to acquiescence in the social, religious and political status quo (Bosch, 1991). The protestant reformation was followed closely by the Enlightenment leading to further changes in missionary paradigms.

\section{The Enlightenment, Colonialism, and Mission}

In many ways the Enlightenment has been a defining force in Christian missionary enterprise over the past 500 years (Bebbington, 1989; Bonk, 2006; Bosch, 1991). Similarly it has decisively shaped approaches to and constructions of 'development' (Heron, 2007). Through the Enlightenment dichotomies such as self and other, civilised and savage, and sacred and secular were established. These divisions shaped current conceptions of 'mission' and informed approaches to 'development'. Far from following separate trajectories mission and development reflected and constructed each other. 
Significant aspects of the Enlightenment which influenced the theory and practice of both mission and development are the concepts of progress and modernisation; the idea of 'value free' objective knowledge; the predominance of European ways of doing and knowing; and the centrality of the individual (Bosch, 1991). Under the influence of the Enlightenment, Christian belief increasingly became an individual activity, with particular attention to spiritual, rather than social, expressions of faith. This division is a reflection of the secular-spiritual divide found in Enlightenment thought and politics, and is still a major part of current understanding of the role of spirituality in public life (Hovland, 2008). Furthermore colonialism, the cultural and political accompaniment to the Enlightenment, played a substantial role in the practical as well as the ideological motivations for missionary activities, particularly in the nineteenth and twentieth centuries (Bosch, 1991). In David Bosch's assessment

the entire Western missionary movement of the past three centuries emerged from the matrix of the Enlightenment. On the one hand, it spawned an attitude of tolerance to all people and a relativistic attitude toward belief of any kind; on the other, it gave birth to Western superiority feelings and prejudice (Bosch, 1991, p. 344).

All of these aspects of the Enlightenment outlined above were incorporated into Christian belief (Bosch, 1991, p. 274). Andrew Porter, whilst arguing for recognition of variations between and within mission organisations, recognises that

in their attachment to ideals of rationality, progress, and the uniformity of both human nature and laws of social or economic development, Christian missions were in many respects representative of the eighteenth century Enlightenment as well as the offspring of the evangelical revival (1997, p. 376).

Missionary shifts were linked to the understanding of the march of 'western' progress. This progress was considered inevitable and incontestably positive. Missionaries "like all other westerners ... were to be conscious propagandists of this culture" (Bosch, 1991, p. 292). Unsurprisingly a "benevolent paternalism" emerged towards churches in the Global South "under which the younger churches just could not reach maturity, at least not according to Western church standards" (Bosch, 1991, p. 292; see also Bonk, 2006). This paternalism is criticised for producing a 'Peter Pan' syndrome in the African Church whose independence has been restricted because Christian mission continues to be 
"closely connected with the domination and exploitation of the colonial period ... the missions operated within a colonial ideology of development which they did not challenge theologically" (Kalu, 1975, p. 18). Enlightenment thought continues "to exert a profound influence upon both the ends and the means of contemporary Western missionary efforts" (Bonk, 2006, p. 33).

None of these aspects of Enlightenment thinking is exclusive to mission. On the contrary these were integral parts of Europe's approach to, and understanding of, the rest of the world throughout the colonial period and have continued into the 'development' era post World War II. Jonathan Bonk writes that

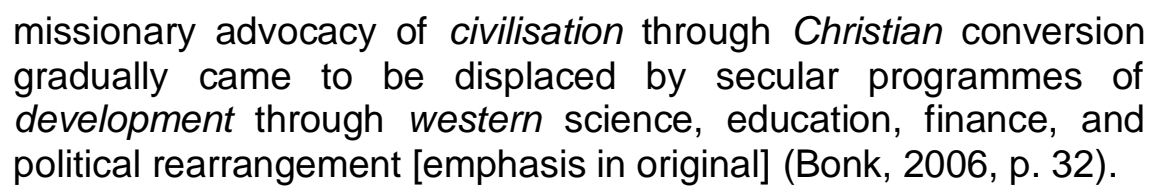

In addition, just as critics of the neo-colonialist nature of development have emerged so too have there been critics of the neo-colonialist nature of Christian mission, notably liberation theologians, and theologians from the Global South (see for example, Sebastian, 2004).

\section{Mission and Bangladesh}

Prior to British colonial rule Bangladesh was first part of the extensive Buddhist and Hindu empires that stretched over many regions of South Asia. During the Moghul (Muslim empire) period ${ }^{49}$ much of East Bengal (now Bangladesh) converted to Islam. Islam remains the dominant religion in Bangladesh, approximately 88 per cent of Bangladeshis identify as Muslim (Baxter \& Rahman, 2003). ${ }^{50}$ Throughout the seventeenth and eighteenth centuries British control over Bengal (and the rest of India) strengthened, culminating in the official annexation of the Indian subcontinent to the British Empire in 1858. As colonial control increased over the Indian Subcontinent Christian missionary attention was also drawn to the region.

\footnotetext{
49 The Mughal empire was centred in Delhi and the surrounding areas, it lasted roughly between the mid sixteenth and eighteenth centuries. At its strongest the empire stretched between Afghan territories in the west and Bangladesh's capital Dhaka in the east, the Indian state of Kashmir in the north and the southern Indian state of Tamil Nadu in the south, see Figure 2 for an overview of South Asia.

50 The remainder identify as Hindu (11 per cent), Christian, Buddhist or animist (Baxter \& Rahman, 2003).
} 


\section{Figure 1: Map of South Asia}

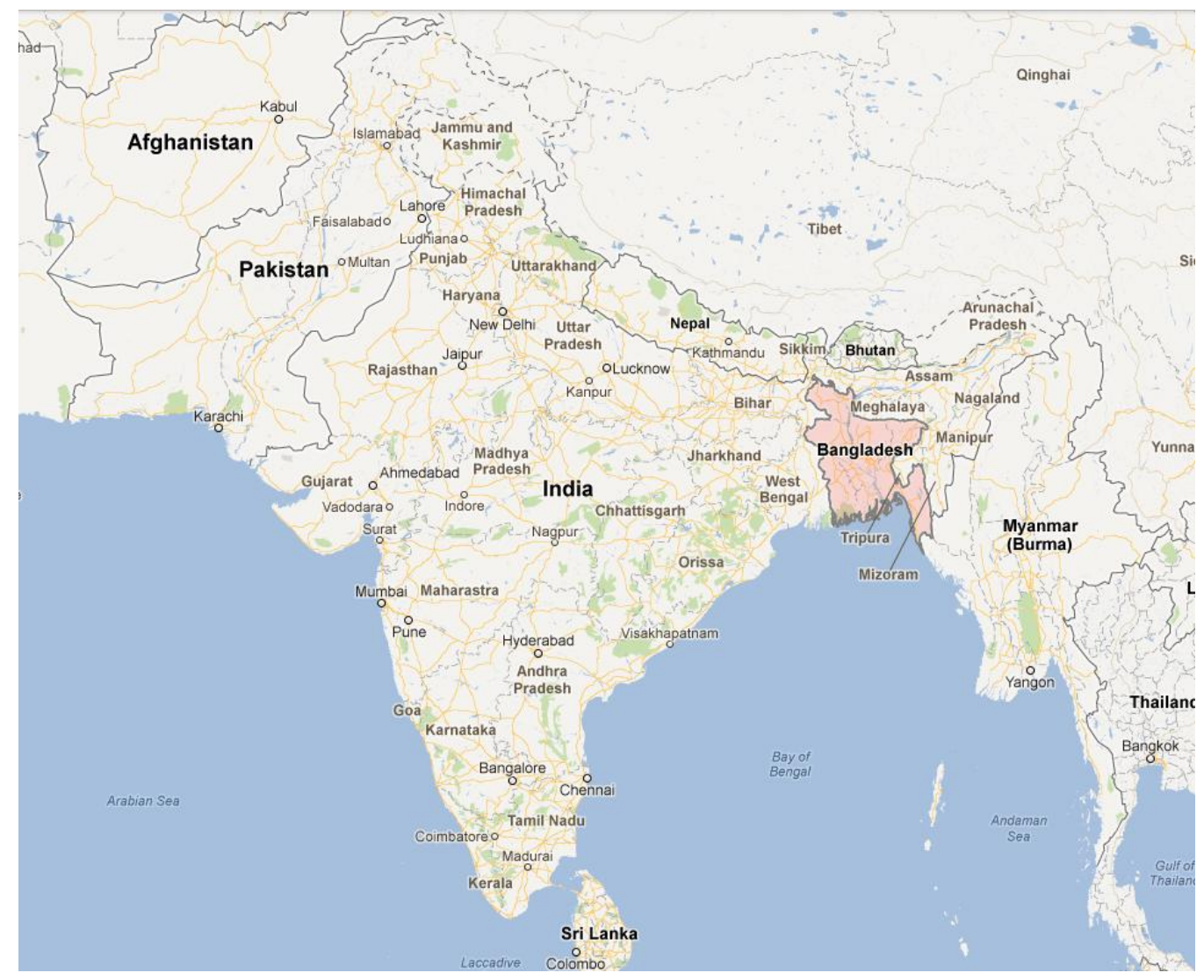

(Google Maps, 2012)

The first missionaries to Bangladesh were Catholics who followed Portuguese traders from the fifteenth century (Debnath, 2011, p. 465). However the first official mission opened in 1800 (Hedayetul Huq, 1999, p. 210). Following the rise of the British economic power in the region protestant missionaries established themselves in Bengal. ${ }^{51}$ Christian mission to the Indian subcontinent increased over the nineteenth century; it is evident that in many cases "Christianisation became a part of the colonising project" (Debnath, 2011, p. 466).$^{52}$ During this time Christian missionaries were active in education and health sectors (Lewis, 1997, p. 34; see also Debnath, 2011; Sugirtharajah, 2004). Additional 'development' activities or voluntary organisations were run by wealthy

\footnotetext{
${ }^{51}$ The Baptist Missionary society was one of the earliest Protestant missionary organisations to work in Bengal and have been active in the region ever since William Carey established the Serampore mission in 1800. On the Baptist missionary activity in the Bengal region see Stanley (1992).

${ }^{52}$ Extensive research exists as to the ways in which Christian mission and colonisation were mutually complicit, see especially Jean and John Comaroff (Comaroff \& Comaroff, 1997), for commentary on Bengal see Cosimo Zene (2002).
} 
individuals or mosques. ${ }^{53}$ Christian Missions are still strongly associated with colonialism and there is "lingering suspicion that the works of charity, service and welfare which missionaries performed were mainly a means of insinuating their way into the heart of the community they worked with" (Hedayetul Huq, 1999, p. 218).

In 1947 the Indian subcontinent achieved independence, out of which India and Pakistan were formed, Pakistan as a Muslim country including the former East Bengal, now Bangladesh (see Figure 1 for a map of Bangladesh). In 1971, after an extremely violent war in which the estimated death toll in Bangladesh was 3 million (Baxter \& Rahman, 2003, p. 19), Bangladesh gained independence from Pakistan on 16 December. During the independence struggle some missionary activity in Bangladesh continued, although restricted by the fragile political environment (Edgar \& Nees, 1985).

\section{Figure 2: Map of Bangladesh}

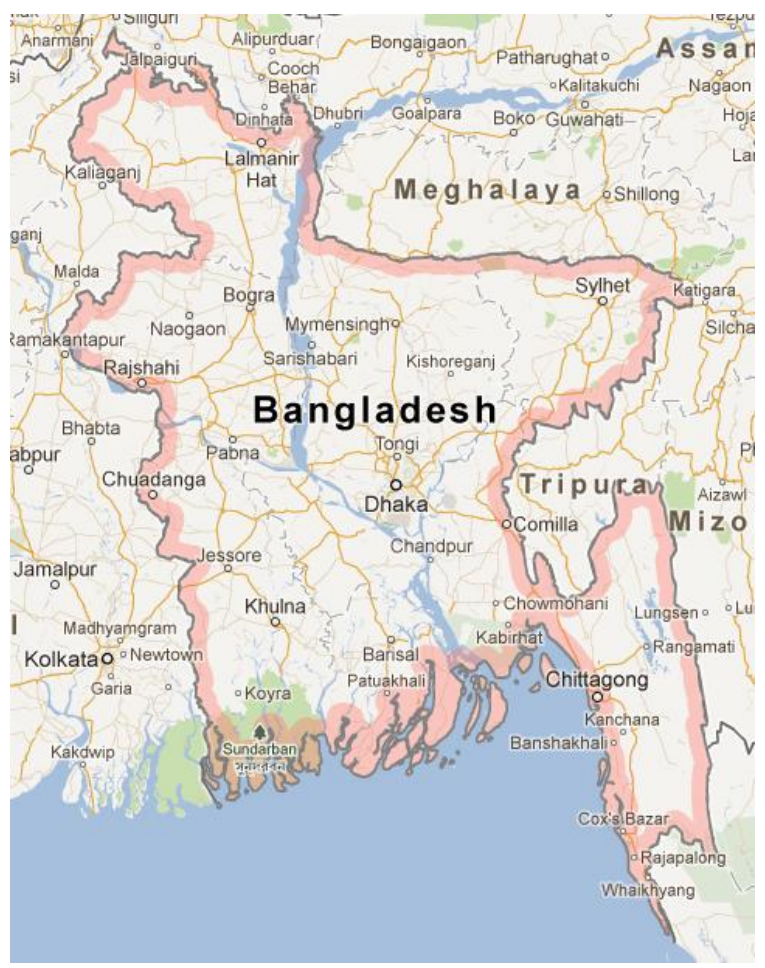

(Google Maps, 2012)

Since independence Bangladesh has experienced extensive periods of military rule (Ahmed, 2004; Milam, 2007), the latest of which was in 2008. Politics is

\footnotetext{
${ }^{53}$ The giving of alms is one of the five pillars of Islam and as such is a significant component of charities. For commentary on NGOs, Islam, and charitable giving in Bangladesh see Mesbahuddin (2010).
} 
dominated by the bipartisan leadership tussle between the Bangladesh National Party (BNP) and the Awami League.

Political, historical, and environmental factors have resulted in high levels of development NGO engagement in Bangladesh on all levels from bi-and multilateral donors, to the formation of large numbers of local NGOs as noted below.

\section{The non-government sector in Bangladesh}

Most of the current NGO activity in Bangladesh stems from the influx of international aid organisations which entered the country in the wake of the war of independence, working with refugees and those affected by the war (Karns, Shaffer, \& Ghere, 2008, p. 188; Lewis, 1997; Stiles, 2002; Zohir, 2004). S. Mahmud Ali writes that by August 1972 the international community had committed US\$900 million for post war relief and reconstruction (Mahmud Ali, 2010, p. 95). Key Bangladeshi NGOs such as Bangladesh Rehabilitation Assistance Committee (BRAC) also emerged during this period. ${ }^{54}$ The NGO position was reinforced in the immediate years following independence when a devastating famine in 1974 caused the deaths from starvation of between 30,000-100,000 adults (Mahmud Ali, 2010, p. 109)..$^{55}$

Post-independence the on-going political and social conditions in Bangladesh led to a substantial amount of aid and development intervention. Despite significant gains made on key social indices such as life expectancy, Bangladesh is still ranked poorly in global poverty and development indices. ${ }^{56}$

Development intervention in Bangladesh has taken a variety of forms and has occurred mainly along the lines of global development practices (Women in Development, Gender and Development, neoliberal restructuring, Participatory

\footnotetext{
${ }^{54}$ See http://www.brac.net/ for more information on BRAC.

${ }^{55}$ The number of deaths from the famine is disputed and difficult to know accurately, hence the broadness of the estimates. Mahmud Ali emphasises that the number he provided is of adults, "if the number of children and the elderly who succumbed to the same causes in this period were added, the toll would be much higher" (2010, p. 109).

${ }^{56}$ For example, according to the MDG Monitor 41.32 per cent of the population live below PPP\$1 per day (Millennium Development Goals Monitor, 2008). Purchasing power parity (PPP) is used as a comparative measure of development. It is used in the Human Development Index (HDI) to rank global living standards. Bangladesh has an HDI value of 0.5 . Countries with the highest HDI values include New Zealand at 0.908 (International Human Development Indicators, n.d.). While recognising the limitations of many of these statistics, I have nonetheless included them to provide an overview of how Bangladesh is perceived in many circumstances, particularly in the ways in which NGOs and Aid organisations approach Bangladesh and make policies and projects to cater to these statistics.
} 
development, among others). The influence and activities of the NGO sector in Bangladesh since independence has been considerable. NGOs are attributed with bringing about the significant reductions in poverty rate (Karns et al., 2008, p. 180) ${ }^{57}$ Bangladesh's own notable contribution to development interventions has been the introduction of microfinance initiatives for poverty alleviation (see for example Yunus \& Jolis, 2003). By the 1990s NGOs were active in more than half the villages in Bangladesh (Karim, 1996, p. 132), and their activities had expanded into "areas where typically government would respond, such as education and economic development" (Karns et al., 2008, p. 188). Current estimates of NGO numbers in Bangladesh range from between 17,000 to 23,000 . $^{58}$

According to Gauri and Galef the development NGO sector in Bangladesh is "highly organized and homogeneous", and is focussed largely on service provision, mostly around microfinance (2005, p. 2046; see also World Bank, 2006). ${ }^{59}$ Development directed NGOs in Bangladesh reportedly have five similar key features; they focus largely on poverty alleviation and/or advocacy; have a formal organisational structure; receive foreign funding; employ mainly Bangladeshi staff/management; and are mostly secular (World Bank, 2006, p. 13). ${ }^{60}$

The extensive reach of NGOs in Bangladesh led to government attempts to regulate the NGO sector more thoroughly. The 2006 World Bank report Economics and Governance of Nongovernmental Organizations in Bangladesh recognised that "gaps and weaknesses in the regulation of NGOs need to be addressed as a priority" (2006, p. 5). To this end the NGO Affairs Bureau (NGOAB) was formed in 1990 to monitor and control activities of NGOs in Bangladesh. All NGOs who receive international funding must be registered with the NGOAB. They may additionally be required to register under other acts of

\footnotetext{
${ }^{57}$ From 43 per cent to 70 per cent since 1971.

58 The World Bank report (2006, p. 13) says that civil society in Bangladesh consists of "approximately 45,000 clubs, local-level organizations, religious organizations, foundations, and development-oriented NGOs that are registered with the Department of Social Welfare. It also takes in national and local trade unions, professional and business associations, and numerous local community-based organizations, the latter including savings, religious, community development, and social welfare groups, many of which may be temporary and informally constituted." The number of NGOs is difficult to gauge. Haque (2002, p. 412) refers to 23,000, Karns et al. (2008, p. 180 ) refer to 19,000 , Zohir (2004, p. 4110) says that guesses range between 22,000 and 24,000 .

${ }_{59}$ Gauri and Galef (2005), report that an estimated $92 \%$ of NGOs said they provided microfinance. The World Bank (2006) report contains similar percentages.

${ }^{60}$ Gauri and Galef (2005, p. 2050) have very similar results - they say that an estimated $99.5 \%$ of all NGOs "reported no religious affiliation". See also Lewis (1997, p. 35).
} 
parliament or to work with other government agencies, such as the Religious Affairs Bureau or the Ministry of Education (Hedayetul Huq, 1999; World Bank, 2006; Zohir, 2004). There are currently 2161 NGOs, both national and international, registered with the NGOAB (Non-governmental Affairs Bureau, 2012b). NGOs may also be registered with the Association of Development Agencies in Bangladesh (ADAB), a voluntary non-governmental regulating body. In 2004 there were 2152 NGOs registered with ADAB (World Bank, 2006, p. 13). Regulatory changes have affected Christian mission organisations in Bangladesh.

Currently many denominational and non-denominational mission organisations from countries in the Global North, ${ }^{61}$ are active in Bangladesh. ${ }^{62}$ Mission organisations are required to register with various government agencies. All missions who receive international funding (i.e. any who have missionaries who are not Bangladeshis) must register with, and report on activities to, the NGOAB. In September 2012 the NGOAB listed 23 organisations with the word mission in their registered name, ${ }^{63}$ and four who included 'missionary'. A further 11 organisations had 'Christian' in their registered name (Non-governmental Affairs Bureau, 2012b). ${ }^{64}$

Registration with the NGOAB does not give a comprehensive overview of missionary activity in Bangladesh. Some missionary organisations may support missionaries employed by local or international business interests. Other missionary activity in which participants were involved was implemented through

\footnotetext{
61 There is globally a noted, though slow, increase in missionaries from countries in the Global South (Bonk, 2006; Interserve International, n.d.-b; Rieger, 2004).

${ }^{62}$ Mission organisations are made up of sending and service agencies, both "working towards the same goal, conversion to Christianity" (Hearn, 2002, p.54). Denominational mission organisations are established by a specific denomination such as the Catholic church, or the Anglican Church. They may be country specific. For example the Anglican Mission's Board of the Anglican Church in Aotearoa/New Zealand and Polynesia is an umbrella organisation which supports the New Zealand Church Missionary Society (NZCMS). NZCMS missionaries may however work with missionaries from other Anglican provinces worldwide. Non-denominational mission organisations are not affiliated with any specific church denomination, they will accept and send missionaries from many different churches (though often from a protestant, evangelical or Pentecostal background). They may have a statement of faith which missionaries are requested to adhere to, for example see Serving in Mission (SIM) or Interserve International.

${ }_{63}$ This includes organisations who were clearly, Muslim, Buddhist or Hindu as well as some that were ambiguous. There were 13 unambiguously Christian who used the word 'mission'.

64 This includes Development organisations such as Christian Aid, who would plausibly wish to disassociate themselves from missionary activity.
} 
a local church and instigated by Bangladeshis and therefore would not have needed to be registered with the NGOAB. ${ }^{65}$

The power dynamics between the non-government sector and the government has been influenced particularly by NGOs relationships to external funding sources (Stiles, 2002, p. 840). In the 2011-2012 financial year, the total approved overseas funding for NGOs active in Bangladesh was US\$939,293,725.89 (Non-governmental Affairs Bureau, 2012a). In addition to power dynamics over funding, the relationship between government and the NGO sector has been shaped by various Islamic beliefs and practices in Bangladesh. Islamic-based protest flared up in the 1990s with activism against mainly Bangladeshi NGOs such as BRAC for purportedly promoting anti-Islamic activity (Gauri \& Galef, 2005; Rashiduzzaman, 1997; Stiles, 2002). Some protest also contained anti-Christian sentiments (Rashiduzzaman, 1997).

It has been argued that increasing Islamic fundamentalism in politics, fostered by military dictatorships and a move away from the secular state has placed pressure on the Christian communities in Bangladesh, resulting in tighter government regulation of churches during 1980s and 1990s (Stanley, 1992, p. 434). As a result some missionary activity has been more tightly controlled and some missionaries were forced to leave Bangladesh. This period of increasing regulation and Islamisation (White, 2012) has had a profound effect on missionary organisations and has influenced the focus and activities of these missionaries in a variety of ways.

\section{Current Christian mission in Bangladesh}

The activities of missionaries and missionary organisations in Bangladesh vary widely. As identified above, missionaries in Bangladesh have traditionally been involved in the provision of education and health services. Missionaries were also active in church planting, proselytization, discipleship programmes, and theological training. These activities have been adapted in response to government and popular pressure, outlined above. Missionary approaches have also changed in response to mission paradigms. Currently holistic mission plays a dominant role in some mission organisations. These changes and pressures were reflected in participants' stories.

\footnotetext{
${ }^{65}$ One participant said the organisation she worked for was not registered as an NGO but it was
} their aim to become so. 
Missionaries are still involved in health and education service delivery. In this research three participants were teachers in some capacity (two were English language teachers). As NGO regulation has increased in Bangladesh many mission organisations have adapted to fit government requirements, particularly in forming development NGOs. Several participants identified themselves as NGO workers involved explicitly in 'development'. For other participants government pressure resulted in work outside of the NGO sector, particularly in business.

\section{Conclusion}

'Mission' and 'development' vary considerably over time and space. The context of Christian mission in Bangladesh is shaped by the history of the church in mission, by current missionary paradigms and by the historical, political and social background of Bangladesh.

In this chapter I noted that colonial history resulted in a high number of NGOs and Christian mission organisations operating in Bangladesh. This led to government regulation in the sector influencing who can work in Bangladesh, and what activities can be undertaken. Regulatory changes effected what missionaries can and cannot do and may be influencing perceptions among participants spoken to of what a missionary is. Within this context missionary organisations have adapted and moved towards an NGO framework, in many cases with a specific 'development' basis.

I also noted that missionaries operate within a theological framework which has changed over time. The current focus of many evangelical mission organisations is on 'holistic mission'. An approach which purports to respond holistically to the message of Christianity and which spreads this message through social and evangelical means. Theological change is one aspect in the multiple debates which informed participants' actions and arguments.

Carole Rakodi writes that any analysis of religion and development

must be contextualised, because the understanding and practice of religion and the experience of development are both strongly influenced by the historical, political and social context in which they evolve (2012a, p. 648). 
In this chapter I demonstrated how the context of Bangladesh (particularly the history and the current activities of missionaries), and the context of mission (particularly theological changes) influenced how missionaries as religiously motivated actors work in Bangladesh. These contexts are significant in shaping how development and mission interact. They also provide a backdrop for the discussion to follow on the aims and motivations of the people with whom I spoke. Placing the stories of these participants within this context demonstrates how mission and development are mutually informed, and how the distinction between mission and development can be hard to identify; points I return to in more detail in the final chapter. 


\section{Chapter five: Participants' stories}

\section{Introduction}

This chapter presents my interpretations of participants' stories about who they are and what they do in the context of ideas introduced earlier concerning Christian mission, development worker identity, and the context of Bangladesh.

Firstly, I introduce the people in this study and begin to consider their stories. In an attempt "to 'describe', but not reify" (Cook, 2007, pp. 12-13) participants, I identify six facets of their subjectivity and explain why these 'facets' were important in this study. I follow this analysis with some detailed reflection on what they do in Bangladesh. Through this introduction I discuss participants' different concepts of mission. I also acknowledge briefly how the political and cultural context of Bangladesh has shaped how mission and development interacted in the lives and work of these particular participants.

Secondly, I take a more in-depth look at participants' stories. I discuss their motivations for working in Bangladesh, particularly stories about 'calling' and going 'over there'. I refer particularly the work of Barbara Heron (2007) to examine participants' stories (see also Cook, 2007; Eriksson Baaz, 2005; Stirrat, 2008). As Heron notes

for participants coming from a strong Christian background, faith both simplifies and complicates altruistic motivations. The belief that this is 'what God wants us to do' [...] is in a sense beyond contestation. Yet it allows the same elision of power relations, even when inequality is acknowledged (2007, p. 45).

I examine ways in which faith 'simplifies and complicates' participants' motives and actions. I contend that participants, like many missionaries, are shaped by colonial continuities, understandings of the 'helping imperative towards Others', and also by Christian narratives. I reflect on what these stories illustrate about the mission-development nexus and argue that participants were situated, often in apparently contradictory ways, in both mission and development discourses.

Thirdly, I examine the aims of the missionaries with whom I spoke. These aims were primarily seen as 'sharing', 'helping', 'being an example', 'modelling', and 'teaching'. I explore how participants used these words and how these ideals informed the practice of their missionary subject positions. I compare these aims 
with analyses of development workers' activities and accredited aims. Through this comparison, I explore how understandings of God or faith may simultaneously 'complicate' and 'simplify' participants' stories, particularly when they participate in development work. I ask what the implications of this analysis are for understanding 'mission' and 'development'.

\section{Who were the participants and what did they do?}

During my research fieldwork in Bangladesh I interviewed 11 people about what they did in Bangladesh and how they understood 'mission'. In this section I relate what participants said about what they do. Table one summarises some facets of 'missionary' subjectivity as represented by participants in this study.

Table 1: Facets of participants' subjectivities

\begin{tabular}{|c|c|}
\hline $\begin{array}{l}\text { Religious } \\
\text { background }\end{array}$ & $\begin{array}{l}\text { All participants were evangelical Protestant in faith background } \\
\text { and current practice; within this were nuances of practice and } \\
\text { belief. }\end{array}$ \\
\hline Occupation & $\begin{array}{l}\text { Eight participants worked for NGOs in Bangladesh; of these three } \\
\text { were teachers, one an engineer, one a social worker, and three } \\
\text { were 'community development workers'. Christina and Ben were } \\
\text { working for Bangladesh-based businesses. Joy was a full time } \\
\text { mother. All participants could also be described as full time } \\
\text { 'missionaries'. }\end{array}$ \\
\hline Nationality & $\begin{array}{l}\text { One participant was a Bangladeshi national. Seven were North } \\
\text { American, one a New Zealander, one Australian and one } \\
\text { British/American. }\end{array}$ \\
\hline Gender & Four men and seven women were interviewed in this research. \\
\hline $\begin{array}{l}\text { Mission } \\
\text { organisation }\end{array}$ & $\begin{array}{l}\text { Katie and Julie were not with a specific mission organisation and } \\
\text { were supported by their churches. The remaining nine were with } \\
\text { six different international non-denominational mission } \\
\text { organisations (there was some overlap between organisations). }\end{array}$ \\
\hline $\begin{array}{l}\text { Location in } \\
\text { Bangladesh }\end{array}$ & $\begin{array}{l}\text { Joy, Ben, Katie, Michael, Anne, and Mark were located outside of } \\
\text { Dhaka. Sophie, Julie, John, Kathryn, and Christina were based in } \\
\text { Dhaka. Sophie and John were involved in projects in rural/semi- } \\
\text { rural locations. }\end{array}$ \\
\hline
\end{tabular}

Religious background was the most significant 'facet of subjectivity' as participants understood and responded to their evangelical background in various (largely similar) ways. Occupation became apparent as a defining aspect of participants' subjectivities as tensions between officially permissible 'roles' (such as NGO worker) and unofficial and unpermitted 'roles' (such as 'missionary'), 
were discussed. Nationality emerged as some participants described how they felt being a 'bideshi'. These reflections were also interspersed with how they constructed a (Bangladeshi) 'Other' in opposition to self and what 'race' meant to them. Furthermore in the discussions about relationships (a significant part of their work) participants identified 'barriers' and 'tensions' which emerged from their 'western'66/bideshi subjectivities. While gender was not discussed directly in relation to this research it emerged as a significant facet of subjectivity as participants, both men and women, spoke of the 'difficulty' of being a (white) woman in Bangladesh.

I have included organisational identity as it played an important part in defining what people did in Bangladesh and how they identified their work. For example participants working for clearly defined development NGOs had a stronger emphasis on 'holistic mission' than participants whose work was not identified as 'development'. Furthermore organisational identification often revealed participants' ambiguities in identifying and acting as a 'missionary' and as an NGO worker, development worker, business worker (i.e. 'not a missionary').

Most participants queried my use of the word 'missionary'. Joy said "you know ... I hardly use that word anymore" (2011, Joy interview, 29 Nov.). Later she said "I don't know - if missionary were more clearly defined then maybe I would be happier being called a missionary" (2011, Joy, pers. comm., 27 Nov.). Sophie acknowledged how missionary work had changed. She said that the word missionary was an "archaic term these days" (2011, Sophie interview, 20 Dec.). Participants also acknowledged government regulations which restricted their 'missionary' identification.

Participants work ranged from tangible activities, such NGO work, to the more intangible activities, such as prayer or discipleship. Participants' were employed in a range of jobs. In the NGO sector as a social worker (Kathryn); engineer (Michael); community development worker (Julie, Sophie, John); and teacher (Katie, Anne, Mark). In the private sector Christina was a manager and Ben a designer.

\footnotetext{
${ }^{66}$ I use 'western' in certain places when describing participants to indicate that I or participants are referring to "particular cultures and systems of thought, originally centred in Europe and exported through colonialism to the Americas, Australia and New Zealand" and that these thought systems are based on Greco-Roman and Judeo-Christian cultures that evolved in Europe through the renaissance, Enlightenment and imperialism (McEwan, 2009, p. 14).
} 
In some cases these occupations reflected only the more formalised aspects of their work. In response to wider questions about what it meant to be a 'missionary', participants described a variety of activities which they considered to be part of their 'missionary' work. These included prayer, spending time with and supporting Bangladeshi people, producing Christian literature resources, 'hanging out', and leading, or going to, Bible studies.

For many people, prayer and other elements of their Christian life and practice were important aspects of their work. Katie spoke about praying "just everyday asking 'God, give me opportunities, how can I show your love?'” (2011, Katie interview, 8 Dec.). Ben said "I feel like what we're doing is just being Christians here" (2011, Ben interview, 30 Nov.) while Joy said it was about 'living it every day! Every day! .... It isn't a job and it isn't your leisure, it is your whole life' (2011, reflective journal, 22 Nov.). These, sometimes less concrete, activities were nonetheless significant. At one Bible study and team meeting that I attended, one missionary (who was not interviewed formally) spoke about how their purpose was “'being', not 'doing”' (2011, reflective journal, 1 Dec.).

The specific context of Bangladesh also contributed to changes in the activities of participants. Tightening government regulation made it difficult for participants to officially work as missionaries in Bangladesh, contributing to (but was not the sole cause of) an increase in development NGO-type activities among participants. As a result NGOs played a significant role in what participants did. For some, involvement in NGOs was a pragmatic response to government regulation, for other participants involvement in NGO work was theologically motivated (particularly John and Christina).

A key topic of conversation among many of the missionaries in Bangladesh with whom I spoke (including those not interviewed) concerned strategies for getting a visa. For many their approach was to register as an NGO worker, and sometimes also to establish an NGO. Many of these NGOs had legitimacy with the local population and had clearly articulated aims; others were less well-defined, and seemed in some instances to be a 'cover' for activities that could be more typically associated with mission. All participants argued that their missionary role was holistic, requiring integration of emotional and physical aspects of life and work, and most importantly, that their activities (even if NGO or 'development' based) were also spiritually based and motivated. 
The practical descriptions of what participants did illustrated the overlapping ways in which mission and development were enacted in their lives within the specific context of Bangladesh. Participants' activities demonstrate the tension the experienced acting within a mission-development nexus. Participants demonstrated how they were simultaneously 'development' actors and 'mission' actors.

\section{Participants' motivations: why are they in Bangladesh?}

\section{Origins of the missionary and the development worker}

It is important to place participants' stories in a historical context, as Heron (2007) has done with development worker identity. Heron (2007) argued that development worker identity emerged within Enlightenment concepts of the individual, the superiority of the 'West', and the colonial endeavour. Similarly, current (western) Christian evangelical mission paradigms formed in this environment (Bosch, 1991), as was noted in chapter four.

Heron (2007) writes that colonial continuities in development worker narratives can be understood by tracing how bourgeois, or middle-class, subjectivity was formed. She argued that the origins of development workers subjectivity are found in the emergence of the bourgeoisie in Europe in the early nineteenth century. The bourgeoisie were "raced, gendered, and superior, with a planetary consciousness that assumed the right to intervene in any part of the world" (2007, p. 28). According to Heron, bourgeois identity was formed through "moral regulation" of the self ( 2007, p. 30 , italics in original) and the construction of a morally deficient Other who required bourgeois intervention

Others needed to be civilised, through governance, education, and learning how to live and what to desire in bourgeois terms since this represented the highest achievement of civilization [emphasis in original] (Heron, 2007, p. 30).

Noteworthy to my research is how this 'civilising' process interacted with a 'Christianising' process (Heron, 2007; McEwan, 1994). Cook has noted that the 'helping imperative' is "linked to ventures in the colonial past" and

overt missionary conversion in the colonial era ... has a legacy in contemporary international development because similar ideas and representations organize their practices. While they are different global mechanisms with particular trajectories, they are 
characterized by overlapping histories of global domination (Cook, 2008, p. 24).

Likewise, Kothari argued that generalised colonial continuities may be seen in the activities and language of "international 'cooperation' and aid" and advocated discussion on "how these may be racially inflected" (Kothari, 2006a, p. 13). She traced the construction of racialised Others in the colonial enterprise and examined how this continued in development. She wrote

by sustaining, for example, the 'traditional' versus 'modern' dichotomy, mapped onto third and first worlds, respectively, development becomes a racialized project drawing upon a colonial imaginary when identifying who and what is 'progressive'/ 'backward' (Kothari, 2006a, p. 13; see also Crewe \& Harrison, 1998; Kapoor, 2008; Said, 2003 among others).

As noted in chapter four, significant aspects of the Enlightenment such as belief in reason, progress, and modernisation entered and were adopted by the Christian church. David Bosch writes that

through knowledge and education, benevolence and charity would be spread far and wide ... [and consequently] ... God's kingdom became increasingly aligned with the culture and civilisation of the West (1991, p. 271).

Similarly David Bebbington argues that the emergence of evangelicalism "was itself an expression of the age of reason" as the protestant tradition "adapted ... through contact with the Enlightenment" (Bebbington, 1989, p. 53). Bebbington also notes that good works were a significant part of evangelicalism and that this gave rise to "an empire of philanthropy in the nineteenth century" which was that "entirely in harmony with the spirit of an age that set benevolence among its highest values" (1989, p. 71).

Early protestant missionary societies were formed in periods of religious revival and were initially concerned with both the salvation and the physical conditions of people in Europe, the United States, and in European colonies (Bosch, 1991, p. 281). Although early evangelical missionaries were often unwelcome in colonial regions, Bosch writes that "gradually evangelicals became a respected power in the state, and missionaries, whether they intended to or not, became promoters of Western imperial expansion" (1991, p. 282).

According to Bosch (1991) the missionary 'motif' of this colonial period was understood as to be 'constrained by Jesus' love'. This motif linked the 
humanitarian with the soteriological and was seen in condescending attitudes towards the 'heathen savages' who must be converted, thus "love ... deteriorated into patronising charity" (Bosch, 1991, p. 290). Through this condescending benevolence those with (spiritual) wealth

were morally obliged to share their spiritual wealth with others; and they alone were equipped with power from on high and had help to offer to those sitting in darkness and the shadow of death .... The pagans' pitiable state became the dominant motive for mission, not the conviction that they were objects of the love of Christ (Bosch, 1991, p. 290).

I believe that it is from this legacy that evangelical missionaries still, often unconsciously, operate. Through this mission paradigm the colonial continuities spoken of by Heron (2007) are seen in the missionary stories from participants.

Many participants in Bangladesh recognised the colonial association with mission and attempted to move away from it, however the practices of their faith and the missionary heritage in which they were deeply imbricated made this very difficult (see also Bonk, 2007). Their good intentions and the way they changed the language they used was not necessarily enough to change practice. As will be demonstrated in the ways in which participants spoke of their 'calling' to Bangladesh, and their 'sharing', going 'over there' reflected a desire and mandate to "confer salvation in those who accept certain tenets of the faith" (Bosch, 1991, p. 228), reflecting Heron's (2007) analysis of entitlement and obligation in development workers' stories.

Although some participants acknowledged the historical location of mission in colonialism, and consequently moved to reject the word, most did not analyse the mission process further. Some participants did not explicitly critique their actions but acknowledged the tensions they felt in being missionaries in Bangladesh, and reflected on their continued presence in Bangladesh in the light of this colonial history, particularly in reference to money and power. The shared history of missionaries and development workers was evident in participants' stories about calling and sharing discussed below. 


\section{'Called' by God to Bangladesh}

Almost all participants described feeling like God had asked them or told them to go to Bangladesh. This was often described as being 'called' or 'sent'.

Mark, from the United States of America, ${ }^{67}$ said

ultimately I am here because I know God wants me to be here. ... That was a very clear call. ... It's not the vocational or the geographical issues that brought me here ... it's faith in Christ. And I sensed a very strong call ... that I belong in Bangladesh (2011, Mark interview, 28 Nov.).

Likewise, Sophie, also from the States, said that

the Lord basically spoke to me. I didn't hear anything else. There was no noise around me and all I heard the Lord say at that moment was 'now is the time, I want you to go.' And I thought, 'ok, Lord, what does that mean?' you know, 'what are you talking about?' I guess I had always thought I would be open to the idea of living overseas and working overseas but I never imagined myself as a missionary at all (2011, Sophie interview, 20 Dec.).

Similarly, Julie, from Bangladesh, said that when she first decided to work in Christian ministry

my first thought is 'ok, I don't want to do ministry in Bangladesh. Lord, don't send me Bangladesh. Any other country'. [I] said to God 'send me [to] Afghanistan, no problem, but don't send me [to] Bangladesh’ (2011, Julie interview, 14 Nov.).

When Julie realised that God was calling her to Bangladesh she said "[God] asked me to follow his [sic] footsteps ... I am just obeying [God]" (2011, Julie interview, 14 Nov.).

Finally, Katie, from Australia, said

I guess ... for many years I felt God call me to the mission field, to a third world country.

... l've kind of felt God talk to me ... like watching something on TV, or through somebody talking about something about what they're doing overseas or something. ... Something in my heart always kind of ... I don't know ... like I want to be there too. I want to help. And I feel God over time has shown me that that's what he [sic] wants for me. And through different situations l've felt God, I guess, ask me in a way ... 'will I go?' Will I go and be his [sic] hands and feet and just serve wherever he wants me.

\footnotetext{
${ }^{67}$ From this point I refer to the States or the USA for ease of reading.
} 
Yeah ... just seeing that there're so many people out there that don't have that much in the way of even food or clothes or just the basics ... that I just take for granted.

I felt God for many years prepare my heart ... to live overseas in a third world country, working with poor people. And ... l've been to Africa short term, just two weeks, and China for two months ... and Papua New Guinea for two weeks .... At the same time it was just kind of a stepping stone. And now coming to Bangladesh ... I just feel, yeah, this is where God wants me ... I don't know for how long but it's just a peace in my heart (2011, Katie interview, 8 Dec.).

When Katie spoke about why she was in Bangladesh it was clearly a faith-based decision. God spoke to her and she had a 'peace in [her] heart' that she was where God wanted her to be.

'Calling' was central to these participants' decisions to live in Bangladesh. However, their stories show that other discourses also shaped their choice. Some of these other discourses were seen in Katie's explanation of how she came to be in Bangladesh.

Katie's description of God's calling was explicitly connected to a place 'there', the 'mission field' and a 'third world country'. Katie referred to watching TV, or hearing people talk about 'overseas' experiences. She linked going to live in a 'third world country' with people who "don't have that much in the way of ... just the basics" (2011, interview, 8 Dec.). Katie displayed what Heron (2007) called 'planetary consciousness' or global awareness in her descriptions of over there. As in Heron's (2007) analysis, her 'planetary consciousness assumed a 'right to intervene'. She connected descriptions of Bangladesh and 'a third world country' with her reason for becoming a missionary and her desire to 'help'.

Heron argued that in development workers' stories the language of 'planetary consciousness' was dominated by "entitlement and comparative superiority" (2007, p. 26). Likewise, in Katie's story her desire to 'help' is based partly on her perception of the impoverishment of people 'out there'. Finally, Katie's moral imperative was supplemented by her spiritual imperative. In her story God called her to be "his [sic] hands and feet" (2011, Katie interview, 8 Dec.). In Katie's story the spiritual and physical justifications for intervention 'over there' were closely connected. 
When Anne, from the States, talked about why she became a missionary she referred to a Bible verse describing Jesus' life on earth

it said that God became flesh and dwelled among us ... and I think one of the contemporary versions of that says he ... took on human skin and moved in to the neighbourhood ${ }^{68} \ldots$ and the idea of a missionary is like taking, um, carrying Christ with us into a neighbourhood ... just like God came and dwelled among humans he [sic] calls us to go and ... and be bearers of his word, his love ... all of that (2011, Anne, interview, 28 Nov.).

For Anne, to be a missionary entailed "moving into the neighbourhood" somewhere else, just as Jesus left heaven to live to earth. Moving into a neighbourhood may be an attempt at solidarity, however in Anne's story it also entailed going away from her own neighbourhood as 'bearers of his [God's] word' (2011, interview, 28 Nov.).

A similar analysis of calling and the nature of 'over there' can be seen in Michael's description of being called to work in Bangladesh. For Michael there was

a feeling in a sense [that] ... when you keep your relationship to God in a right manner that God is going to direct you, and God is going to guide you. ... So I feel like I'm in the right place. And in that sense, yeah, I feel like God has called me here ... I would put it more directed me here because of how he's gifted me as well as the opportunities that are here is like a match between my gifting and ... the needs of the situation (2011, Michael interview, 3 Dec.).

Like Katie, Michael referred to the 'needs of the situation', and in doing so alluded to narratives that construct a place in need 'over there'. Michael worked for an NGO in Bangladesh recognised as specifically 'development' focussed. Thus when he discussed the 'needs of the situation' he also appeared to refer to discourses of global development.

Michael's invocation of a Christian God who directed followers in this way extends similar patterns to the development workers interviewed by Heron (2007). The concept of calling is extremely powerful, and, like Heron's analysis of development workers' justification for intervention, is based in "entitlement and

\footnotetext{
${ }^{68}$ Her quote is from John 1:14 (New International Version (NIV)) "The Word became flesh and made his dwelling among us." Her original quote was from The Message, "the Word became flesh and blood, and moved into the neighborhood [sic]."

Retrieved 5 June, 2012, from http://www.biblegateway.com/.
} 
obligation" (Heron, 2007, p. 52), however it also rested in a Christian narrative where God 'calls' people to do God's will.

There are two common understandings of Christian 'calling' which I now discuss in more detail to deepen my analysis. The first concerns the nature of calling as applicable to all Christian believers. The second concerns a specific (usually understood as 'more spiritual') calling to a distinct task. This sense of calling is important in current evangelical missionary paradigms, and emerged from within key elements of the Enlightenment including colonialism.

\section{The Christian concept of calling}

As noted above for many participants a sense of calling from God was an important reason for going to Bangladesh. Os Guinness writes that 'calling' is

the truth that God calls us to himself [sic] so decisively that everything we are, everything we do, and everything we have is invested with a special devotion and dynamism lived out as a response to his summons and service (2003, p. 4).

He further says that for Christians, Jesus said "follow me" so the ultimate calling is to 'follow Jesus'.

In the Bible 'calling' straightforwardly means to call out to or call upon (Guinness, 2003, p. 29). However to call also means "to name, and to name means to call into being or to make" (Guinness, 2003, p. 30). Thus calling "is not only a matter of being and doing what we are but also of becoming what we are not yet but are called by God to be" (Guinness, 2003, p. 30). In the New Testament calling became "almost a synonym for salvation" as Jesus 'called' his disciples and supporters to follow him and be saved. Finally, Guinness argued, calling is a command when God "calls people to himself [sic]" (2003, p. 30). Thus to be a Christian is to be 'called' to God.

According to Guinness, Christians are primarily called to God, not to do anything or go anywhere. Christians may be secondarily called to do something or go somewhere, but the primary calling is always to God. In this way all work and all activity as a Christian could be understood as calling (Guinness, 2003, p. 41). In spite of this recognition that 'calling' extends to all aspects of life many "still identify real Christians with clergy and missionaries called away from ordinary, creation work by Christ's call to evangelistic or Kingdom work" (Preece, 2010). This calling away from the local and every day to the distant missionary 'field' 
was clear in some participants' stories. For these participants being called was to leave a home country and go elsewhere to serve God.

Guinness (2003) argued that Christian were also called to also use their gifts or skills to the best of their ability for God's purpose, or the glorification of God. Susan Classen, describes her decision to work in development for the Mennonite Central Committee (MCC) as "my sense of call gives priority to using my gifts for the good of the poor. Where and how I do that is open to change" (cited in Yoder, Redekop, \& Jantzi, 2004, p. 73). This aspect of calling, involving using skills and gifts was also reflected in the narratives of participants, such as Michael. Understanding of how best to use gifts and skills varied. It was not necessarily paternalistic, where one person's perceived superior skills and gifts serve another person's perceived inability. However when enacted in the context of other narratives of colonialism and westernisation it could easily become so.

The connection between calling and colonising may be heightened by a littleconsidered aspect in participants' stories, namely the cultural context in which a call was received. In participants' stories of calling their cultural context (western, evangelical Christian) was not considered part of the context of God's calling. Neglect of the cultural context of calling may have led participants into paternalistic attitudes towards Bangladesh in which they were 'called' to work.

Calling in participants' stories often required going 'over there'. The notion of going 'over there' has been strongly criticised by Jonathan Bonk who argued that

the missionary movement from the West must trace the still prevalent assumption that Christian mission is 'out there somewhere'.... This notion ... is implicit and even explicit in many contemporary western evangelical churches, which find it well nigh impossible to disentangle their Christian identities from their deep nationalistic conditioning [emphasis in original] (Bonk, 2007, p. 343).

In addition 'over there' was often constructed as a place to endure, 'over there' was presented in participants' stories as 'different' and also subtly 'lesser than' life back home. For example when Sophie said

I have to use the word different. Life here is different. It's not dumb. It's not wrong. It's not stupid. It's just different. Dress is different, food is different, house is different. You know, relationships are different. Everything about being here is different. Um, and if I can ... if I can help wrap myself about that concept and realise that it's 
different, I'm able to survive more (2011, Sophie interview, 20 Dec.).

Participants' stories of 'surviving' and 'hardship' are connected with discourses of sacrifice and altruism, as discussed below.

\title{
Sacrifice and altruism
}

Historically Christian mission is connected to personal narratives of sacrifice and altruism. This was referenced by participants. Sophie said

\begin{abstract}
there's this connotation, I think, when you say the word missionary that you're going to take all of your belongings, which is very little, and you're going to live amongst the culture which you're ministering to and you somehow disassociate yourself with your own culture, and you eat, sleep and breathe this new culture ... [and] your main purpose is to win souls for Christ (2011, Sophie interview, 20 Dec.).
\end{abstract}

Sophie's comments referenced attempts to achieve heightened spirituality through sacrifice. This claim is seen in Sophie's comment when she describes the perceived sacrifice that missionaries make: they take their few belongings and live in a different (and 'lesser') culture, disconnecting from old lives for the spiritual (and often physical) benefit of other people.

Notions of sacrifice are evident in many of the heroic missionary biographies. ${ }^{69}$ Guinness described calling an understanding that "Jesus calls his followers to ... to suffering, and to service" (Guinness, 2003, p. 30). Sacrifice is also prevalent in development workers' narratives. For example Stirrat (2008) has discussed how sacrifice is an important aspect of NGO workers' identity. Development work purportedly requires

a sacrifice of self in the pursuit of some greater goal. And thus the image conjured up of the NGO worker is of someone enduring privation, of sharing suffering and poverty with the poor of the world, of being actively involved in a direct and unmediated way with the poor (Stirrat, 2008, p. 412)

Similarly Fechter connected discourses of altruism to spiritual gain in development workers' stories. She writes,

this notion of altruism shares with other, faith-based belief systems an assumption that the result of one's actions will be beneficial for the aid-giver insofar as 'pure' altruistic behaviour contributes to

\footnotetext{
69 See for example Elizabeth Elliot's (1987) biography of missionary Amy Carmichael titled, $A$ Chance to Die: The Life and Legacy of Amy Carmichael.
} 
their own spiritual gain. In such belief systems, to be accorded spiritual value, the act of helping must be as free from self-interest as possible. The more pure the compassion, the more valuable it is, and will bring the helper closer to redemption. In the present context this may be a reason for aid workers' unease, insofar as 'living well' while 'doing good' implies that the acts of altruism are less pure-tainted by the material benefits one gains-and therefore accumulate less spiritual or moral value for the aid giver (Fechter, 2012a, p. 1481).

Participants' stories augmented elements of sacrifice and altruism by introducing a spiritual motive. Judy Han describes how South Korean Christian missionaries on short-term mission trips "reproduce evangelical-capitalist subjectivities through structures of journey and hardship" (2011, p. 155). Likewise Fechter writes how development workers create themselves as "more virtuous, and often more spiritual" people "through charity work" (2012b, p. 1393). For participants in Bangladesh, missionary activity may have been a way of constructing more spiritually 'legitimate' subjectivity from foundations in bourgeois subjectivity.

As seen in the quote above, Sophie expressed discomfort with this sacrificial representation of missionaries, and wanted to disassociate herself from it. She refuted the image of self-sacrificing missionary, however as mentioned earlier, she demonstrated links to narratives of sacrifice when she spoke of how she managed to "survive" in Bangladesh (2011, Sophie interview, 20 Dec.) (see also Cook, 2007).

When other participants spoke of 'the mission field' or a calling 'over there' they too demonstrated claims to a heightened spirituality achieved through sacrifice. Mark said he made it "clear to God that I didn't want to go anywhere that ... had a lot of mosquitos or a lot of heat" (2011, Mark interview, 28 Nov.). Similarly Katie discussed going to a "third world country [and] working with poor people" (2011, Katie interview, 8 Dec.), and in another conversation she talked about how she always thought of the World Vision type pictures (presumably those depicting extremely malnourished childre ${ }^{70}$ ) when she imagined working in Bangladesh (2011, reflective journal, 7 Dec.). Discourses of altruism were also evident in participants' stories about what they did in Bangladesh, as discussed below.

\footnotetext{
70 The use of images displaying extreme conditions of poverty or malnutrition, particularly in nonwhite children, in development NGOs marketing material has been and continues to be critiqued by many, see Dogra (2007), Clark (2004), Hutnyk (2004), Radley and Kennedy (1997).
} 


\section{Participants' activities - what did they do in Bangladesh?}

When participants spoke about what they did in Bangladesh the words that emerged repeatedly were 'sharing', 'helping', 'modelling', and 'teaching'.

Joy, from the States, said,

I just love sharing my faith.... I was just a really sad fearful person. And God changed my life.... We're both [talking about her dad] just really messed up people, and God had mercy on us. And ... it's something we're sharing. That's all really.

I would see in God healing people ... and changing people's lives and I know that God has done that in my dad's life and many other people's lives. And so it's like ... if I love people l'm not just going to sit around and let them ruin their lives? I'm going to share with them what I have found to be healing and changing for me (2011, Joy interview, 29 Nov.).

What participants' did and how they did it was "a direct outworking of, and inseparable from, their religious convictions" (Bradbury, 2012, p. 107). However, 'sharing', like 'calling', was also connected to discourses of expertise, paternalism, and development. Participants justified their presence in Bangladesh because they had (western) resources, skills, and (significantly) faith needed to develop Others. Participants 'sharing' did not necessarily lead them to question why inequalities existed but rather it tended to reinforce a need for missionary skill or faith to 'save' or 'help' Others.

Michael said,

[people in Bangladesh are] suffering and they're hurting and they have needs and I have resources to meet those needs ... I have abilities and skills and gifts that God has given me so l'm going to use them to help other people [in Bangladesh] (2011, Michael interview, 3 Dec.).

The concept of sharing 'skills and gifts' to address the 'needs of the situation' reoccurred throughout interviews with participants. Participants spoke of 'showing', 'being an example', 'demonstrating', and 'teaching' not only their belief system and how to be a good Christian, but in many cases this also signified how to be a 'good' westerner. Frequently the one seemed to lead to the other.

This notion of sharing is reminiscent of the discourses of expertise used to justify intervention by the 'development expert' (Kothari, 2005, 2006b; Parpart, 1995; 
Stirrat, 2000). Furthermore 'sharing' recalls Heron's (2007) understanding of the development workers' 'moral imperative' to intervene which is shaped by a sense of entitlement and obligation, and a 'desire' for development (2007, p. 43; see also Kapoor, 2008). These writers demonstrate how the language of expertise and the language of altruism merge in development worker stories. In participants' stories altruism and expertise were bolstered by spirituality and religious conviction.

For example, in Michael's story this notion of 'showing' emerged when he spoke about how as a missionary his role involved being a "visible demonstration of the love of God for the people of Bangladesh by what I do, by what I say, by how I live" (2011, interview, 3 Dec.). He also said

you have to model it [being Christian] in the community where the people live and ... [for a Bible study] help them [Bangladeshis] to figure out, well, where we can meet, how we can meet, what time we can meet, who is going to provide the snacks ... details of that kind of stuff (2011, Michael interview, 3 Dec.).

In a similar way Katie talked about

giving them [Bangladeshis] hope for the future, and loving on them $\ldots$ and whatever gifts or talents l've got just helping them to be better people ... and showing them Jesus and God and ... how God can help them (2011, Katie interview, 8 Dec.).

According to her, teaching Bangladeshis about "character, or first aid or their environment, the country or something" could "open their eyes a little bit more ... to things they probably don't think about that they're doing, like washing their hands after they go to the toilet" (2011, Katie interview, 8 Dec.).These lessons, which Katie said were simple things, still needed her as an external western missionary to activate Bangladeshis to respond and change. Thus it was the active western missionary who had the skills to 'give hope' and 'open eyes', without whose agency Bangladeshi people would neither know God nor 'develop' into 'better people'.

Sophie spoke of

just modelling, you know, in what we say, how we dress, what we do, we are ... much more followers of Jesus than ... than anybody, 
um ... you know, out there ${ }^{71} \ldots$ it's incorporating biblical values, biblical principles into our day to day tasks. ... And being an example [for Bangladeshis] (2011, Sophie interview, 20 Dec.).

Sophie also emphasised teaching and training, from modelling a good marriage in her private life to working with Bangladeshis in an NGO "to train and equip them [Bangladeshis] to get them up to where they need to be as far as their English level [and] their business leadership training" (2011, Sophie interview, 20 Dec.). Her emphasis reflected ideas about modernisation, progress, linear development, and the role of the 'westerner' (or 'development expert') which, for her, was to bring her Bangladeshi colleagues up to an ideal western level (see also Crewe \& Harrison, 1998; Kothari, 2005, 2006b; Parpart, 1995).

Sharing or modelling occurred on the development level, however, Sophie included a specifically religious aspect to her work when she said "we want to teach them to pray on their own" (2011, interview, 20 Dec.). In this statement she implies that Muslim Bangladeshis don't already pray on their own or that they don't do this in an appropriate or recognisable way to her. ${ }^{72}$ Furthermore, Sophie went on to say that it is "our responsibility as ... Christian[s] to ... share good practices with people" (2011, Sophie interview, 20 Dec.), as if white Christian missionaries held the good (religious and social) practices and, out of benevolence and Christian duty, should share them with Bangladeshis less fortunate than themselves.

As noted in chapter two, studies of development workers have explored the concept of expertise and argue that the development 'need' for technical expertise contains paternalistic attitudes towards a once colonised Other and is applied to reinforce power inequalities between what is perceived to be the technical and industrialised west and an undeveloped rest (Kothari, 2005, 2006b; Parpart, 1995; Stirrat, 2000). The paternalism in the language of expertise is also reflected in some participants' stories of 'modelling' and 'showing' how to be a good Christian.

\footnotetext{
${ }^{71}$ She was referring to perceptions of 'western' (mainly American) Christians as being 'like Britney Spears', which she said was common in Bangladesh (2011, Sophie interview, 20 Dec.). Sophie was not explicitly referring to Bangladeshi Christians (though it could be read as implicit in her comment).

${ }^{72}$ Islamic communal prayer traditions are well known; prayer is one of the five pillars of Islam and is very publically present in Bangladeshi life. Another participant commented that she had lived in Bangladesh for several years before she realised that many Bangladeshi Muslims also pray individually and 'unstructured'. Sophie's comment illustrated assumptions about the personal faith and relationship with God that Muslims in Bangladesh are assumed to have.
} 
There was also a tendency among some participants to associate 'missionary' with 'spiritual expertise'. Thus participants discussed how they were in Bangladesh to help the Bangladeshi church grow and to disciple Bangladeshi Christians. ${ }^{73}$ Capacity building, as a common practice worldwide in development NGOs, is emblematic of this process of expertise and demonstrates a continued perception that expertise flows from white and western development worker/missionary to non-white Others. Within the context of Christian mission, this capacity-building can have a spiritual focus as demonstrated when Michael's said he was

sharing with them my skills and abilities ... [so] that they will see God working through that, see God's love expressed in a tangible way in their community, in their lives, and then respond to that love personally (2011, Michael interview, 3 Dec.).

Michael presented himself as someone who held knowledge and skills and was able to intervene. He combined Christian and western narratives of intervention. In doing so Michael and other participants conflated ideas about a 'good' Christian life with those of a 'good' western life.

Michael acknowledged that in missionary activity there is a

cultural imperial [aspect] ... it's the ... rich western white culture coming and telling the poor eastern .... culture of colour that ... all your current ways are bad and wrong and you need to change (2011, Michael interview, 3 Dec.).

His statement indicated some level of resistance to, or acknowledgement of, the historical and institutional grounding of the missionary endeavour. This appeal to more interpersonal engagements nonetheless reflected a western emphasis on individual agency and belief that it was through his (white, western) presence that his Christian God would be revealed to the Muslim Bangladeshis around him

[conversion is] not really what it's all about. ... I'm really about trying to reveal God to these people in a personal way through my presence, through his [sic] word, and then getting them [Bangladeshis] to respond to that (2011, Michael interview, 3 Dec.).

Thus Michael reinforced an inequality, whereby his skills, knowledge and relationship with God empowered him as a conduit of better and more ideal

\footnotetext{
73 There is also a tendency to associate missionary with western Christian, this is changing as South to South missionary exchange increases (Bonk, 2006; Interserve International, n.d.-b).
} 
knowledge. Development has been critiqued within postcolonial analysis as an unequal exchange which reinforces the inequalities it purports to change. Likewise, Michael's missionary approach can be understood as a neocolonial endeavour where others need to, and are able to, become almost (but not quite) like the missionaries there to help, share with, and teach 'them'.

Furthermore, for these participants constructions of power had spiritual implications. Thus, in Michael's story it was when he, the westerner, shared his skills and abilities that God's love was demonstrated. By responding personally to that love, Bangladeshis were seen as able to achieve a similar 'level' of skills, abilities and salvation.

Through an emphasis on the ideals of physical and spiritual conversion (the transferral and adoption of 'skills' and a Christian faith in God) both an idealistic hope for change and a pervasive colonial continuity were held in some participants' stories. On one hand, some participants' desired equal exchange and positive outcomes for Bangladesh, and on the other, their vision of how to reach these points (via spiritual and physical conversion) maintained and perpetuated systems of inequality by emphasising (consciously or unconsciously) white missionary superiority both spiritually and culturally (see also McDuie-Ra \& Rees, 2010).

For example, Mark discussed his NGO work as a place where there would be

two streams of learning going on at the same time, mingling together, so you have a ... cultural exchange going on. And the themes behind all of that, I think, would be so that, maybe Bengalis could have a better perception of westerners ... as they interact with them. And then also I would hope that westerners coming here would have a better perception of especially Muslims, because they have a very negative view of Muslims in the west. ... And then just music being hugely ... a very heart-connecting sort of activity to be in (2011, Mark interview, 28 Nov.).

This 'heart-connecting' activity was a missionary ideal for Mark and many others. Mark hoped for equal exchange instead of a relationship of unequal power. However as can be seen through his following comments his ideal of equal exchange was tempered with a continuing paternalism through which he, as the 'missionary', was the active instigator in "raising the dignity of Bangladesh"

And then I think one of the biggest items on my agenda for the school is that Bangladeshi's realise that instead of ... they're 
always the kind of the focus of development help. And they're ... you know, so obviously ... poor and needy and famine stricken and all these things, and they have a perception of their own country - that we're poor and we're miserable and we need help from the west. Whereas the idea of this school would be, 'no, Bangladesh has a rich cultural heritage'. It's thousands of years old compared to American culture which is 200 years old as far as us western Americans. Um, it's a deep, rich cultural heritage and they have that ... they have a gift to offer the west in ... in the writings of Tagore and the music of the Ragas and all of this ... the Tabla rhythms and things which have taken centuries to develop. So all of this ... I hope would raise the dignity of Bangladesh" (2011, Mark interview, 28 Nov.).

Mark and Michael legitimised their intervention in Bangladesh by applying stereotypes of Bangladeshi behaviour which reinforced asymmetrical power relations. This reinforcement was seen when Mark said that despite the rich musical and literary heritage found in Bangladesh there is an inability to use or celebrate this heritage. His actions were legitimised and his position reinforced when he argued that an NGO, such as the one he was involved in, was able to instigate this pride.

Joerg Rieger writes that "with few exceptions colonial power went hand in glove with the theological authority claimed by the missionaries" (Rieger, 2004, p. 203). Participants' constructed 'inherent inabilities' of Bangladeshis ${ }^{74}$ and responded with technological solutions they and others could provide. These constructions also reinforced ideas about western superiority and produced a colonial Othering. Additionally these constructions confined 'development' to a modernisation trajectory based on western ideals of 'progress', and denied the historical bases for the current situation.

Through reinstatement of western missionary superiority and expertise, western political and economic dominance was "seen as direct proof for the authority of Christianity" (Rieger, 2004, p. 204). Many participants purported to know what was "right for the world" and determined outcomes for those with less power (Rieger, 2004, p. 209).

\footnotetext{
${ }^{74}$ When speaking of the work of his NGO Michael says "there is an inherent limitation in their [Bangladeshi] ability to produce a technology" to deal with a recognised problem, but with the westerners help the technology has been developed for a solution. This kind of stereotyping has been widely critiqued, Bakke has argued that in the past, publications from missionaries presented "stereotypes [which] legitimized the idea that black Africans were mentally, socially, and culturally inferior to the Europeans - who were therefore justified and even obligated to subjugate Africa and to bring the European, Christian civilisation to that continent" (Bakke, 2010, p. 53; see also Crewe \& Fernando, 2006; Kothari, 2006a; White, 2002).
} 
Missionary desire to altruistically 'share' their faith has been questioned by others. Rieger argues that "missionaries meant well; they genuinely wanted to make a difference and wanted to help" (2004, p. 205), an attitude reflected by participants I interviewed. There was an abundance of good intentions, but such a focus on intentions rather than effects is unproductive in changing missionary practice and power relationships.

As seen above, participants' responded to discourses of development, [neo]colonialism, and expertise. However, they also responded to discourses of Christian faith, as can be seen in their activities. For example, one participant, Joy, described a Bible study in which she was involved. For Joy her work was primarily about theology, she said "I believe that teaching people fundamental theological truth will change the generation" (2011, Joy interview, 29 Nov.). Of the Bible study with Bangladeshi women she said,

we have these lovely prayer times when we just say, you know, unless we are filled with the Holy Spirit we are not going to be able to understand these things. ... So we sit around and we breathe in and we just ask the Lord to fill us and change our hearts so we can understand these things. And ... and it happens.

We've seen them learn that they're not up to their chests in hell and that they're not more lustful than men. And I think that's ... that's changed them.... It's hard to track you know. Like what theological belief that they finally understood made them do what? (2011, Joy interview, 29 Nov.).

For Joy it was necessary that the Holy Spirit was present with these women in this place for transformation. However, during this Bible study women helped themselves and each other with practical and physical issues. Joy said

Since I have known them they have learned how to sew more. They've also just helped each other with health issues, with sprained ankles and arthritis, and vaginal infections and fevers and colds and stuff. There's a good sharing of information that happens in those times that I hope has been most beneficial to them (2011, Joy interview, 29 Nov.).

In this Bible study "the activities more easily identified as 'development' had a dependency upon the activities more easily identified as spiritual" (Sanderson, 2012, p. 124). Furthermore, during this Bible study a 'religious space' became contemporaneously a 'development space'. As White and Tiongco argued 
The fundamental point here is that theology and development are together. Our basic beliefs and attitudes are not split up into boxes with different labels. We cannot separate out the 'religious bits' from the others. Both our ideas of development of our religion say something about the way the world is, and should be [emphasis in original]. (White \& Tiongco, 1997, p. 2)

It is this complete inseparability that can be difficult to understand in a dualistic western development framework, and one that needs to be understood contextually.

\section{Ruptures and tensions}

Some participants demonstrated resistance to these discourses of expertise and power, identified above, and struggled with the tensions they saw in their lives. Not all participants felt 'called' to Bangladesh. Joy and Ben, both from the States, said that they didn't really have a sense of God calling them to Bangladesh but for both of them it was a more 'pragmatic' decision. For Christina, also from the States, there was a sense of 'adventure' (2011, Christina interview, 19 Dec.).

There was some acknowledgement that the mission field was not exclusively 'over there' (although for all participants that is what it became). Katie said it "could be in your own backyard, at school, at work" but nonetheless she was called to a 'third world country'. In contrast because of Joy's prior childhood experience in Asia, for her the decision to live in Bangladesh was presented as a practical decision. Joy argued that

it wasn't about going to a far away field. But just going home to Asia, and that's how it felt in the beginning. That the first nine months are just normal, mosquitos and rice and ... hot weather and ... it was very, very normal (2011, Joy interview, 29 Nov.).

I feel some sympathy with Joy's perspective as I too, having grown up in South Asia, feel like Bangladesh is familiar. Joy went on to say that

if missionary is someone who has a heart to share the gospel with people who have not heard then yes, I am a missionary. ... Before a missionary used to be someone who goes far away from their home and comfort zone .... we're not really doing that (2011, Joy interview, 29 Nov.).

Despite this refutation she still recognised that there was a 'going there' aspect in missionary activity. While she was not, in her own words, going 'over there', she still went to a culture that was not her own, and this she called being a 'worker' (2011, Joy interview, 29 Nov.). However, her anxiety about her presence in 
Bangladesh as a western missionary demonstrated an acknowledgment that she was implicated in 'going over there' and 'saving needy Others'.

Within Joy's sentiments I heard small elements of recognition of complicity in the colonial continuities apparent in going 'over there'. Joy, and other participants were aware of the colonial heritage of mission. For her and others it was important to distance themselves from colonial mission. Joy's reflections led her to detach herself from the word missionary ("you know ... I hardly use that word anymore", 2011, Joy interview, 29 Nov.), it also led her to attempt to be selfsupporting (to not rely on church donations from her home country). In her relationships with people in Bangladesh she repeatedly expressed anxiety about how money and power changed missionaries' relationships and how missionaries worked.

Reflecting on her relationships in Bangladesh, she acknowledged that that some of the young people with whom she and her husband worked told them that all the western missionaries should go home because of the trouble they bring

they [the Bangladeshi young people] value their friendships ... they also think that everyone [missionaries] should go home. Joy also said [she and her husband] feel like this. They also feel that people should stop sending money. ... [Joy] said that on the one hand the boys tell them to stay but on the other they can see that they bring trouble by staying (2011, reflective journal, 21 Nov.).

Joy and her husband reflected on this and struggled with it but at the same time had decided to stay in Bangladesh, not because they felt 'called' there but because it was where they wanted to live.

There were problems with these responses. Like participants in Heron's (2007) study Joy tried to contain her queries of the whole missionary enterprise. Joy and her husband raised questions of power and their participation in mission many times in conversation. Their questioning whether to remain with a missionary organisation seemed to be a way to try and avoid the associations with power. I reflected in my journal

because [Joy's husband] has a business visa and a job in Bangladesh [they hope to avoid these connotations of power]. I don't know that this is totally true but I think the way they describe their wish to live in Bangladesh, their lack of 'calling' all do have a significant impact (2011, reflective journal, 21 Nov.). 
Although they raised questions and held doubts Joy and her husband still chose to stay. Heron (2007) writes that in her study some development workers were clearly told by Southern Africans ${ }^{75}$ that they were unwanted in the development spaces and organisations for whom they worked, nonetheless these participants found reasons to ignore those clear messages. She writes

African people reject us, but still we stay, and our ability to disregard or reinterpret what is being said unavoidably diminishes the subjectivity of those who dare to speak out (Heron, 2007, p. 87).

Heron argues that this ability to ignore the wishes of local people demonstrated how racism was an 'organising theme' for development workers in her study (Heron, 2007, p. 88). Rieger argued for the possibility of a postcolonial mission involving a 'radical reversal' whereby missionaries would "give up control ... commit things to God, and (as a result) leave things in the hands of those to which the mission is directed", while this is acknowledged as extremely difficult he says

as we learn to leave things in the hand of others, we learn anew what it means to leave things in the hands of God as well. In other words, as a reversal of power takes place, a reversal of authority happens as well (Rieger, 2004, p. 220).

When participants questioned the nature of 'over there', or when they acknowledged the colonial heritage of mission and attempted to move away from it (often initially by rejecting the word 'missionary'), as illustrated by Joy above, they began to recognise how they were situated in discourses of colonialism. This recognition may open potential for 'spaces of hope' (Cook, 2007, p. 80) as a significant step in building a more self-reflective practice among Christian missionaries in Bangladesh.

However participants' rejection of the word missionary was also connected with the specific context of Bangladesh. As discussed in chapter four, participants' missionary occupations had been reshaped by governmental regulations and the specific cultural and religious contexts which I discuss further in the next chapter.

\footnotetext{
${ }^{75}$ Heron's (2007) study was conducted across several southern African countries. For reasons of confidentiality she does not specify in which countries participants worked but refers throughout to Southern Africa
} 


\section{Conclusion}

In this chapter I discussed several significant aspects of participants' stories. I identified 'calling' as an important reason given by participants for their presence in Bangladesh. I noted that 'sharing' played a significant role in participants' activities. I also argued that participants' stories of calling, sharing, and helping were connected to narratives of sacrifice and benevolence. I connected my analysis to research on development workers. I recognised that participants demonstrated some resistance to or acknowledgement of discourses of power, westernisation, and colonisation. I also provided an example of one missiondevelopment activity in which spirituality was centred.

This analysis shows how participants' occupied spaces between mission and development. They responded to Christian narratives of calling within historic contexts of colonial expansion. Their activities depended on their spiritual (mission) subjectivities, and also on their western subjectivities. These participants' stories of mission and development in Bangladesh illustrate aspects of the mission-development nexus. 


\section{Chapter six: Reflections and conclusion}

\section{Introduction}

In this final chapter I first summarise my research thus far. I then reflect on missionaries' stories about 'calling' and 'sharing', and consider how the specific context shaped missionaries' activities in Bangladesh. I then turn the focus onto myself as researcher reflecting on spirituality as a key dimension of my positionality. Finally, I draw these threads together to reflect on the missiondevelopment nexus, and spirituality in research and in development. I conclude by suggesting some areas for further research.

\section{Summary of research}

I introduced this thesis with an overview of my intention and aims. I included a brief description of the context of Bangladesh and of my research approaches. I described my intention to write myself in to this research in order to supplement my analysis of participants' stories. I sought to respond to three questions. I asked about the stories missionaries in Bangladesh told about their motivations, aims, and practices. I questioned how aspects of belief/faith/religion in these missionaries' stories and actions inform understandings about the missiondevelopment nexus. Finally I asked how belief/faith/religion could be better acknowledged in development and in research.

In chapter two I introduced religion and development research and argued that little has been written about Christian missionaries. I noted various historic approaches to religion in development. I also noted that a wider engagement with religion, particularly the 'transcendental' nature of faith/belief, has been advocated (Deneulin \& Bano, 2009; Deneulin \& Rakodi, 2011; Ter Haar, 2011; Ver Beek, 2000). Additionally, I argued that religion and development research has little regarded the significance of faith/belief/religion for people who do development, be they development workers or 'recipients'. I noted that faith/belief/religion was also neglected in research on development workers (Cook, 2007; Crewe \& Harrison, 1998; Eriksson Baaz, 2005; Heron, 2007).

In chapter three I identified and described my research approaches. I discussed epistemological influences, the activities I undertook, and the ethical 
considerations I encountered. My approach highlighted for me the complexities in the mission-development nexus, as I lived with participants and experienced how their lives were not easily divided into 'development' or 'mission'. My approach also emphasised the difficulty of writing about faith/belief in a secular academic institution.

In chapter four I contextualised this research within Christian mission paradigms and mission history in Bangladesh. This context illustrated how missionary organisations in Bangladesh, and participants in this study, adapted to changing environments. This context also demonstrated how the mission-development nexus was blurred in Bangladesh as a result of these shifts.

In chapter five I focused on participants' stories. I introduced participants' background and work. I then analysed why they were in Bangladesh. Almost all participants were driven by a sense of call from God. I discussed the theological background to 'calling' and current as well as historic implications for missionary practice. I then discussed what participants did in Bangladesh. Their activities were purposed around 'sharing', which was theological and practical. Participants' sharing also connected to discourses of power, [neo]colonialism, and development. I compared these stories to analyses of development workers and identified similarities between development workers and participants.

Below I further discuss how the specific context of participants' work and activities inform the mission-development nexus. First I consider how participants' stories contribute to understanding connections between mission and development. Second I argue that place was influential in shaping the missiondevelopment nexus in Bangladesh.

\section{The mission-development nexus}

\section{Participants' stories and the Mission-development nexus}

Participants' stories demonstrated current and historic connections between mission and development. In chapter five I considered the mission-development nexus through the lives of people who 'do' mission and development. Participants' stories additionally demonstrate similarities with development worker stories as analysed by Cook (2007), Eriksson Baaz (2005), Heron (2007), and Kothari (2006b), among others. 
Similarities between development workers and missionaries were seen in the reasons why participants' became 'missionaries'. As identified in chapter five, many participants described being 'called' to a place 'over there'. In this they [re]constructed relationships with and produced understandings of an Other, and of the 'third world' as a place of need. Additional similarities were exemplified in the way missionaries 'shared' or 'helped' (Cook, 2007; Crewe \& Harrison, 1998; Heron, 2007; Kothari, 2005, 2006b). Participants' stories of altruism and sacrifice also reflected, and I think, historically constructed, similar development worker discourses (Fechter, 2012a, 2012b). Likewise, similarities were seen in references to modernisation paradigms of development (Crewe \& Harrison, 1998; Kothari, 2005; Parpart, 1995), or when participants reproduced narratives of spiritual or technical expertise (Crewe \& Harrison, 1998; Kothari, 2005, 2006b). Participants held a strong sense of belief/faith (in God and/or in 'western' ideologies). Belief was a significant motivator in, and shaped practices of, 'development' and 'mission' among participants.

I think participants' stories demonstrated how these actors shaped 'development' in similar ways to development workers. Their stories also show how historic ties between 'mission' and 'development' were experienced by participants' in Bangladesh, further illustrating the always-already nature of the missiondevelopment nexus (Fountain, 2012, p. 152). Finally I think these stories show that the mission-development nexus is shaped through the lives of (mostly) westerners who participate in development as missionaries and as secular development workers.

\section{Place matters}

In this research it was also evident that place was significant in directing how mission and development interacted in Bangladesh. As discussed in chapter four, participants' involvement in development work was often, at least partially, structured by the need to have an NGO visa and by government regulation.

In Bangladesh government constraints directed the ways in which participants took part in various mission-development activities. In particular, government regulation formalised participants' engagement in development through NGO registration. This formalised control produced changes in the ways participants viewed their missionary role. Some participants identified very strongly as development workers, social workers, engineers, or teachers. Other participants 
identified strongly as not development workers and their visa status reflected this identification; these participants avoided registration with NGOs by engaging in business concerns in Bangladesh. Only a few participants identified strongly and clearly as 'missionaries', however, NGO work was still noted as significant in their missionary role. In this research the context of Bangladesh shaped participants' involvement in development and in mission.

For some participants changing missionary theology also prompted engagement in development in Bangladesh, particularly 'holistic mission' theology. However, as noted in chapter two and chapter four, Christianity has, since its inception, participated in what might be called 'development' and in 'mission'. Consequently, I think participants' involvement in development NGO work in Bangladesh is a different manifestation of some of the ways in which mission and development have always interacted.

\section{Reflections on the research process}

In Bangladesh I felt constructed in faith relationships. ${ }^{76}$ । identified and was identified as a Christian woman, ${ }^{77}$ consequently I appeared to be a church insider. I did not feel entirely in control of that process. Often I felt that I allowed myself too straightforwardly to be seen as Pentecostal Christian or even simply comfortable in a Pentecostal church environment. I felt this was deceitful to the people around me and to my own experience of faith.

I was raised Christian, my parents were New Zealand Baptist missionaries and my family attended a Baptist church, and I grew up a practicing and believing Christian. In multiple ways being a Christian, belief in God and the praxis of faith was a significant part of my identity. This remains the case, however my experience and understanding of faith has changed significantly over time. I find the structures, beliefs, and practices of many churches hard to reconcile with my current faith praxis. $^{78}$

\footnotetext{
${ }^{76}$ During this research I found spirituality, race, and gender to be significant intersecting subject positions. Moreover, I had extensive conversations with participants about how it felt to be a white woman in Bangladesh, which contributed to my understanding of their stories. However, to emphasise the significance of spirituality throughout the research, and for the purposes of clarity, I have chosen to privilege spirituality and only discuss my positionality in this subject position. Although I will continue to supplement my discussion with reference to gender and race.

77 I was also positioned by myself and others as a researcher. For more on how researchers are positioned in the field see Cupples (2002).

${ }^{78}$ Reflecting on my spiritual history during my research led me to also consider my physical history in Bangladesh. Eriksson Baaz writes that fieldwork "made me reread the place of my childhood as a
} 
I include my church background because my experience of church and of Christianity on fieldwork was often similar to one which I had deliberately chosen to leave. I was unwilling to criticise my friends' church choices and also unwilling to isolate myself from an important part of their lives so I attended religious activities willingly and respectfully. I struggled between respect for other belief/faith practices, a wish for social assimilation as part of the research process, and a desire to be honest about what I really believe. The ethics of my honesty was troubling, and, I found, accentuated by living with, and participating extensively in the religious activities of, my hosts and research participants, as detailed in chapter three. ${ }^{79}$

I also include this personal information about faith because I approached this research with an understanding that for people for whom spirituality is significant, it is holistically part of life, not an aspect or appendage that acts on other more important events and attributes. I wrote while in Bangladesh

The anecdotal evidence, and what I see and hear, and my own experience is that when you believe in God, when you follow a religion, to some extent it will always be part of your life, as long as you continue to believe. This is not just that you spend one day a week at a religious institution for a couple of hours (church and mosque). You don't. You have church, and you have Bible studies, and the call to prayer goes five times a day, and you have youth group, and you say grace at meal times and you pray with your children when they go to bed, and you talk to your neighbours about what you believe, or why you do things differently, and you give money to beggars, and you read the Bible, and books about faith, and you are living in Bangladesh (because of your faith) ... and all these things add up to make me think how on earth is it possible to think that you can have a separation between church and life. It is not something that is tacked on to the end of an activity or before a meeting. It is a deep thread, a central piece (2011, pers. comm., 20 Nov.).

As noted by others, for many people faith is inseparable from life (Deneulin \& Bano, 2009, p. 119).

post-colonial site, with all that entails of racism, power inequalities, ambivalent identification, mimicry and hybridity" (2005, p. ix). I felt that the intersection between race and spirituality was particularly significant in research with 'missionaries' who were both 'raced' and 'religious'. I especially considered this intersection through my own experiences in Bangladesh. My reflections also led me to discuss experiences of being a 'bideshi' with participants.

79 My physical experiences living with participants also prompted reflection on our shared experiences of gender and religion in Bangladesh. Most of the women I interviewed spoke in depth about being a white/bideshi woman in Bangladesh. Although never clearly articulated I think my discussions with participants about how it felt to be a white woman in Bangladesh often subtly reflected discourses of a dangerous, sexualised (and specifically racialised) male other (see Cook, 2007, p. 48; Heron, 2007, p. 36). 
I also acknowledge that my spirituality influenced me in choosing this topic, and in my preconceptions about it, namely that Christians should be concerned with action on poverty, inequality, and social and political injustices. In this conviction I am influenced by writers such as Shane Claiborne (2006), and Dave Andrews (1999), among others. As a result I thought that 'missionaries' should be working in 'development' in some capacity. In retrospect this was a limited understanding of the interaction between mission and development. I include it here because my spiritual beliefs influenced my pre-fieldwork assumptions about my 'results'.

Furthermore, I include a discussion on spirituality because, as noted in chapter three, religious activities played a significant and sometimes difficult role in my research. To not participate in these activities or to disregard their significance would ignore the public and private expression of the faith that was so important to the people with whom I spoke.

Finally I include my spiritual positionality because spirituality and religious beliefs (or the absence of them) has not been widely discussed in research methodology or in development studies. Eleanor Sanderson writes that the "hierarchical binaries which have resulted in the under-representation of emotional knowledge within research $\ldots$ are also reflected in the under-representation of spiritual knowledge" (Sanderson, 2012, p. 122; see also Mandrell, 2009).

It was difficult for me to both validate and describe what I felt to be my complicated status of believer and insider and (secular) academic outsider. An position further tangled by personal relationships held with research participants and by social religious activities collectively undertaken. It was a relief to me when I read that "emotional engagement and spiritual engagement with research participants are closely intertwined" (Sanderson, 2012, p. 123) as this was my experience.

When I tried to write about how belief in God 'complicates' research I found myself boxing belief/faith into the exact spaces that I critiqued. Ingie Hovland wrote about the difficulty she experienced incorporating God in her research, she said

whenever I tried to bring God into the anthropological text as an undecidable possibility rather than a decided absence, I was not able to find the words to write. And whenever I tried to cross the line back to myself - not just my presence ... but my beliefs and 
the way they were influenced ... it felt like I was committing sacrilege within the academic system (Hovland, 2003, p. 8).

In this thesis I separated spaces where I wrote about faith (my own and others'), while I simultaneously advocated for the inclusion of faith/belief in development studies. As Deneulin and Bano (2009) argue, it is not enough to include belief without genuinely responding to the transcendental nature of this belief. In this research I found belief in God very difficult to respond to. The nature of academic research is so thoroughly secular that including the sacred was challenging (Fountain, 2011; Hovland, 2008; Milbank, Pickstock, \& Ward, 1999; Sanderson, 2012; Skeaff, 2011).

I struggled to critique 'the academy' approach to spirituality (Shahjahan, 2005; Shahjahan \& Haverkos, 2011). Firstly because I noted that the 'western' academic institutions were founded in Christian traditions, in values and institutional structure (Shahjahan, 2005, p. 705, n.5). Additionally, Christian influence in the academy produced hegemonic discourses which have overridden other spiritual traditions (Shahjahan \& Haverkos, 2011). I was aware of the way Christianity imposed and continues to impose colonial control over other religions, the people who practice them, and the spaces in which they are practiced. Therefore emphasising my own specifically Christian spirituality in this context may have contributed to these colonial and paternalistic outcomes.

Where spirituality in research has been acknowledged it has "too often ... only been deemed to be significant in relation to the Other, either the Other 'Elsewhere' or the Other as 'Minority'” (Maddrell, 2009, p. 675; see also Hovland, 2003). Riyad Shahjahan argued that these approaches to spirituality are an aspect of the colonisation of knowledge

western knowledge systems within the academy, as derivatives of colonialism ... can strip off the spirituality of people like me, so that our spiritual worldviews, and our histories, are 'disfigured and destroyed' (Shahjahan, 2005, p. 694).

I raised my own spirituality, and the beliefs of participants in this study, in order to demonstrate the absences in the western academic tradition as they affect people for whom spirituality is significant. However, I acknowledge that I raised spirituality through a powerful group. 
Secondly, recognising the hidden heritage of Christianity within the academic tradition, I also identified the current secular dominance of this tradition. The "'hidden curriculum' in higher education is so secular ... that it 'serves to supress religion in all its forms'” (citing Seljak, 2003, Shahjahan, 2005, p. 705, n.5). I found during this research that the academic tools available for research, analysis, and writing concerning spirituality are limited by the, often unacknowledged, taboo regarding spirituality. Like Sanderson I found my

ability to negotiate and articulate the spiritual aspects of emotional engagement with research participants severely limited by the lack of research addressing the dynamics of spirituality in the disciplines of geography and development studies (Sanderson, 2012, p. 122).

Recognising the secular tradition, the Christian heritage, and the colonising discourses evident in research methodologies (see for example L. T. Smith, 2012), I nonetheless wanted to draw attention to absence of literature acknowledging spirituality, particularly within the discipline of development studies.

Riyad Shahjahan asked "how would centering spirituality transform our ways of knowing and in turn lead toward very different insights, relationships and methods" (2005, p. 687). He referred primarily to education/pedagogy research where "there is scant literature that discusses the question of integrating spirituality into knowledge production in higher education, particularly in the context of research inquiry" (Shahjahan, 2005, p. 687). Yorgason and Dora add that "we are doing more than neglecting important epiphenomena when we fail to account for religion and spirituality; we may also be omitting fundamental features of social space" (Yorgason \& Dora, 2009, p. 635).

There are a number of ways that spirituality may be incorporated into future research. ${ }^{80}$ Spirituality and belief structures may be considered a personal help for the researcher. Spirituality and formalised religious structures may provide a connecting location for researchers, physically, mentally, and emotionally. Shared spiritual conviction may also provide added understanding to research processes. Finally (and possibly the least considered and most complicated) spirituality may

\footnotetext{
${ }^{80}$ I refer primarily to the ways in which it may be already incorporated for researchers who consider themselves as in some way 'spiritual'. For others religion or spirituality may be approached entirely differently in research.
} 
create a connection between researchers and participants which is through God and with God (Sanderson, 2012).

I do not think that spiritual positionality should always be acknowledged, but it may be deeply significant for some researchers and some of those researched, and it is frequently absent from the methodology of research. Feminist researchers have advocated successfully for the recognition of the embodied researcher, I identify an 'enspiritualed' researcher. As Shahjahan argued, "our challenge lies in developing methodologies that are aligned with our spirituality and our lived experiences" (2005, p. 697).

My research experience challenged me to consider methodologies which encompassed spirituality; however, I feel that I largely failed to do so. I experienced what Hovland described

It is beginning to dawn on me that any divisions in the anthropology of religion cannot simply be kept at the abstract level of the nature of knowledge within the field. The divisions supplant themselves downwards to the researcher and present themselves as practical negotiations over identity ... leading on to immediate methodological problems (Hovland, 2003, p. 3)

I felt restricted by the academic environment in which I conducted this research, and I realised too late the significance of research which encompassed spirituality. Although I participated in 'spiritual activities' while researching, I was unaware of how these activities and beliefs could answer questions about the production of knowledge or ways of knowing. My research explicitly concerned participants' spiritual worldviews and yet my ability to connect with these ways of knowing and then reinterpret them back into 'secular academic' language was limited. As Shahjahan argues, 'we need to build new tools' in order to more fully engage with spirituality (Shahjahan, 2005, p. 697).

\section{Trying to bring things back together: Centring spirituality in development and research}

Belief in God may 'complicate' and 'simplify' engagement in development for participants (Heron, 2007). Belief in God also complicated and simplified my engagement in this research. As noted above, I felt that my research failed on some levels to connect with participants' spiritual beliefs. My analysis of 
spirituality in research was a partial attempt to re-acknowledge the centrality of spirituality in the lives of the people with whom I spoke.

I believe this re-acknowledgement is necessary if I am to attempt to respond to the questions posed in my introduction. That is; what can belief/faith/religion in missionaries stories tell us about the development-mission nexus; and, how do we talk about and understand belief/faith/religion in development and in research?

It seems clear to me that future engagement with belief/faith by researchers and development practitioners or institutions must contain a genuine willingness and openness to engage with peoples' belief in God. As Jill De Temple said

Only when we understand development as a process that remains tangled up with people's cosmologies, many of them religious, can we accurately describe and analyze a development which reflects local and global worldviews or the movement that brings them together. God may not need a passport, but until we can see that people with passports often presume that they are working and traveling for God, we will not have a complete picture of religion or development, their effects or their possibilities, in the contemporary world (DeTemple, 2006, p. 179).

My centring of missionary narratives attempted to bridge some of the gaps in the ways faith/belief/religion has been spoken of and written about particularly in development studies.

I situated missionary narratives within discourses of colonialism and development not in order to diminish the significance of spirituality but to demonstrate that the relationship between mission and development is 'always-already' present (Fountain, 2012, p. 152). I drew attention to the ways in which missionary stories about 'calling' or 'sharing' have both a spiritual significance and exist in contexts of 'westernisation', colonialism, and development. Participants' practices were influenced by secular discourses and in turn may influence secular discourses in development contexts. The influence of Christianity is already seen in discourses of expertise (Crewe \& Harrison, 1998; Kothari, 2005, 2006b), the 'helping imperative' (Heron, 2007), altruism (Fechter, 2012a), and sacrifice (Fechter, 2012a, 2012b; Han, 2011; Stirrat, 2008). Consequently the spiritual is not found tidied away in a specific 'boxes' (2011, Joy interview, 29 Nov.; see also White \& Tiongco, 1997), but may be found throughout secular discourse. 
Finally I want to consider how a genuine acknowledgment of belief in God, or the transcendental may complicate engagement between secular and religious actors. I tentatively follow Sanderson (2012) who suggests that as a Christian, she researched through and with God and this complicated how she wrote about her research ${ }^{81}$ (see also Slater, 2004). I suggest that this analysis could be extended beyond the research process. Engaging with spirituality in 'development' may require that for some people, on some occasions, engagement occurs through and with God.

For the religiously motivated actor, the relationship between 'us', the development worker, and 'them', the beneficiary of development work, may be altered and extended by belief in God. Participants' constructed a spiritual and bourgeois subjectivity through and with relationships to a constructed 'other' and through and with relationship with God.

It is difficult to take into account this unknown, unquantifiable, and for some people non-existent factor. It is further difficult to acknowledge other people's belief in God, regardless of personal belief, and to realise that belief may have on-going implications in development engagement. As Bornstein argues "when we, as ethnographers, embrace the possibility of indeterminacy in ritual, we also acknowledge the realm of the sacred: that which cannot be spoken" (Bornstein, 2006, p. 100).

Secular anthropology, ethnography, and development studies deliberately created spaces where only secular understanding could be presented (Hovland, 2003; Shahjahan \& Haverkos, 2011). The challenge may be to accept the limits of our understanding, and yet to try and broaden the ways in which we can write faith/belief in to our research.

There is a need to understand more about how faith/belief/religion is significant in peoples' lives. I believe that in order to do this without quantifying, or 'boxing', how faith functions there needs to be more ethnographic research which allows for the possibility of the sacred within secular research practices. To allow, as Bornstein (2006), Sanderson (2012), and others discuss, for the unquantifiable and incomprehensible spaces of belief. Allowing for these spaces of uncertainty

\footnotetext{
${ }^{81}$ She writes "This embodiment relates not only to Amila and myself, but also to God: in being with each other, Amila and I were also being with God." (Sanderson, 2012, p. 125)
} 
may be necessary for research about spirituality in methodology and writing-in, and in wider spaces of development practice.

Detailed research with groups of spiritually motivated actors may demonstrate how faith/belief/religion is influential in different ways and across different contexts. Such research may also show how engagement by secular actors with religious actors could be adapted to suit a variety of contexts. Research could also open areas for new engagement to occur with previously isolated groups. ${ }^{82}$ As Cassandra Balchin notes,

having suddenly discovered [religion], [secular NGOs] lack the analytical tools essential for an informed engagement that can sufficiently account for the diversities of political positions among religious groups and religious authorities (2011, p. 17; see also Rakodi, 2012b)

Further research with faith-based groups and faith-motivated individuals has the potential to provide insight for relationships with faith-based groups and individuals, and the tools to better engage with these actors.

As concerns Christian missionaries particularly, there continues to be a need for improved understanding of what Christian mission involves. I believe this research should come from external groups and individuals, but I also think that internal mission reflection and analysis would be insightful. I think that internal missionary reflection on a postcolonial practice could be beneficial for Christian missionaries. Rieger (2004) has already suggested some ways of practicing postcolonial mission, much of which concerns responding locally to mission concerns instead of going 'over there'. More work could build on this beginning.

Most significant should be considering what mission means in collaboration with theologians and missionaries from the Global South. As Mrinalini Sebastian writes

any radical discussion of mission today ... needs to incorporate a way of critically engaging with the continued difference between countries of the West that once sent missionaries, and the countries that the missionaries evangelized (Sebastian, 2004, p. 76)

\footnotetext{
${ }^{82}$ For example, Balchin (2007) notes that development engagement with Muslims invariably occurs with 'moderate groups', there is potential for research to demonstrate how engagement can occur beyond this limited category.
} 
Christian missionary practice has changed, and continues to change. More research into what 'mission' means could be highly beneficial, particularly for mission groups who are experiencing these changes (such as in Bangladesh where mission groups are explicitly becoming involved in NGO styled 'development'). Lessons could also be learned from missionary practice from the Global South. More research on these changes could also be highly beneficial for recipient groups who may be responding in various ways to external mission activities.

There is room for more research to be conducted on how belief in God complicates and simplifies engagement in 'development' for all actors involved. 


\section{References}

Ahmed, S. (2004). Bangladesh: Past and present. New Delhi, India: A.P.H. Publishing Corporation.

Alkire, S. (2006). Religion and development. In D. A. Clark (Ed.), Elgar companion to Development Studies (pp. 502-510). UK: Edward Elgar Publishing Limited.

Andrews, D. (1999). Christi-Anarchy: Discovering a Radical Spirituality of Compassion. Oxford: Lion Pub.

Andrews, M., Day Sclater, S., Squire, C., \& Tamboukou, M. (2004). Narrative research. In C. Seale, G. Gobo, J. F. Gubrium \& D. Silverman (Eds.), Qualitative research practice (pp. 109-124). Thousand Oaks, California: Sage.

Anne (2011, 28 November). [Interview].

Apthorpe, R. (2012). Effective aid: the poetics of some aid workers' angles on how humanitarian aid 'works'. Third World Quarterly, 33(8), 1545-1559. doi: 10.1080/01436597.2012.698141

Asad, T. (2003). Formations of the secular: Christianity, Islam, modernity. Stanford, Calif: Stanford University Press.

Bakke, O. M. (2010). Implicit racism among Norwegian missionaries: a case study on the description of Africans by Olav Guttorm Myklebust. Mission Studies, 27(1), 39-55.

Balchin, C. (2007). The F-word and the S-word - too much of one and not enough of the other. Development in Practice, 17(4-5), 532-538. doi: $10.1080 / 09614520701469500$

Balchin, C. (2011). Religion and development: A practitioner's perspective on instrumentalisation. IDS Bulletin, 42(1), 15-20.

Bangladesh Rehabilitation Assistance Committee. (n.d.). Bangladesh Rehabilitation Assistance Committee (BRAC) Retrieved 22 April, 2012, from http://www.brac.net/

Baxter, C., \& Rahman, S. (2003). Historical dictionary of Bangladesh (3rd ed.). Oxford: Oxford Publicity Partnership.

Bebbington, D. (1989). Evangelicalism in modern Britain. London: Unwin Hyman. 
Belshaw, D., Calderisi, R., \& Sugden, C. (2001). Faith and development: Partnership between the World Bank and the churches of Africa. USA: World Bank \& Regnum Books International.

Ben (2011, 30 November). [Interview].

Benedetti, C. (2006). Islamic and Christian inspired relief NGOs: between tactical collaboration and strategic diffidence? Journal of International Development, 18(6), 849-859. doi: 10.1002/jid.1318

Berger, J. (2003). Religious nongovernmental organisations: An exploratory analysis. Voluntas, 14(1), 15-39.

Bevans, S., \& Schroeder, R. (2004). Constants in context: A theology of mission for today. MaryKnoll, New York: Orbis books.

Blattman, C. (n.d.). Chris Blattman: International development, politics, economics, and policy, from http://chrisblattman.com/

Bonk, J. (2006). Missions and money (Revised and Expanded ed.). Maryknoll, New York: Orbis Books.

Bonk, J. (2007). Following Jesus in contexts of power and violence. Evangelical Review of Theology, 31(4), 342-357.

Bornstein, E. (2005). The spirit of development. Stanford: Stanford University Press.

Bornstein, E. (2006). Rituals without final acts: Prayer and success in World Vision Zimbabwe's humanitarian work. In M. E. Engelke \& M. Tomlinson (Eds.), The limits of meaning: Case studies in the Anthropology of Christianity (pp. 85-104). New York: Berghahn Books.

Bosch, D. J. (1991). Transforming mission: Paradigm shifts in the theology of mission. New York: Orbis Books.

Bradbury, S. (2012). The Micah mandate: An evangelical view. In M. Clarke (Ed.), Mission and development: God's work or dood works? (pp. 103121). New York: Continuum.

Bradley, T. (2005). Does compassion bring results? A critical perspective on faith and development. Culture and Religion, 6(3), 337-351. doi: $10.1080 / 01438300500460401$

Bradley, T. (2009). A call for clarification and critical analysis of the work of FBDOs. Progress in Development Studies, 9(2), 101-114. doi: $10.1177 / 146499340800900202$ 
Brigg, M. (2009). The developer's self: A non-deterministic foucauldian frame. Third World Quarterly, 30(8), 1411-1426.

Brockington, D., \& Sullivan, S. (2003). Qualitative research. In R. Scheyvens \& D. Storey (Eds.), Development fieldwork: A practical guide (pp. 57-74). Cornwall: Sage Publications.

Buijs, G. J. (2004). Religion and development. In O. Salemink, A. Van Harskamp \& A. K. Giri (Eds.), The development of religion/the religion of development (pp. 101-108). Delft: Eburon.

Buzzanell, P. M., \& Harter, L. M. (2006). (De)centering and (re)envisioning the secular hegemony of organizational communication theory and research. Communication Studies, 57(1), 1-3. doi: 10.1080/10510970500481797

Byar Bowh Si, O. (2008). Mission as transformation: An exploration of he relationship between mission and development. International Review of Mission, 97(384/385), 91-102.

Cain, K., Postlewait, H., \& Thomson, A. (2005). Emergency sex (and other desperate measures). London: Ebury Press.

Canadian International Development Agency. (1995). Christian NGOs and CIDA: Guiding Principles, Understandings and Affirmations Retrieved 12 July, 2012, from http://www.ccrda.org/files/54/files/CIDA-NGO Paper Guiding Principles, Understandings \& Affirmations.doc?bcsi-ace4aa6c9a5b57a183=1F16A41200000003P+9NXzHVNGgMbmszin1RY47 hCHwcBgAAAwAAAOQBXQAQDgAAAAAAAG8yBAA=

Cannella, G. S., \& Lincoln, Y. S. (2011). Ethics, research regulations and critical social science. In N. K. Denzin \& Y. S. Lincoln (Eds.), The Sage handbook of qualitative research (4 ed., pp. 81-90). USA: Sage Publications.

Carr, E. R. (2010). The place of stories in development: Creating spaces for participation through narrative analysis. Development in Practice, 20(2), 219-226.

Chako, E. (2004). Positionality and praxis: Fieldwork experiences in rural India. Singapore Journal of Tropical Geography, 25(1), 51-63.

Chambers, R. (1997). Editorial: Responsible well-being-a personal agenda for development. World Development, 25(11), 1743-1754. doi: 10.1016/s0305-750x(97)10001-8

Chambers, R. (2005). Ideas for development. Sterling, VA: Earthscan.

Christina (2011, 19 December). [Interview]. 
Claiborne, S. (2006). The irresistible revolution: Living as an ordinary radical. Michigan: Zondervan.

Clark, D. J. (2004). The production of a contemporary famine image: The image economy, indigenous photographers and the case of Mekanic Philipos. Journal of International Development, 16(5), 693-704. doi: 10.1002/jid.1121

Clarke, G. (2006). Faith matters: Faith-based organisations, civil society and international development. Journal of International Development, 18, 835848 .

Clarke, G. (2007). Agents of transformation? Donors, faith-based organisations and international development. Third World Quarterly, 28(1), 77-96.

Clarke, G. (2008). Faith-based organizations and international development: An overview. In G. Clarke \& M. Jennings (Eds.), Development, civil society and faith-based organizations: Bridging the sacred and the secular (pp. 17-45). GB: Palgrave McMillan.

Clarke, G., \& Jennings, M. (Eds.). (2008). Development, civil society and faithbased organisations: Bridging the sacred and the secular. GB: Palgrave McMillan.

Clarke, M. (2012). Introduction: Good and God-development and mission. In M. Clarke (Ed.), Mission and development: God's work or good work? (pp. 116). New York: Continuum.

Clifford, J. (1997). Routes: travel and translation in the late twentieth century. Cambridge, Mass: Harvard University Press.

Collin, M., \& Dissanayake, R. (n.d.). Aid Thoughts, from http://aidthoughts.org/

Collins English Dictionary. (n.d.). Definition of 'jama'at' Retrieved 16 March, 2012, from http://www.collinsdictionary.com/dictionary/english/jamaat?showCookiePo $\underline{\text { licy=true }}$

Comaroff, J., \& Comaroff, J. L. (1997). Of revelation and revolution: Christianity, colonialism, and consciousness in South Africa. Chicago: University of Chicago Press.

Conradie, E., M. (2005). Mission as evangelism and as development? Some perspectives from the Lord's prayer. International Review of Mission, 94(575), 557-575.

Cook, N. (2005). What to wear, what to wear?: Western women and imperialism in Gilgit, Pakistan. Qualitative Sociology, 28(4), 351-369. doi: 10.1007/s11133-005-8363-4 
Cook, N. (2006). Bazaar stories of gender, sexuality and imperial spaces in Gilgit, Northern Pakistan. ACME: An International E-Journal for Critical Geographies, 5(2), 230-257.

Cook, N. (2007). Gender, identity and imperialism: Women development workers in Pakistan. USA: Palgrave MacMillan.

Cook, N. (2008). Shifting the focus of development: Turning 'helping' into selfreflexive learning. Critical Literacy: Theories and Practices 2(1), 16-26.

Cope, M. (2002). Feminist epistemology in Geography. In P. Moss (Ed.), Feminist Geography in practice: Research and methods (pp. 43-56). Cornwall, GB: Blackwell Publishers.

Cresswell, J. (2003). Research design: Qualitative, quantitative and mixed methods approaches. USA: Sage publications.

Crewe, E., \& Fernando, P. (2006). The elephant in the room: Racism in representations, relationships and rituals. Progress in Development Studies, 6(1), 40-54. doi: 10.1191/1464993406ps126oa

Crewe, E., \& Harrison, E. (1998). Whose development? An ethnography of aid. UK: Zed Books.

Crouch, D. (2001). Spatialities and the feeling of doing. Social \& Cultural Geography, 2(1), 61-75. doi: 10.1080/14649360020028276

Cupples, J. (2002). The field as a landscape of desire: Sex and sexuality in geographical fieldwork. Area, 34(4), 382-390. doi: 10.1111/14754762.00095

Davis, K., \& Clark, B. (2011). Kisses from Katie: A story of relentless love and redemption. New York: Howard Books.

De Cordier, B. (2009). The 'humanitarian frontline', development and relief, and religion: What context, which threats and which opportunities? Third World Quarterly, 30(4), 663-684. doi: 10.1080/01436590902867086

de Kadt, E. (2009). Should God play a role in development? Journal of International Development, 21(781-786).

Debnath, M. (2011). The invisible agenda: Civilising mission or missionising civilisation. The International Journal of Human Rights, 16(3), 461-473. doi: 10.1080/13642987.2011.572550

Deneulin, S., \& Bano, M. (2009). Religion in development: Rewriting the secular script. New York: Zed Books. 
Deneulin, S., \& Rakodi, C. (2011). Revisiting religion: Development studies thirty years on. World Development, 39(1), 45-54. doi: 10.1016/j.worlddev.2010.05.007

Denzin, N. K., \& Lincoln, Y. S. (2005a). Introduction: The discipline and practice of qualitative research. In N. K. Denzin \& Y. S. Lincoln (Eds.), The Sage handbook of qualitative research (3rd ed., pp. 1-32). Thousand Oaks: Sage Publications.

Denzin, N. K., \& Lincoln, Y. S. (2005b). The Sage handbook of qualitative research. Thousand Oaks: Sage Publications.

Department for International Development. (2012). Faith partnership principles: Working together with faith groups to fight global poverty. http://www.dfid.gov.uk/: Department for International Development (DfID).

DeTemple, J. (2006). 'Haiti appeared at my church': Faith-based organizations, transnational activism, and tourism in sustainable development. Urban Anthropology and Studies of Cultural Systems and World Economic Development, 35(2/3), 155-181.

DeWalt, K. M., \& DeWalt, B. R. (2001). Participant observation: A guide for fieldworkers. Walnut Creek, CA: AltaMira Press.

Dogra, N. (2007). 'Reading NGOs visually'-Implications of visual images for NGO management. Journal of international Development, 19(2), 161-171. doi: $10.1002 /$ jid. 1307

Dowling, R. (2010). Power, subjectivity, and ethics in qualitative research. In I. Hay (Ed.), Qualitative research methods in human Geography (3rd ed., pp. 26-39). Ontario, Canada: Oxford University press.

Edgar, S. L., \& Nees, H. (1985). Toward the sunrise: The centenary history of the New Zealand Baptist Missionary Society. Auckland, N.Z: New Zealand Baptist Historical Society for the New Zealand Baptist Missionary Society.

Editorial. (1999). Editorial. Gender and Development, 7(1), 2-6.

Einagel, V. I. (2001). Telling stories, making selves. In L. Bondi, et al. (Ed.), Subjectivities, knowledges, and feminist geographies (pp. 223-235). Oxford: Roman \& Littlefield Publishers.

Elliot, E. (1987). A Chance to Die: The Life and Legacy of Amy Carmichael: Revell.

England, K. (1994). Getting personal: Reflexivity, positionality, and feminist research. The Professional Geographer, 46(1), 80-89. 
Eriksson Baaz, M. (2005). The paternalism of partnership: A postcolonial reading of identity in development aid. Malta: Zed Books.

Escobar, A. (1995). Encountering development: The making and unmaking of the Third World. Princeton, N.J: Princeton University Press.

Escobar, A. (1997). The making and unmaking of the Third World through development. In M. Rahnema \& V. Bowtree (Eds.), The post development reader (pp. pp 85-93). London: Zed Books.

Eyben, R. (2012). Fellow travellers in development. Third World Quarterly, 33(8), 1405-1421. doi: 10.1080/01436597.2012.698105

Fechter, A.-M. (2012a). 'Living well' while 'doing good'? (Missing) debates on altruism and professionalism in aid work. Third World Quarterly, 33(8), 1475-1491. doi: 10.1080/09700161.2012.698133

Fechter, A.-M. (2012b). The personal and the professional: Aid workers' relationships and values in the development process. Third World Quarterly, 33(8), 1387-1404. doi: 10.1080/01436597.2012.698104

Fonow, M. M., \& Cook, J. A. (1991). Back to the future: A look at the second wave of feminist epistemology and methodology. In M. M. Fonow \& J. A. Cook (Eds.), Beyond methodology: Feminist scholarship as lived research (pp. 1-15). Bloomington: Indiana University Press.

Fountain, P. (2011). Translating service: An ethnography of the Mennonite Central Committee. Doctor of Philosophy, The Australian National University Canberra, Unpublished Doctoral thesis.

Fountain, P. (2012). Blurring misison and development in the Mennonite Central Committee. In M. Clarke (Ed.), Mission and development: God's work or good work? (pp. 143-166). New York: Continuum.

Gauri, V., \& Galef, J. (2005). NGOs in Bangladesh: Activities, resources, and governance. World Development, 33(12), 2045-2065. doi: 10.1016/j.worlddev.2005.05.009

Gibson-Graham, J. K. (1994). 'Stuffed if I know!': Reflections on post-modern feminist social research. Gender, Place \& Culture: A Journal of Feminist Geography, 1(2), 205.

Google Maps. (2012). Bangladesh Map Retrieved 19 September, 212, from http://maps.google.co.nz/maps?hl=en\&rls=com.microsoft:en-nz:IE-

Address\&bav=on.2,or.r gc.r pw.r gf.\&biw=1920\&bih=899\&wrapid=tlif134 $802251531010 \& q=$ bangladesh + map \&um $=1 \& \mathrm{ie}=U T \mathrm{TF}-$

$8 \& \mathrm{hq}=\& \mathrm{hnear}=0 \times 30$ adaaed $80 \mathrm{e} 18 \mathrm{ba} 7: 0 \times \mathrm{f} 2 \mathrm{~d} 28 \mathrm{e} 0 \mathrm{c} 4 \mathrm{e} 1 \mathrm{fc} 6 \mathrm{~b}$, Bangladesh \&gl $=n z \& s a=X \& e i=u k 5 Z U K$ wLq7BiQfC9oC4Dw\&ved=0CB0Q8gEwAA 
Goulet, D. (1980). Development experts: The one-eyed giants. World Development, 8, 481-489.

Green, M., Mercer, C., \& Mesaki, S. (2012). Faith in forms: Civil society, evangelism and development in Tanzania. Development in Practice, 22(56), 721-734. doi: 10.1080/09614524.2012.685866

Gronemeyer, M. (1992). Helping. In W. Sachs (Ed.), The development dictionary: A guide to knowledge as power (pp. 53-69). Johannesburg: Witwatersrand University Press.

Guinness, O. (2003). The call: Finding and fulfilling the central purpose of your life. USA: Thomas Nelson.

Haggis, J., \& Schech, S. (2000). Meaning well and global good manners: Reflections on white western feminist cross-cultural praxis. Australian Feminist Studies 15(33), 387-389.

Han, J. H. J. (2011). "If you don't work, you don't eat": Evangelizing development in Africa. In J. Song (Ed.), New millennium South Korea: Neoliberal capital and transnational movements (pp. 142-158). London: Routledge.

Haque, M. S. (2002). The changing balance of power between the Government and NGOs in Bangladesh. International Political Science Review, 23(4), 411-435. doi: 10.1177/0192512102023004006

Haraway, D. (1988). Situated knowledges: The science question in feminism and the privilege of partial perspective. Feminist Studies, 14(3), 575-599.

Haynes, J. (2007). Religion and development: Conflict or cooperation? GB: Palgrave McMillan.

Hearn, J. (2002). The 'invisible' NGO: US Evangelical missions in Kenya. Journal of Religion in Africa, 32(1), 32-60.

Hedayetul Huq, A. (1999). Aspects of Christian NGO work in a Muslim society: Challenges and response in Bangladesh. South Asia, 22(Special issue), 209-220.

Herbert, D. (2003). Religion and civil society: Rethinking public religion in the contemporary world. Aldershot: Ashgate.

Heron, B. (2007). Desire for development: Whiteness, gender and the helping imperative. Ontario: Wilfred Laurier University Press.

Hoek, M., \& Thacker, J. (Eds.). (2008). Micah's challenge: The church's responsibility to the global poor. GB: Paternoster. 
Hovland, I. (2003). Careful, you might lose something: On being disciplined into the anthropology of religion. Anthropology Matters, 5(2), 1-8.

Hovland, I. (2008). Who's afraid of Religion? Tensions between 'mission' and 'development' in the Norwegian Mission Society. In M. Jennings \& G. Clarke (Eds.), Development, civil society and faith-based organisations: Bridging the gap between the sacred and the secular (pp. 171-186). Great Britain: Palgrave MacMillian.

Howell, B. M. (2007). The repugnant cultural other speaks back. Anthropological Theory, 7(4), 371-391. doi: 10.1177/1463499607083426

Humble, D. (2012). "This isn't getting easier": Valuing emotion in development research. Emotion, Space and Society, 5(2), 78-85. doi: 10.1016/j.emospa.2011.04.001

Hutnyk, J. (2004). Photogenic poverty: Souvenirs and infantilism. Journal of Visual Culture, 3(1), 77-94. doi: 10.1177/1470412904042266

International Human Development Indicators. (n.d.). Bangladesh Country Profile: Human Development Indicators Retrieved 30 April, 2012, from http://hdrstats.undp.org/en/countries/profiles/BGD.html

Interserve International. (n.d.-a). Interserve International: Following Christ amongst the peoples of Asia and the Arab World, from http://www.interserve.org/

Interserve International. (n.d.-b). Mission Today: Newer mission movements $\begin{array}{llll}\text { Retrieved } & 10 & \text { April, } & \text { 2012, }\end{array}$ http://www.interserve.org/index.php?option=com content\&view=article\&id $=79 \&$ Itemid $=53$

John (2011, 5 December). [Interview].

Jones, B., \& Petersen, M. J. (2011). Instrumental, narrow, normative? Reviewing recent work on religion and development. Third World Quarterly, 32(7), 1291-1306. doi: 10.1080/01436597.2011.596747

Joy $(2011,29$ November). [Interview].

Julie (2011, 11 November). [Interview].

Kalu, O. U. (1975). Peter Pan syndrome: Aid and selfhood of the church in Africa. Missiology, 3(1), 15-29.

Kapoor, I. (2004). Hyper-self-reflexive development? Spivak on representing the Third World 'Other'. Third World Quarterly, 25(4), 627-647. 
Kapoor, I. (2008). The Postcolonial Politics of Development. Abingdon, Oxon: Routledge.

Karim, M. (1996). NGOs in Bangladesh: Issues of legitimacy and accountability. In M. Edwards \& D. Hulme (Eds.), Beyond the Magic Bullet (pp. 132-141). West Hartford, CT: Kumarian Press.

Karns, M. P., Shaffer, T. J., \& Ghere, R. K. (2008). The Challenges of Accountability for International Nongovernmental and Civil Society Organizations. Paper presented at the Kettering Foundation Symposium on Accountability, Dayton, $\mathrm{OH}$. http://unpan1.un.org/intradoc/groups/public/documents/apcity/unpan0341 $\underline{32 . p d f}$

Kathryn (2011, 16 November). [Interview].

Katie (2011, 9 December). [Interview].

Kaufmann, G. (1997). Watching the developers: A partial ethnography. In R. D. Grillo \& R. L. Stirrat (Eds.), Discourses of development: Anthropological perspectives (pp. 107-131). New York, N.Y.: Berg.

Kearns, R. A. (2010). Seeing with clarity: Undertaking observational research. In I. Hay (Ed.), Qualitative research methods in human Geography (3rd ed., pp. 241-258). Ontario, Canada: Oxford University Press.

Kim, K. (2007). Concepts of development in the Christian traditions: a religions and development background paper. RAD Working Papers Series, Working Paper 16.

Kim, K. (2010). Mission theology of the church. International Review of Mission, 99(1), 39-55.

Kindon, S. (2012). 'Thinking-through-Complicity' with Te Iwi o Ngāti Hauiti: Towards a Critical Use of Participatory Video for Research. Doctor of Philosophy, University of Waikato, Unpublished Doctoral thesis. Retrieved from http://hdl.handle.net/10289/6286

Kothari, U. (2005). Authority and expertise: The professionalisation of international development and the ordering of dissent. Antipode, 37(3), 425-446. doi: 10.1111/j.0066-4812.2005.00505.x

Kothari, U. (2006a). An agenda for thinking about 'race' in development. Progress in Development Studies, 6(1), 9-23. doi: 10.1191/1464993406ps124oa

Kothari, U. (2006b). Spatial practices and imaginaries: Experiences of colonial officers and development professionals. Singapore Journal of Tropical Geography, 27(3), 235-253. doi: 10.1111/j.1467-9493.2006.00260.x 
Laible, J. C. (2000). A loving epistemology: What I hold critical in my life, faith and profession. International Journal of Qualitative Studies in Education, 13(6), 683-692. doi: 10.1080/09518390050211574

Lareau, A. (1996). Common problems in field work: A personal essay. In A. Lareau \& J. J. Shultz (Eds.), Journeys through Ethnography: Realistic accounts of fieldwork (pp. 195-326). Boulder, Colo: Westview Press.

Letherby, G. (2003). Feminist research in theory and practice. Philadelphia, PA: Open University Press.

Lewis, D. J. (1997). NGOs, donors, and the state in Bangladesh. The ANNALS of the American Academy of Political and Social Science, 554(1), 33-45. doi: $10.1177 / 0002716297554001003$

Lunn, J. (2009). The role of religion, spirituality and faith in development: A critical theory approach. Third World Quarterly, 30(5), 937-951. doi: $10.1080 / 01436590902959180$

Maddrell, A. (2009). A place for grief and belief: The Witness Cairn, Isle of Whithorn, Galloway, Scotland. Social \& Cultural Geography, 10(6), 675693. doi: $10.1080 / 14649360903068126$

Mahmud Ali, S. (2010). Understanding Bangladesh. India: C. Hurst \& Co.

Mallaby, S. (2004). The world's banker: A story of failed states, financial crises, and the wealth and poverty of nations. New York: Penguin Press.

Mandel, J. L. (2003). Negotiating expectations in the field: Gatekeepers, research fatigue and cultural biases. Singapore Journal of Tropical Geography, 24(2), 198-210. doi: 10.1111/1467-9493.00152

Manji, F., \& O'Coill, C. (2002). The missionary position: NGOs and development in Africa. International Affairs, 78(3), 567-583. doi: 10.1111/14682346.00267

Mansvelt, J., \& Berg, L. D. (2010). Writing qualitative geographies, constructing meaningful Geographical knowledges. In I. Hay (Ed.), Qualitative research methods in human Geography (pp. 333-355). Ontario, Canada: Oxford University Press.

Mark (2011, 28 November). [Interview].

Marshall, K., \& Keough, L. (2004). Mind, heart, and soul in the fight against poverty. Washington: The World Bank. 
McDuie-Ra, D., \& Rees, J. A. (2010). Religious actors, civil society and the development agenda: The dynamics of inclusion and exclusion. Journal of International Development, 22(1), 20-36. doi: 10.1002/jid.1537

McEwan, C. (1994). Encounters with West African women: Textual representations of difference by white women abroad. In A. Blunt \& G. Rose (Eds.), Writing women and space: Colonial and postcolonial Geographies (pp. 73-100). New York: Guilford Press.

McEwan, C. (2009). Postcolonialism and development. Abingdon, Oxon: Routledge.

McGregor, A. (2008). Religious NGOs: Opportunities for post-development? Paper presented at the Proceedings of the Aotearoa/New Zealand International Development Studies Network conference, Dunedin, NZ.

McGregor, A. (2010). Geographies of religion and development: A case study of Aceh after the tsunami. Environment and planning A, 42(3), 729-746.

McGregor, A., Skeaff, L., \& Bevan, M. (2012). Overcoming secularism? Catholic development geographies in Timor-Leste. Third World Quarterly, 33(6), 1129-1146. doi: 10.1080/01436597.2012.681497

McKinnon, K. (2007). Postdevelopment, professionalism, and the politics of participation. Annals of the Association of American Geographers, 97(4), 772-785. doi: 10.1111/j.1467-8306.2007.00582.x

Mesbahuddin, T. (2010). Religion in development. Journal of South Asian Development, 5(2), 221-241. doi: 10.1177/097317411000500202

Meyer, B., \& Pels, P. (2003). Magic and modernity: Interfaces of revelation and concealment. Stanford, California: Stanford University Press.

Michael (2011, 3 December). [Interview].

Mies, M. (1991). Women's research or feminist research? The debate surrounding feminist science and methodology. In M. M. Fonow \& J. A. Cook (Eds.), Beyond methodology: Feminist scholarship as lived research (pp. 60-84). Bloomington: Indiana University Press.

Milam, W. B. (2007). Bangladesh and the burdens of history. Current History, 106(699), 153-160.

Milbank, J., Pickstock, C., \& Ward, G. (1999). Radical orthodoxy: A new theology. New York: Routledge. 
Millennium Development Goals Monitor. (2008, 30 July 2008). Bangladesh: MDG Profile Retrieved 30 April, 2012, from http://www.mdgmonitor.org/factsheets 00.cfm?c=BGD

Moss, P. (2002). Taking on, thinking about, and doing Feminist research in Geography. In P. Moss (Ed.), Feminist Geography in practice (pp. 1-17). Malden, Massachusettes.

Mullings, B. (1999). Insider or outsider, both or neither: Some dilemmas of interviewing in a cross-cultural setting. [doi: 10.1016/S00167185(99)00025-1]. Geoforum, 30(4), 337-350.

Nairn, K. (2002). Doing feminist fieldwork about Geography fieldwork. In P. Moss (Ed.), Feminist Geography in practice (pp. 146-159). Malden, Massachusetts: Blackwell Publishers.

Narayan, D., Chambers, R., Shah, M. K., \& Petesch, P. (2000). Voices of the poor: Crying out for change. New York: Published by Oxford University Press for the World Bank.

Narayan, D., Patel, R., Shchafft, K., Rademacher, A., \& Koch-Schulte, S. (2000). Voices of the poor: Can anyone hear us? Washington, DC, USA: Oxford University Press.

Narayan, D., \& Petesch, P. L. (2001). Voices of the poor: From many lands. Washington, D.C.: Oxford University Press.

Narayan, K. (1993). How native is a 'native' anthropologist? American Anthropologist, New Series, Vol. 95(3), 671-686.

New Zealand Church Missionary Society. (n.d.). NZCMS, from http://www.nzcms.org.nz/

Non-governmental Affairs Bureau. (2012a, July 2012). Flow of Foreign Grant Fund Through NGO Affairs Bureau: At a Glance Retrieved 10 September, 2012, from http://www.ngoab.gov.bd/Files/statistics.pdf

Non-governmental Affairs Bureau. (2012b, 4 September 2012). List of NGOs in Bangladesh Retrieved 10 September, 2012, from http://www.ngoab.gov.bd/Files/NGO LIST.pdf

O'Halloran, R. (2012). Palms Australia: Missionaries, international development volunteers and beyond: Prophetic wisdom for cross-cultural engagement. In M. Clarke (Ed.), Mission and development: God's work or good works? (pp. 123-141). New York: Continuum.

Pachuau, L. (2000). Missiology in a pluralistic world: the place of mission study in theological education. International Review of Mission, 89(335), 539-555. 
Parfitt, T. (2009). Countdown to ecstasy: Development as eschatology. Third World Quarterly, 30(4), 635-648. doi: 10.1080/01436590902866823

Parpart, J. L. (1995). Deconstructing the development 'expert': Gender, development and the 'vulnerable groups'. In M. H. Marchand \& J. L. Parpart (Eds.), Feminism/Postmodernism/Development (pp. 221-243). GB: Routledge.

Ponsi, F. (1978). Contemporary concepts of mission. Missiology, 6(2), 139-153.

Porter, A. (1997). 'Cultural imperialism' and protestant missionary enterprise, 1780-1914. The Journal of Imperial and Commonwealth History, 25(3), 367-391. doi: 10.1080/03086539708583005

Preece, G. (2010). Key Topic two: Calling (Depth Article). Theology of Work Project Inc Retrieved 12 June 2012, from http://wiki.theologyofwork.org/Key Topics Articles/820 Key Topic \%232 - Calling/820.30 Key Topic \%232 - Calling (Depth Article)\# ftnref19

Punch, M. (1998). Politics and ethics in qualitative research. In N. K. Denzin \& Y. S. Lincoln (Eds.), The landscape of qualitative research: Theories and issues (pp. 156-184). Thousand Oaks, Calif: Sage Publications.

Punch, S. (2012). Hidden struggles of fieldwork: Exploring the role and use of field diaries. Emotion, Space and Society, 5(2), 86-93. doi: 10.1016/j.emospa.2010.09.005

Radley, A., \& Kennedy, M. (1997). Picturing need: Images of overseas aid and interpretations of cultural difference. Culture \& Psychology, 3(4), 435-460. doi: $10.1177 / 1354067 \times 9734001$

Rahnema, M. (1997). Towards post-development: Searching for signposts, a new language and new paradigms. In M. Rahnema \& V. Bawtree (Eds.), The post-development reader. New Jersey: Zed Books.

Rakodi, C. (2012a). A framework for analysing the links between religion and development. Development in Practice, 22(5-6), 634-650. doi: $10.1080 / 09614524.2012 .685873$

Rakodi, C. (2012b). Religion and development: Subjecting religious perceptions and organisations to scrutiny. Development in Practice, 22(5-6), 621-633. doi: $10.1080 / 09614524.2012 .686602$

Rashiduzzaman, M. (1997). The dichotomy of Islam and development: NGOs, women's development and fatawa in Bangladesh. Contemporary South Asia, 6(3), 239-246. 
Richardson, L., \& St. Pierre, E. A. (2005). Writing: A method of Inquiry. In N. K. Denzin \& Y. S. Lincoln (Eds.), The Sage handbook of qualitative research (3rd ed., pp. 959-978). Thousand Oaks: Sage Publications.

Rieger, J. (2004). Theology and mission between neocolonialism and postcolonialism. Mission Studies, 21(2), 201-227.

Rose, G. (1997). Situating knowledges: Positionality, reflexivities and other tactics. Progress in Human Geography, 21, 305-320.

Roth, S. (2012). Professionalisation trends and inequality: Experiences and practices in aid relationships. Third World Quarterly, 33(8), 1459-1474. doi: 10.1080/09700161.2012.698129

Salemink, O., Van Harskamp, A., \& Giri, A. K. (Eds.). (2004). The development of religion/religion of development. Delft: Eburon Delft.

Sanderson, E. R. (2012). Emotional engagement in the context of development and spirituality research. Emotion, Space and Society, 5(2), 122-130. doi: 10.1016/j.emospa.2010.09.006

Scheyvens, R., Nowak, B., \& Scheyvens, H. (2003). Ethical issues. In R. Scheyvens \& D. Storey (Eds.), Development fieldwork: A practical guide (pp. 139-166). Cornwall: Sage Publications.

Scroggins, D. (2002). Emma's war: An aid worker, a warlord, radical Islam and the politics of oil - A true story of love and death in the Sudan. New York: Pantheon.

Sebastian, M. (2004). Mission without history? Some ideas for decolonizing mission. International Review of Mission, 93(368), 75-96. doi: 10.1111/j.1758-6631.2004.tb00443.x

Selinger, L. (2004). The forgotten factor: The uneasy relationship between religion and development. Social Compass, 51(4), 523-543.

Serving in Mission. (n.d.). SIM, from http://www.sim.org/

Shahjahan, R. A. (2005). Spirituality in the academy: Reclaiming from the margins and evoking a transformative way of knowing the world. International Journal of Qualitative Studies in Education, 18(6), 685-711. doi: 10.1080/09518390500298188

Shahjahan, R. A., \& Haverkos, K. A. (2011). Revealing the secular fence of knowledge: Towards reimagining spiritual ways of knowing and being in the academy. In G. J. S. Dei (Ed.), Indigenous philosophies and critical education: A reader (pp. 367-385). New York: Peter Lang. 
Shotgun Shack, \& Tales from the hood. (n.d). Stuff expat aid workers like, from http://stuffexpataidworkerslike.com/

Simpson, K. (2004). 'Doing development': The gap year, volunteer-tourists and a popular practice of development. Journal of international Development, 16(5), 681-692. doi: 10.1002/jid.1120

Skeaff, L. (2011). Preparing for social action: a case study from Zambia on the relationship between religious knowledge and development. Master of Development Studies, Victoria University of Wellington, Unpublished Master's Thesis.

Slater, T. R. (2004). Encountering God: Personal reflections on 'geographer as pilgrim'. Area, 36(3), 245-253. doi: 10.1111/j.0004-0894.2004.00221.x

Smith, G. (1990). The life of William Carey; shoemaker and missionary. Boulder, Colo: Project Gutenberg.

Smith, L. T. (2012). Decolonizing methodologies: Research and indigenous peoples (2 ed.). New York: Zed Books.

Smith, S. R., \& Sosin, M. R. (2001). The varieties of faith-related agencies. Public Administration Review, 61(6), 651-670. doi: 10.1111/0033-3352.00137

Sophie (2011, 20 December). [Interview].

Spradley, J. P. (1979). The ethnographic interview. New York: Holt, Rinehart and Winston.

Stacey, J. (1988). Can there be a feminist ethnography? Women's Studies International Forum, 11(1), 21-27. doi: 10.1016/0277-5395(88)90004-0

Stanley, B. (1992). The history of the Baptist Missionary Society 1792-1992. Great Britain: T \& T Clark.

Stiles, K. (2002). International support for NGOs in Bangladesh: Some unintended consequences. World Development, 30(5), 835-846. doi: $10.1016 /$ S0305-750X(02)00012-8

Stirrat, R. L. (2000). Cultures of consultancy. Critique of Anthropology, 20(1), 31 46. doi: $10.1177 / 0308275 \times 0002000103$

Stirrat, R. L. (2008). Mercenaries, missionaries and misfits: Representations of development personnel. Critique of Anthropology, 28(4), 406-425.

Sugirtharajah, R. S. (2004). Complacencies and cul-de-sacs: Christian theologies and colonialism. In C. Keller, M. Nausner \& M. Rivera (Eds.), Postcolonial theologies: Divinity and empire (pp. 22-38). St. Louis, Mo: Chalice Press. 
Ter Haar, G. (Ed.). (2011). Religion and development: Ways of transforming the world. India: Columbia University Press.

Ter Haar, G., \& Ellis, S. (2006). The role of religion in development: Towards a new relationship between the European Union and Africa. European Journal of Development Research, 18(3), 351-376.

Thomas, N. E. (1981). Evangelism and liberation theology. Missiology, 9(4), 473484.

Tillmann-Healy, L. M. (2003). Friendship as method. Qualitative Inquiry, 9(5), 729-749. doi: $10.1177 / 1077800403254894$

Tomalin, E. (2012). Thinking about faith-based organisations in development: where have we got to and what next? Development in Practice, 22(5-6), 689-703. doi: 10.1080/09614524.2012.686600

Tripp, L. (1999). Gender and development from a Christian perspective: Experience from World Vision. Gender and Development, 7(1), 62-68.

Tvedt, T. (1998). Angels of mercy or development diplomats? NGOs and foreign aid. Oxford: James Currey Ltd. \& Africa World Press, Inc.

Tyndale, W. (2003). Idealism and practicality: The role of religion in development. Development: Religion and Development, 46(4), 22-28.

Tyndale, W. (Ed.). (2006). Visions of development. GB: Ashgate.

United Nations Children's Fund. (2012). Partnering with Religious Communities for Children. New York: UNICEF.

United Nations Populations Fund. (2009). Second United Nations inter-agency consultation on engaging faith-based organizations for the MDGs, from http://www.unfpa.org/webdav/site/global/shared/documents/publications/2 009/interagency 2009 report.pdf

Valentine, G. (1997). Tell me about ... using interviews as a research methodology. In R. Flowerdew \& D. Martin (Eds.), Methods in Human Geography: A guide for students doing research projects (pp. 110-126). Harlow: Longman.

Ver Beek, K. A. (2000). Spirituality: A development taboo. Development in Practice, 10(1), 31-43.

Walker, B. (1999). Christianity, development and women's liberation. Development, 7(1), 15-22. 
Walker, P., Hein, K., Russ, C., Bertleff, G., \& Caspersz, D. (2010). A blueprint for professionalizing humanitarian assistance. Health Affairs, 29(12), 22232230.

Walker, P., \& Russ, C. (2010). Professionalising the humanitarian sector: A scoping study. Cardiff: Enhancing Learning and Research for Humanitarian Assistance (ERLHA).

Weber, M. (1993). The sociology of religion. Boston: Beacon Press.

White, S. C. (2002). Thinking race, thinking development. Third World Quarterly, 23(3), 407-419.

White, S. C. (2012). Beyond the paradox: Religion, family and modernity in contemporary Bangladesh. Modern Asian Studies, 46(05), 1429-1458. doi: $10.1017 / S 0026749 \times 12000133$

White, S. C., \& Tiongco, R. (1997). Doing theology and development: Meeting the challenge of poverty. Tyne \& Wear: Saint Andrew Press.

Wilson, B. R. (1982). Religion in sociological perspective. Oxford: Oxford University Press.

Wilson, G. (2006). Beyond the technocrat? The professional expert in development practice. Development and Change, 37(3), 501-523. doi: 10.1111/j.0012-155X.2006.00488.x

Wolfensohn, J. D., \& Carey, G. (2001). Forward. In D. Belshaw, R. Calderisi \& C. Sugden (Eds.), Faith and development: Partnership between the World Bank and the churches of Africa. USA: World Bank \& Regnum Books International.

World Bank. (2006). Economics and Governance of Nongovernmental Organizations in Bangladesh Bangladesh Development Series Paper No: 11. http://siteresources.worldbank.org/BANGLADESHEXTN/Resources/NGOr eport Dev Series.pdf: World Bank.

Wright, C. (2006). The Mission of God: Unlocking the Bible's grand narrative. U.S.A: InterVarsity Press.

Yoder, R. A., Redekop, C. W., \& Jantzi, V. E. (2004). Development to a different drummer: Anabaptist/Mennonite experiences and perspectives. USA: Good Books.

Yorgason, E., \& Dora, V. D. (2009). Geography, religion, and emerging paradigms: Problematizing the dialogue. Social \& Cultural Geography, 10(6), 629-637. doi: 10.1080/14649360903068100 
Young, R. (2001). Postcolonialism: An historical introduction. Malden, Mass: Blackwell Publishers.

Yunus, M., \& Jolis, A. (2003). Banker to the poor: The story of the Grameen Bank. London: Aurum.

Zene, C. (2002). The Rishi of Bangladesh: A history of Christian dialogues. New York: Routledge Curzon.

Zohir, S. (2004). NGO Sector in Bangladesh: An Overview. Economic and Political Weekly, 39(36), 4109-4113. 


\title{
Appendices
}

\section{APPENDIX A: PARTICIPANT INFORMATION SHEET}

\author{
Researcher: Anna Thompson \\ Title of project: Missionary identity and development in Bangladesh
}

I am a Master's in Development Studies student at Victoria University of Wellington, New Zealand. As part of this degree I am undertaking a research project leading to a thesis. My research explores what it means to be a Christian missionary, how mission is defined and how faith shapes missionary activities in Bangladesh. This study has been granted ethics approval from the Victoria University Human Ethics Committee.

My research will involve interviewing approximately 10 people who define themselves as Christian missionaries. The interviews will be semi-structured and may include follow up interviews and informal conversations. The interviews will last between 30-60 minutes. I also hope to be a participant observer over my research period and spend time interacting with research participants. Participant observation is a research method that requires researchers to participate in the lives of the people they are researching with. By participating with interviewees in social and religious activities I hope to gain a better understanding of the meanings behind our discussion. This will include attending church services, Bible studies, prayer meetings, and formal meetings (where permitted and relevant). It will also include casual conversations, eating together and socialising with participants while I live in your homes. I may also include images and photos where relevant. Participants who do not wish to have images or photographs of themselves included may indicate this on the Consent form provided.

I hope to have at least one follow up focus group interview with five to six missionary participants. Follow up interviews will be arranged by mutual agreement. If you do not wish to be involved in follow-up interviews or observation you may say so at any time during the research process.

The interviews are all voluntary. Interviewees can end the interview at any time and refuse to answer any questions. I would like to record all interviews for future reference while proceeding with this study. However, participants are entitled to ask that the interview not be recorded or that the recording device be turned off at any point during the interview. Participants can also request a transcript of the recording and may make changes to their statements at any time before 1 February 2012 when the data will be analysed. Participants may also withdraw without question from the interview or request that their information be removed from the research process at any time before 1 February 2012 when the data will be analysed. Participants can request a summary, or a copy of the research after completion in July 2012, by indicating this on the Consent form, or by contacting me.

These interviews will form the basis of my research project and will be put into a written report on a confidential basis. All personally identifying features (including institutional affiliation) will be removed unless I am given permission to use your name. All material collected will be kept confidential. No other person besides me and my supervisor, Dr Andrew McGregor, will see the results of the interviews. All material gained from interviews will held in a password-protected file at Victoria University of Wellington, and destroyed 6 months after the completion of the research unless you would like them returned to you. The thesis will be submitted for marking to the School of Geography, Environment and Earth Sciences and deposited in the University Library. It is intended that one or more articles may be submitted for publication in scholarly journals. 


\section{APPENDIX B: PARTICIPANT CONSENT FORM}

\section{Exploring Missionary identity and development in Bangladesh}

You have been asked to take part in a research study by Anna Thompson from the School of Geography, Environment and Earth Sciences at Victoria University of Wellington (VUW), New Zealand. This research involves exploring what it means to be a Christian missionary, how mission is defined and how faith shapes missionary activities in Bangladesh. The results of this study will be included in Anna Thompson's Master's thesis. It is also anticipated that the findings of the study could be written up for publication.

Please read the Participation Information Sheet, and ask questions about anything you do not understand, before deciding whether or not to participate.

\section{PERSONAL DECLARATION:}

I have been given and have understood an explanation of this research project. I understand that I may stop the interview or ask for the recording to be stopped at any point during the interview without having to give reasons. I understand that I may withdraw myself (or any information I have provided) from this project at any point before data is analysed on 1 February 2012, without having to give reasons and without penalty. Any concerns or questions I had have been answered to my satisfaction, and I agree to participate in this study. I understand that I will have an opportunity to read all transcripts of the interview/s. I am 18 years of age or over.

I understand that any information I provide will be kept confidential to the researcher and the supervisor. Any published results will not use my name or the name of my employers/organisation, and no opinions will be attributed to me in any way that will identify me, unless I give permission to do so. I understand that the recording of interviews will be destroyed 6 months after the end of the project unless I indicate that I would like them returned to me. I also understand that I have the opportunity to obtain a summary of the research, and a copy of the final thesis after completion of the research.

Please tick the appropriate boxes:

1. $\square$ I give permission for interviews with me to be recorded.

2. I give permission for my opinions to be recognised by:

My name $\quad \square$ the following alternative name

3. $\square$ I agree to the use of images and photographs that may identify me being included in thesis and in publications and presentations

4. $\square$ I would like to be sent a summary of the research at the end of the project.

5. $\square$ I would like the recordings of my interviews returned to me at the end of the project.

6. $\square$ I would like to receive a PDF version of the final Thesis.

If you ticked the boxes 3,4 , or 5 please provide contact details below.

Name of Participant:

Signature of Participant: Date: 


\section{APPENDIX C: PROPOSED INTERVIEW QUESTIONS}

Do you think of yourself as a missionary? If not, why not? How do you define/understand Christian mission? What is the most important part of being a missionary, for you? What is a 'good missionary'?

What do you/your organisation do? What is your work here in Bangladesh, and what other things do you do that you consider part of being a missionary?

Why do you do this? Why are you a missionary? Why did you come to Bangladesh?

Do you think that 'development' and mission interact? Should they interact? How? Differences? Similarities?

If you are happy talking about it can you tell me how you are funded? (church, international, government, individual donations)?

Is there anything else you have been reflecting on or would like to talk about, from your experience? Is it useful for you to discuss this? 